
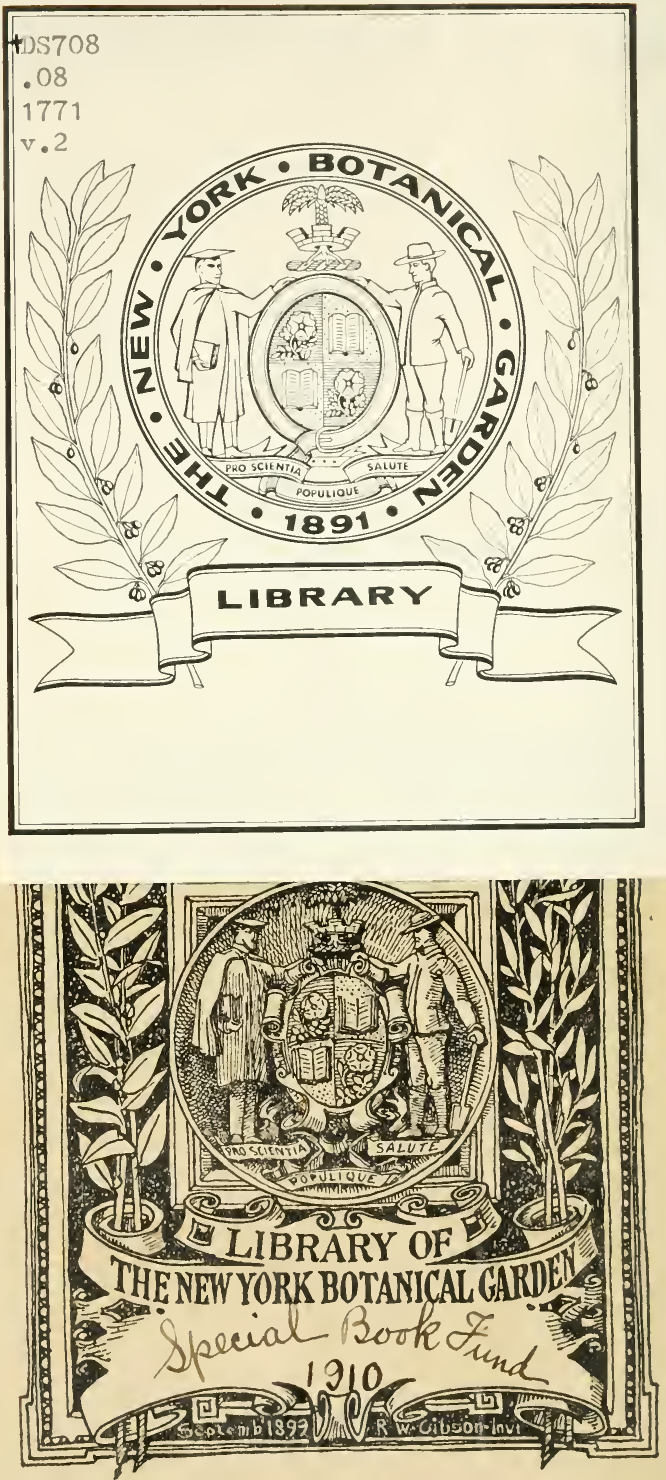
5 



\section{$\begin{array}{llllll}\mathbf{V} & \mathbf{O} & \mathbf{Y} & \mathrm{A} & \mathrm{G} & \mathrm{E}\end{array}$}

T 0

\section{CHINA ANंD THE EAST INDIES,}

By $P$ E T E R O S B E C K,

RECTOR OF HASLOEF and WOXTORP, Member of the ACADEMY of STOCK HOLM, and of the SOCIETY OF UPSAL.

Together with A VOYAGE TO SURATTE;

$$
\text { By O L O F T, O REE N, }
$$

Chaplain of the Gothic Lion East Indiaman.

AN D

An Account of the CHINESE HUSBANDRY,

By Captain CHARLES GUSTAVUS ECKEBERG.

Tranflated from the GERMAN,

By JOHN REINHOLD FORSTER, F.A.S.

To which are added,

A Faunula and Filora Sinensis. V O L. II.

$$
\begin{array}{lllllll}
L & O & N & D & O & N,-
\end{array}
$$

Printed for B E N J A M I N W H I TE, at Horace's Head, in Fleet-ftreet. 


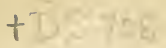

$$
\begin{aligned}
& \text { (1) }
\end{aligned}
$$

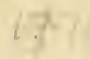

$$
\begin{aligned}
& \text { - in wis }
\end{aligned}
$$

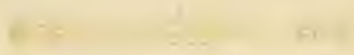

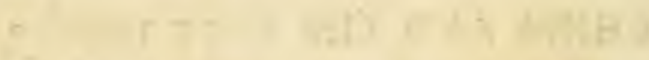

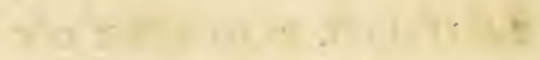

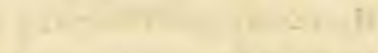

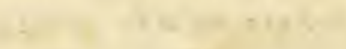

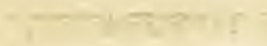

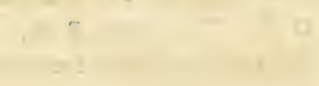

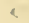

$$
\begin{aligned}
& 7+2-1
\end{aligned}
$$

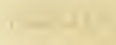

$$
\begin{aligned}
& \begin{array}{l}
+ \\
+12 \\
+1
\end{array}
\end{aligned}
$$




\section{[}

\section{PETER OSBEGK'S}

\section{VOYAGE to CHINA.}

\section{October $24^{\text {th. }}$.}

TO-DAY I had another opportunity of 1 gathering plants near the watering. place:

Utricularia bifida [Tab. iii. fig. 2. a. b.] is a plant which looks very like our Swedift Utricularia vulgaris, but is fomewhat lefs. It grew in a valley in low fwampy ground, which however was not under water. As this plant had never been found before, I immediately drew up the following defcription: the caly.s is diphyllous: the foliola are oval, excavated, perfiftent: the corolla is ringent: the upperVo L.. II. 
lip is without incifions, oval, with reflected fides: the lowcr-lip is bifid, with deflected fides: the mouth is elevated: the nectarium conical: the capfule is egg-hhaped, and is dehifcent on the fides: the feeds are numerous: the plant in length is an hand's breadth: the root is fibrous and ramofe: the bractea are very fmall, oval, alternate: the peduncles grow alternately, and are compreffed: the flowers are fmall and yellow. It grows in wet places.

Plyyllantbus Niuri. The corolla is monopetalous, fexdentated, and white: the capfule is fixlocular: the root is fibrous: the fem is erected, undivided.

Hypericum Chinenfe differs from the Hypericum quadrangulum in the following particulars: Hypericum Chinenfe is much lefs, and lies on the ground. The fegments of the calyx have five veins, and are fomewhat longer than the flowers: the petals are narrow, lanceolated, excavated, erect, and of the length of the calyx: the I 3 filaments are filiform: the anthere globofe and very fmall: the germen is egg-haped, and with three filiform fyli : the figma is obtufe; and the capfule egg-hhaped: the feeds are numcrous, oblong, and fmall: the leaves are oval, coming out of the ftem from the angles: the peduncles bear but one 


\section{H I N A. 175 I.}

flower each, and grow at the top of the falk. It is found on fteep hills.

Scutellaria Indica grew in thady places, on an earthen wall, and was a great rarity. I have never found it any where elfe. On a curfory view it looks very like the Glecoma be deracea, Ground-ivy, which in our apothecaries fhops is fold by the name of Hedera terreftris. This plant not yet being defcribed by any botanift, I have here drawn up an accurate defcription of it :

The caly $\%$ is divided into two equal fegments, very fhort; it has behind an elevated, fpoonlike, tharp-pointed fcale, whofe margins are bent down, and clofe after the flower is withered: the corolla is ringent: the tube is cylindrical, or almoft quadrangular: the upper-lip is trifid: the middlemoft lacinia is emarginated, and inflated : the lacinice on the fides bend towards each other, and cover the ftamina with their fides which are bent inwards: the lowerlip is divided into four lacinia, expanded, excavated, and the lacinice on the fides dotted: the four famina are covered by the upper-lip: two of them are fhorter, and are the length of the fylus: the antherce are round and fhort: the germen is divided into four parts: the fylus

$\mathrm{B}_{2}$ 
is filiform, and the ftigma is entire: the four feeds are uncovered, fmall, and round. The plant lies on the ground, and has the appearance of ground-ivy (Glecoma bederacea): the root is frbrous: the ftalk is quadrangular, fomewhat rough, ramofe: the branches are compofite, and ftand at the top: the flowers grow on fhort peduncles, commonly by pairs: the bractca are fimall, lanceolated, oval: the leaves are oppofite, cordated, oval, crenated, petiolated, pilofe, except the fmall leaves coming from the corners of the greater ones, which are kidney-fhaped. I found in a fhady place no more than two fingle plants of this kind. The Cbinefe call it Tim-gam--aa.

Hedyotis berbacea? the calyx is quadrifid, fhort, with pointed, reflected fegments : the corolla is monopetalous: the tube is cylindrical, very thort: the limbus is quinquefid, cylindrical below, bearded in the infide, with equal reflected lacinice: the four filaments are fhorter than the corolla, bearded, and reft on the incifions between the lacinie: the antbere are of equal breadth, of the length of the filaments, erect, fimple: the germen is almoft round, and below the corolla: the flylus is filiform, bearded, longer than the corolla : the fig- 


\section{H I N A.' 175 I.}

5

ma is double, club-thaped, trigonal. It grows on dry places.

Croton febifcrum. A little tree, which the Chinefe call $O-k a \cdot 0$, and at firft fight looks like an afp or afpin (Populus tremula). The male flower. The calyx is very fmall, bidentated: the corolla is wanting: the filaments are numerous, very thort: the anthere are double, almoft round, erected: the female flowers fit below the male ones, fix, feven, or more together, on common peduncles: the calyx is trifid, with pointed, erected fegments : the germen is oval : the three fyli are fomewhat reflected. The tree is very branchy, and as high as a man: the branches are round, fmooth, with buds of leaves: the leaves are alternate, fmooth, and like thofe of the Black Poplar-tree (Populus nigra): on the inferior fide they are fomewhat woolly, and have long, filiform, foftly ftriated petioli, or foot-ftalks. The lcaves have about twelve veins, which on the lower fide are fronger: the flowers are yellow, fand at the top; the male and female in a corymbus. This tree is to be met with on the fhores and ditches, though but feldom. Du Halde fays, the fruit of the Candle-tree is covered with an hard, lignous, fmooth, triangular thell; thefe thel's contain three little feeds of the fize of

B 3 peafe, 
peafe, each of which is furrounded with a white tallow-like fkin. W'hen the fruit is ripe, the fhell opens into three parts. For my part, I have never feen the fruit of the Croton, and therefore cannot be fure whether it is the fame tree of which the Lappt-yacks candles are faid to be made, as I have been told.

Chryfanthemum Indicum grew here and there, both on the mountains and on the walls of Canton, and likewife before the rooms of the Chinefe in flower-pots. The flowers not only ferve as an ornament, but are ufed inftead of rea. The Cbinefe call it Kock-fa.

Lattfa is the Chinefe name of a little tree which here grew on a high field, and looked like the rero-tree; but the leaves were ornamented on the inferior fide with white ftripes, running length-ways as in Pinus balfamea, or the Phalaris picta, known among us. It feemed to be Taxus nucifera Fi, vulgo Kajo. Kamph. Aman. 8 I4.

Briza' elegans? Spicis oblongis, valvulis carinatis, an exceeding fine grafs, which grew near the higheft plantations.

Dapone Indica. The calyx is wanting : the corolla is quadrifid: the lacinice are all of an 


\section{H I N A. I75I.}

equal breadth : the eight filiform famina are as long as the corolla, or the pifillum: the antberce are fmall, almoft round, and ftand on the fides: the germen is oval and rough: the fylus pointed: the figma entire : the brancles are round and axillar: the leaves are oppofite, petiolated, oblong-oval, fmooth, without incifion. The plant is of a fpan's length. It grows in high places.

\section{October the 25 th.}

THis day I took a journey to the watering. place, after the fermon, and from thence proceeded to the European burying-place, on the Danifs Ifland. I obferved the following na. tural curiofities:

Celofia argentea grew as a weed on the pota: toe fields.

I found tendrils lying every where in the low grounds hereabouts; they were like the Hydrocotyle Afiatica, but had no parts of fructification.

Adiantum flabellulatum. The falk (ftipos) is triquetrous, and ftriated on one fide: the franches are alternate: the leaves are unequal,

$$
\text { B } 4
$$


and form femicircles, quadrants, or octogons. The Clsinefe call it Siag mao quang.

Sambucus nigra looked like a fhrub, and was wreathed with the Cafytha.

A fort of moss, which was like our Lichen parietarius, lay dry on the hills by the fide of the plantations, but without the parts of fruc. tification.

A climbing plant with white berries was found on the Chinefe Pine-trees and ftones.

Hedyfarum maculatum on the hills.

- Hedyfarum (Ayracifolium) foliis fimplicibus cordato orbiculetis, retufis, Jupra glabris.

Holcus (latifolius) glumis trifloris, flofculo primo inermi, duabus margine aculeatis, foliis fubouatis. The falk is fmooth, and fcarce a foot high : the leaves are very broad, and almoft oval, with broad ftriped vagine: the panicula confifts of fimple branches like rods : the fowcrs ftand a! ternate, fingle, on hair-like peduncles: each flower is oblong and oval: the caly $x$ is fhorter than the flower, and confilts of two thins, and contains three flowers; of thefe the firft is fmooth, but the fecond and 


\section{H I N A. $175^{\circ}$.}

third are armed on the upper margin with crooked fpines.

Ko-fu, or Yam ko-fua, is the name which the Cbinefe gave to the great trees which grew near the plantations.

Palamm is the name of the leaves with which they covered their fruit bafkets.

Paulinia Afiatica was planted round the wall of a little fpot of ground. If this fhrub would grow in our country, it would make the beft hedges about our gardens, \& c. for in cafe any one fhould attempt to pafs through it, he would fcarce efcape without marks in his hands and cloaths from the fharp-pointed hamated thorns of this plant.

Olom-fo was the name given to a certain great tree. Its leaves were pinnated, fmooth, with oppofite foliola. A rofin came out of the tree, very much like the Gum arabick.

Polypodium varium.

Tricbomanes Clbinenfe.

Smilax China. This little fhrub grew but fparingly on this illand. Its root is univerfally hyown amongft us by the name of Radiv Clbinat, 
Cbine, and is annually brought from thence to Sweden in great quantities.

Smilax Sajjaparilla.

Saccharum Cbinenfe grows in the river like reeds. The Cbinefe call it Mao.

\section{The 29th of October.}

Quong-Fong, or Chine fe wafps (bees), often tormented us in great numbers, both in town and on board the fhip. It is Apis levis flavo fulvoque varia, abdomine, lineis iranfverfis undatis nigris.

I rook another journey to Canton to day. Near the firft cuftom-houfe grew Hibifcus mutabilis, which began to bloffom in the beginning of this month, and ftill continued to do fo. Enquiring for the name of this tree, I was anfwered, that it was called $F a$, which feemed a much too general dencmination, for $F_{a}$ denotes a flower. It is poffible that the Cbinefe have impofed upon me on this and many other occafions; but it is indifferent which is the true Clinefe name of a plant, fince we can do better with the Latin name. 
The calyx is like the head of a hat fqueezed together. On the entrance towards the houfe a fine Pomegranate-trce was planted, which was then in fruit. Both this and Rofa Indica, together with Rubus parvifolius, are tokens of the tafte this nation has for all forts of plants to adorn their habitations. You will fcarce meet with a family either in town or in the boats without fome herbs or trees in flowerpots, if not for ufe, yet for the fake of pleafure.

Kow-fonn is the Chincfe name of white long roots, of the thicknefs of Parfneps, the extremes of which had been cut off, and with which a fampane that paffed by was quite filled. They were tied into bunches with their enfiform leaves, and were offered to fale.

The Feaft of Lanthorns began this day, and was to be celebrated for three fucceflive nights, in honour of the god of fire, Fa-kong, which is done in the following manner: Many hundred lanthorns made of fkins were fo hung up, that they together made a fort of arches over the flreet; and befides thetc, many chandeliers in form of trees were made ufe of. Before the houfes on the outfide they had placed 
great paper-men, and horfes; commonly all the rooms in the houfes were flung open, and were every where illuminated. The muficians were in the rooms towards the ftreet, and played on inftruments which $I$ had never before heard. I was met by three facrificing priefts, who walked about in the houfe facrificing and burning incenfe. They were cloathed in long, wide, red robes, and wore high caps. The Clbinefe faid that they thus annually prayed for fecurity againft fire.

\section{The 3 oth of October.}

BAsEela rubra, which is here called Tandfoy, climbed up the walls of the factory of the merchant Soyon-quas. It had flowers and fruits at prefent. The fpots which the berries make in white linen are very hard to be got out.

\section{November 2d.}

${ }^{2}$ Sitra (Chincunfis) palpcbrâ infcriorc purpureâ. (Diff. Cbin. Lagerftr. 6.) The Cbinefe call it fiow-kay-konn. This bird was fomewhat

a This bird is not in the Syft. Nat. Edit. I2.

longer 


\section{H I N A. I75I.}

longer than a gold-finch. It fometimes fung a little, and was beautifully marked. A couple of thefe were fold here at half a piaftre. Its defcription is as follows: the back from head to. tail is dark, ferrugineous, with bluifh downs: the breaft and the belly are white; but toward the throat it is black: the bill and bead are black : the creft confifts of black feathers, and is longer than the bill: near the eyes is an oblong, finall, fcarlet fpot, and clofe to this a large one as white as fnow: from the temples to the throat runs a black line: the cbin (mentum) and the tbroat itfelf are white, but this white is encompaffed with black, except a white line in the middle of the breaft, which joins the white of the throat with the fnowy breal : the uropygium is yellow at the top: the nineteen quill-featbers have ferrugineous dark coverts: the twelve blackifh tail-feathers have white tops: the feet have four toes: the bindtoe is the length of the toes on the fides: of the fore-toes the middlemoft is the longeft.

THIs bird is kept in China more for the rake of its beauty, than for its fine fong. It is fed with boiled rice. 


\section{The $3 \mathrm{~d}$ of November.}

WE dined to-day with the merchant Tantin$q u a$, at whofe houfe tea was packing up for us. Here again the high value which the $\mathrm{Cbi}$ nefe fet upon flowers planted for ornament was obfervable. Before the dining-room was a fine garden, laid out with ftones, and in it was:

Luaifa, a tree about fix yards high, with fmall, white, fweet-fcented flowers, whereof three or four were in one Involucrum. The tree belongs to the Tetrandria clafs.

Laan-fa, a tree with yellow, corymbofe flowers, and pinnated leaves.

Dracana ferrea, the iron-trec ${ }^{b}$, which in

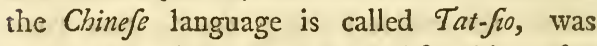
higher than the preceding; and for this reafon I could not reach the flowers, which were at the top in bunches. The branches were fup-

b (Draccena ferrea, Linn. Syft. Nat. Ed. I 2. p. 246.) D. S. remarks that it is called Afparagus terminalis, in Species Plantar. and Terminalis alba by Rumph. Am. vol. iv. p. 79. tab. 34, but Linnous, in his new fystem, page aforementioned, calls that fpecies of Apparagus, Dracana terminalis. $\mathrm{F}$. 
ported by Bamboo fticks. What follows is its defcription: the calyx is monophyllous, bidentated: the corolla is monopetalous: its tube filiform, Thorter than the limbus; which is fexfid, with oblong lacinice, of which the exterior ones are fomewhat larger, and include the filaments; which are fhorter than the corol$l a$, and faftened at the bafe of the limbus: the antherce are oblong, narrow, erected : the pifillum is longer than the flaments: the germen is oval, and refts on the tube of the corolla : the ftylus runs into a point : the figma is entire, and inflected. The tree is more than twice the height of a man. The ftem is very ramofe, uncovered, rough: the branches are bent, naked, and have bunches of leaves at their ends: the leaves are lanceolated, fwordfhaped, only grow at the top, are numerous, reddifh, with ftriated foot-ftalks, or with revoluted margins : the flowers grow at the top, in form of Corymbi; each of them is fmall and red.

Epidendron enfffolium was planted in flowerpots. Its flowers had an exceeding fine fcent, efpecially after fun-fet.

Cbryfantbemum Indicum. About 30 plants of this fpecies were put into each flower-pot.

They 
I6 OSBECK'S VOYAGE.

They were difpofed in circles one about another, and eacl had a little Bamboo ftick to fupport it. The flowers were as large as thofe of the Tagetcs patula, commonly called Flos Africanus, white, double, or full, and each by itfelf, as well as all together, like a round bruf.

IN the corner of the garden was fomething which refembled an altar, compored of pebbles; on it was placed a little vafe, in which fome fmall ftones and fome rubbifh lay, which were all as wet as if they were continually immerfed in water. I did not learn its ufe; but perhaps it ferved to water the Bamboo-tree, which ftood between the ftones and the wall.

\section{The 7 th of November.}

I TENT by water to Sto-namm, but was forced to take the interpreter, or comprador, with me; who greatly circumfcribed my pleafure by being in fuch hafte to return. I found no new things, except

Nyctanthes birfuta.

Lycium baruarum, a thrub on the road.

Fufica 
Fu Jiaa repens, in a ditch, with a Lemna.

Carpefum abrotanoides, in a fhady place.

\section{The gth of Noucmbor.}

Camellia Faponica, (its Chinefe name is Fo-kai), a tree which was carried about and expofed to fale in the ftreets. I bought one of a blind man in the ftreet, which had fine double white and red flowers. But by further obferving it in my room, I found that the flowers were taken from another tree, and one calyx was fo neatly fixed in the other with nails of Bamboo, that I fhould fcarce have found it out, if the flowers had not begun to wither. The tree itfelf had only buds, but no open flowers. I learned from this inftance, that whoever will deal with the Chinefe, muft make ufe of his utmoft circumfpection; and even then muft run the rifk of being cheated.

I HAD a mind to fee the fituation of the environs of the fuburbs, in that part where I had not yet been; and was forced to go by myfelf for want of company. As foon as I had paffed the ufual trading ftreats, the boys

VaL. II. gather- 
gathered about me in thoufands, throwing fand, ftones, and dirt at me, and fhouted all together Akia, aque ya, quailo; and with this mulic they followed me through the whole town. At the end of the fuburbs begins a plantation with Sagittaria bulbis oblongis clofe to the houfes. A large, low, clayey field was employed in the culture of this plant. And as I ftopped here, and only gathered now and then a plant, my difagreeable company ftopped their noife, efpecially when I turned to them. Here was no road which carried direaly into the country, nor did I venture any farther; but returned whence I came. However, in the afternoon, I went out of town in a palan$k i n$, by this means avoiding my difagreeable forenoon companions. Returning again, I went on foot about the wall of Eanton, on the fide from the country, and there found Cisryfantbemum Indicum, Urtica nivea, little clumps of Fern; and other plants between the ftones, but they were out of my reach.

WHEN we came to the firft city-gate, towards the ficle of the Europcan burying-place, a mandarin, with a whip in his hand, joined us to accompany us about the city. Near this gate was a Clbinefe inn, where brandy and tea 


\section{Ci H I N A. 175 I.}

were fold. The people ftood by the fide of the round-houfe on the wall, and ftared at us; however, we got by without hurt, though not without fear, becaufe we remembered that a perfon was fome time before pelted with ftones from this very place. When we approached nearer to the fuburbs, we every where, and almoft clore up to the wall, found houfes; they were all full of men, and efpecially children and youths, who fang their old fong, of which they were put in mind by the grown people, if they did not begin it themfelves. Yet we likewife found an old reverend man who had more fenfe than the others, and mare his children or grandchildren greet uscivilly. The perfons of rank in this country teach their children from their earlieft years the dictates of virtue and honefty, and fpare no expences towards a good education: but the common fort of people train their children up with their dogs; for which reafon neither of them can bear ftrangers. We afterwards paffed by many gates, and over a little caral into a lane along the fide of the wall, in which Cbina-oranges, Plaintains, Cbina-olives, or Packia, and many other fruits, were fold. An intolerable ftench, and the noife and clamour of the populace, obliged us to make hate to the Sroediß $\beta$ faciory.

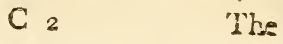




\section{The I 7 th of November.}

TO-DAY I went to the fhip, and afterwards to the Danifh Ifland, on which fome Clsinese oyfter-hells had been thrown.

OF thefe thells I have feen an entire wall of a garden made, on the other fide of the river near Canton. The mells were in fubftance like ours; but larger, longer, and narrower at one end. The Cbinefe call thiem $\mathrm{O}-a$, or o-ba.

\section{The 2 ift of Novembir.}

Crovdy $\mathrm{ky}$, and drizzling rain.

On account of the fands which are in the river, the European fhips are obliged to go fomewhat lower towards the mouth of the river, before they take in their full cargoe; which we did to-day, after we had taken a pilot on board. We now anchored at South. Haver. 
The $22 \mathrm{~d}$ of November.

IN the fore-noon we went on further againft the tide, as far as the firft bank, or bear, as our failors call the fands. In the afternoon we had an agreeable country, with villages and woods, on our left; but along the river fide a narrow rice-field, and in the river two fmall illands. We failed very near the moft outward of the two, by means of the fampanes keeping always at an equal diftance: but we afterwards tteered off from it, as if we were going full upon a little houfe on the right, furrounded with trees: but before we had quite reached the middle of the river, we went ftrait on again, and were faid to have paffed the firft fand. Somewhat nearer the Lioniower, (which we faw on our right) we approached the thore on the left hand, in expectation of another fand. We lay at anchor all night.

\section{The $23 \mathrm{~d}$ of November.}

Is the morning we paffed the Lion-tower. We kept near the fhore on the left, to efcape

$$
\text { c. } 3
$$


the third bank, which is faid to be 1500 fathoms in circumference. Having got paft the river which goes to Little Canton, by, the help of I 6 fampanes (whence the water for the voyage homeward is fetched with more conveniency than from Bocca Tiger, where the water-tubs muft be rolled a good way in deep clay), we anchored not far from the great rice-field on the left; where already two French, a Danifh, two Dutch, and two Englifh thips, were at anchor:

THE people brought an unpalatable fruit from the watering-place, which was almoft round, larger than an apple, and contained great dry rhomboidal feeds, which grew nar. rower towards tlie bottom.

\section{The $24^{\text {th }}$ of Novemler.}

J. lay in a very bad birth here, and were expored to ftorms and to the cold air of the fea. Here we learnt that though the Cbinefe winter is but jut cold enough to produce an ice in the night, which is melted away in the day-time; yet the air about this feafon is yery tharp and piercing. 


\section{H I N A. 175 I.}

WE were now almoft as far again from Canton as in our firft ftation, at leait we were forced to pay a ciouble price in order to go thither. It was not poffible to go on fhore, on account of the great rice-fields, which occupied both fides of the river. In thefe rice-fields we every day faw ducks, and great long-legged white birds, but they were too far of for us to know their gemus. I rifited the Danifls thip, which was full laden, and had a far greater number of men than curs: the cabbin of the cliaplain, Lawrence Hercks, was one of the fineft and largent in the fhip. This perfon told me, that the Danift fea chaplains had, befides their fettled income, a confiderable contribution from the Rhip's company; and that accordingly their income was reckoned treble to that of the Swociflo chaplains. But they are fufficiently rewarded in our country if they can gain the love of their audience.

CHINEse turtle-dowes were bought for our return, and we kept them alive a good while aboard the fhip. Their characters are thefe: the bill is red: the upper jarv is the longeft, and lias a protuberance like a nail: the

$$
\text { C. } 4 \text { tongue }
$$




\section{OSBECK'S VOYAGE.}

iongue is triangular: the body and the wings below are ferrugineous: the bend and the neck are darker at the top: the back is marked near the wings with reddilh yellow fpots; but a little farther on it is red, verging towards black, where likewife two black lines run over the edges of the feathers: they have twentytwo quil-featbers whofe coverts change from green to gold; and eleven feathers in the tail.

\section{The 27th of November.}

To-DAY the Danifb hip failed for Europe. The Danes baften their departure, but lofe more time in the refrehments they take on their voyage, Cn their going to the Indies they choofe an agreeable port which our hips pals by; for they fop at the Cape of Good Hope, where they can purchafe the finet wines at low prices, befides the pleafure of vifiting a people who adorn their bodies with what would ?urn our ftomachs but to hear of: I mean the Hottentot girls, who twift raw guts about their legs to thew that they are beauties; and have nany other frange cuftoms, as travellers relate.

For want of other diverfion, I defcribed the following filtes, which were caught here:

Clupgea 


\section{H I N A. 1751 .}

Clupea Myfus: the membrana branchioftega has ten rays: the dorfal-fin is oblong, directly oppofite to the ventral-fins, and has thirtcen rays, of which the firt is the fhorteft: the pectoral-fins have feventeen rays, of which the feven upper ones are divided, and of fuch a length as to reach beyond the anus: the ventral-fins are oval, and have feven rays: the anal-fin has eighty-fix linear rays, and reaches from above the middle of the fill to the tail: the tail is fharpened, and has thirteen or fourteen rays : on the belly are 43 little teeth (denticuli): the body is narrow, compreffed, the hind-part decreafes very much : the upper jaw is the longeft, and ends in a prominent, ferrated beak, fhaped like a fword: the mout $b$ is in the form of a rhombus, and large. The fith is of a fpan's length, and white.

Perca Cbinenfis. The dorfal-fin reaches from the head almoft to the rail, is lower in the middle, and has thirty-fix rays, of which the ten firft are fpinofe, and the ninth is the fhorteit, and unarmed: the pectoral-fins have eighteen rays: the ventral-fins have fix unarmed rays: the anal-fin has ten rays, of which the two firft are fpinofe: the tail is oval, and has ferenteen rays: the mouth is oblong, the teeth 
26 OSBECK'S VOYAGE.

teeth are in the branclioficga. The fin has the outward appearance of the Perca fluviati. lis, but is lefs. The linea lateralis is bent. 'T he fifh is pale yellow: the lower jaw is fhorter than the upper.

Clupea Torifa. The membrana brancbiofacga has feven rays: the lingle dorfal-jin takes up the middle, and has 16 rays, of which the laft is double the length of the reft: the pectoralfins have fourteen rays: the ventral-fins liave feven rays, and are very fmall: the anal-fin has twenty-four rays; it does not begin quite in the middle, and reaches to the tail : the tail is furcated, and has 24 rays: the moutb is large, oblong: the lower-jaw is the longent, and dotted with black towards the top: the body is narrow, white: the denticuli on the belly are thirty in number.

The Ilandarin ffo, Sparus nobilis. The membrana branclioftega has three rays: the firft dorfal-fin has four, and the other nine rays: the pectoral-fins have fixteen rays: the rentralfins have fix rays: the anal fin has twelve, and the tail twenty-four rays. The length of the fin is hardly a foot: the hody is narrow, the fiales are white: the licad is egr-fhaped, and round: 


\section{H I NA. I751.}

round: the mouth fmall, globofe: the upperjaw is the longet: the eyes are fmall, near the upper margin of the moutb: the opercula brancbioftega confint of three bones.

Snow-white Dolplbins (Delplbinus Cbinenfis) tumbled about the fhip; but at a diftance they feemed in nothing different from the common fpecies, except in the white colour.

THE next day I again went to Canton.

\section{The IIth of December.}

Turs day, which is the fixth in the eleven month of the Cbinefe, or Sbienglbio, is very remarkable among them; if it is clear, it foretells a good year to come ; but when beginning with rain, they expect a fterility of crop. They bring facrifices to their idols, in order to be preferved from the dearth. It was fine weather all the day along, whence they prophecied a plentiful year.

\section{The I 7 th of December.}

In the forenoon I buried the Purfer Hubin, who died yefterday of the dyfentery. He was 
born in France, and brought up to the Roman Gatholic religion : he afterwards embraced the Lubleran religion at Gotbenburgh, and poffeffed great knowledge in both religions. He kept his good-humour on to a great age; and indeed it never forfook him to his death. In the afternoon I gave him the facrament, and immediately after he departed peaceably. To bury him, we paffed the river to a peninfula, and afterwards through a great canal, over which many bridgुes were made, till we at laf arrived at the burying-place, which had been bought for him in an inclofed place on the left. The Chincfe took fix tale for the grave. Near the burying-place was a number of coffins above the ground, as I have already remarked elfewhere.

THE mob was very riotous, and we made hafte to finith the fervice. Afterwards we went to the atorementioned parode, which lies on the other fide of the canal, in Honang. In the fields hereabouts were little holes here and there, in which feeds were put and covered over with alhes. A fpot, on which according to the account of the Chinefe a medicinal kerb was planted, was covered with mats, which were expanded a yard bigh above the ground. 
ground. This plant was as yet fo fmall, that I could not tell whether it was or was not the Amarantbus trifis. I was fhewn, but at a great diftance, how the high fields about $B x c$ ca Tiger were green with a plant out of whofe feeds the Cbinefe prefs their oil, which they call loam. It is faid they have a trick of boiling the feed before they fell it. It is moft probably Sefamum. We vifited their fail-clotiz manufacture of bambou fplints on which bambou leaves are laid. They call it Tiock-yee. The ropes are likewife made of bambou threads. Here alfo was a place where both great and fmall boats were built ; and rudders, and feveral mills to grind rice, \&c. were made. On the fields the Poa Malabarica was growing; and near the pales and enclofures a fort of reed, which the Cbinefe call Luta, and looks like Arundo donax. I at laft got for a pialtre twenty-five kinds of pot-herbs.

\section{The 2 ift of December.}

I AGAIN returned to the fhip, and met the thip chaplain Toreen in the banchal ; he had buried a failor on the French Ifland, who died of a pain in his fide aboard our thip. 


\section{$3^{\circ}$ \\ OSBECK'S VOYAGE.}

SCOLOPENDRA pedibus utrinque viginti was here found near the banchal.

THE fhips prepared for their voyage home, except the Dutch commodore fhip, which was to ftay till March, and bring the fhips accounts into order.

The $25^{\text {th }}$ of Decenber.

CleAR, calm weather.

Oysters, which the Cbinefe called Hao, were fold quite frefh to us. It was a different fpecies from thofe whofe fhells have been aforementioned; they were rounder, five or fix, or more of them grew together, and are extremely difficult to open: for the purpofe of opening, the Cbinefe always have a proper piece of iron about them when they fell Oyfer Some of them were faftened to great ftones, and on them the Sertularia conferva formis was faftened. It was plainly vifible that they came out of a clayey bottom. They were very like our oyfters, but larger, in particular the animal in them; which the Chinefe take

$$
\text { out, }
$$




\section{II I N A. 1751 .}

out, put into water, and thus fell them to their countrymen without the hell.

Sparus Chinen/is, or the Little mandarin fifh, which is like the Sarfe (Cyprinus Erytbropbtalmus) were here caught in plenty, and by the Cbinefe called Fiya-yo. The following is its defcription: the membrana brancbioffega has five rays: the firt dorfal-fin has four fimple rays, of which the hiridmolt is quite foft; this fin has a lanceolated appendage on each fide: the fecond dorfal-fin is not armed, has eleven divided rays, and is of the length of the former: the pectoral-fins have it räys: the ventral-fins have fix rays, they have on both fides and in the midlle a foft appendage : the analfin has twelve rays: the tail is furcated, and has fixteen and more rays: the bead is narrow, flat; the moutb is fmall; it has no seeth: the eyes are near the mouth: the irides are white: the body is narrow, and lanceolated: the linea lateralis does not appear: the back is blue, and the reft white: the opercula branchiotega confift of two entire leaves. The length of the fin is fcarcely a fpan. The fcales are white rhombs. 


\section{2 \\ OSBECK'S VOYAGE.}

Gовтеs Eleotris, by the Chinefe called Sinnhas, is a greenifh, almoft round fill, which is fomewhat lefs than the preceding. The membrana brancbiofega has five rays: the dorfalfins have from fix to eleven rays: the pectoralfins have eighteen rays: the ventral-fins have eight rays, and are joined together into one infundibuliform fin: the entire tail has twelve rays : the body is almoft round, covered with little rhomboidal green fcales: the lower-jaw is thelongeft : the teeth are fixed in four rows in the mouth, are fmall and very fharp: the eyes are in the upper part of the head.

\section{The 27 th of December.}

IN the afternoon I went in the floop along the fhore, and paffed by the Lion-tower. Here was a great mountain on the thore where a reddifh fand-ftone appears, which is here fquared, and afterwards fent to Canton and other places hereabouts for coffins, flags, ftonedykes, walls, \&c. The workmen had erected a number of little houfes in the quarry, which made the mountain on the fide towards the fea look like a little town. The mountain was 


\section{H I N A. I75 I。}

covered with Chinefe (as an ant-hill is with ants) from the top to the bottom. At the fummit was a little redoubt, and paved roads led towards the fhore. On the fields where rice had been growing, fome thallow furrows were made to keep the filhes back in them when the water ran off. I would have landed with the floop, but it was out of my power. One might have made a pretty collection of folfils here. We were aftonifhed to fee that the Cbinefe, who had put their nets into the water, hot continually without aiming at any thing: but upon enquiry we were told that they were forced to watch their fifheries continually, and to frighten away the ducks, who would elfe empty the nets fooner than men could. I never faw fuch fearlefs and numerous flights of ducks as here : one flight after another came, notwithftanding the noife that was made on all fides, and endeavoured to fettle near the nets ; but were always hindered in the above manner: thefe wild ducks were not quite like ours, as will appear from the following defcription:

Anas (Cbinenfis) regione oculorum maris vin ridi. The male: the wings have about twenty-eight quill-feathers, of which the firft ten VOL. II. 


\section{4 \\ OSBECK'S VOYAGE.}

are the longeft, and afh-coloured; their upper margin is black, and the ground grey: the four or five next are afh-coloured, with green upper margins and white bordered tops: the four hindmoft ones are longer than thofe in the middle, and afh-coloured: the greater coverts are white on the margins of the upper fide; the reft are afh-coloured: the eleven tail-feathers go tapering, have white borders, and are grey at the bottom: the bill is of a blackilh grey, and foft: the upper mandible covers the lower: the teeth in the margin of the lower mandible are lamellated: the head is brown like the chin: a white line paffes below the eyes: all about the eyes is green: the neck and the fore part of the back are covered with white feathers, fpotted with black: the hind. molt part of the back and the uropygium are afh-coloured: the featbers which cover the upper part of the neck are white, with black fpots: the black feathers covering the uropygium have white borders: the breaft and the belly are white, and fpotted with black backwards: the feet and legs are afh-coloured: the three forc-toes are joined; the bind-toe is free: the membranes have crenated edges: the femalc is covered at the top with black featliers, but at the extremities with reddifh white ones; it 


\section{H I N A. 1751 .}

is white below, with black fpots: the chin is white: the bead and all about the eyes is of a whitifh grey: the quill and tail-featbers are almot the fame as in the male. The Cbinefe call this fort of ducks Hina- $a$. There is another fort of ducks to be met with at Canton, which is called Kong*ao, but this I have not feen.

THE bird which the Clbincle make ufe of for fining is reprefented in feveral voyages, and is here called Lou-foo ${ }^{a}$; but no author has given a full defcription of it: I offered a reafonable reward to any one who would procure me fuch a bird for a flhort time; but in vain, though this way of fining is faid to be ufed in Macao. According to the reprefentations of this bird in the books of travellers, it muft be very like the Man of War (Pelecanus aqui. lus). They defcribe the finhery to be performed in the following manner: the filherman faftens an iron ring about the bird's neck, fo that it may not fwallow any fifhes: on the ring is a rope with which the bird is held: As foon as a fith is obferved about the boat, the fifherm man toffes the bird into the water, who imme-

- In the Ambaffade de la C. O. des Provinces unies, p. 172. t. 173. it is called Loura. 


\section{OSBECK'S VOYAGE.}

diately does its duty, and then is pulled up with the fifh in its bill. This method of fin. ing is very expenfive. Its price is fettled, and is faid to amount very often to fifty tale. Befides this, the filherman pays a certain fum of money as an annual contribution.

\section{752 . \\ The ift of fanuary.}

Hiving taken in our cargoe in porcellane, tea, filk, foc. according to the following account, and provided ourfelves with water for our return as far as fava, we yet took in this day fome Cloinefe potatoes, turneps, yams, carrots, leeks, cabbages, and other garden ftuff.

\section{Bill of Lading. \\ Teas.}

$1,030,64^{2}$ pounds of Bobea-tca, in $=885$ cheits. $96,589 \mathrm{lb}$. Congo-tea, in $107 \mathrm{I}$ large, and 288 leffer chefts. 
$67,388 \mathrm{lb}$. Soatchoun-tea, in 573 large and 1367 leffer cheits.

17,205 lb. Pecko-tea, in 323 chefts. 6,670 lb. Bing-tea, in 119 chefts. 7,930 lb. of Hyfon-Skinn-tea, in 140 chelts. 2,206 lb. of Hyfon-tca, in 31 tubs. $3,557 \mathrm{lb}$. of feveral forts of tea, in 1720 canifters.

\section{Silk Stuffs.}

961 Pieces of poifies damafk.

67 Pieces of ditto, of two colours.

143 Pieces of damafk for furniture.

673 Pieces of fattin.

I5 Pieces of fattin, of two colours.

I6 Pieces of ditio, coloured flowers.

68 I Pieces of padiafoy.

192 Pieces of gorgoron.

I,291 Pieces of taffety.

16 Pieces of lampaffes.

5,319 Picces of yeliow cotton Nankin ituffs. $5,047 \mathrm{lb}$. of raw filk, in 33 chefts.

\section{Sundries.}

$35,314 \mathrm{lb}$. of Galanga roots.

$6,359 \mathrm{lb}$. of China roots.

$2,165 \mathrm{lb}$. of mother of pearl.

D? 
$6,325 \mathrm{lb}$. of thin canes for hoops.

$10,709 \mathrm{lb}$. of fagoe.

$4,17 \mathrm{I} \mathrm{lb}$ of rhubarb, in 24 chefts.

$9,314 \mathrm{lb}$. of painted paper.

I,250 Pieces of flowers, Eंc.

3,400 round jettoons of mother of pearl,

140 in each fet.

62 ditto, 10 in each fet.

108 japaned play-boxes, with mother of pearl jettoons.

18 japaned tablets, or boxes for a toilet.

10 japaned tablets.

6 tons of arrack.

\section{Porcellane.}

322 chefts, 70 tubs, 52 leffer chents, and 9 I9 packs.

THE fhip was twenty-one feet ten inches behind, and twenty feet five inches before, in the water.

\section{The $4^{\text {th }}$ of fanuary.}

After a ftay of four months and ten days in Cbsina, our thip and the other Swedift thip 


\section{O F F C. H I N A. 1752. 39}

began their voyage home. Every one leaped for joy, and my $\mathcal{T}_{e a-} / \mathrm{hrub}$, which ftood in a pot, fell upon the deck during the firing of the canons, and was thrown over-board without my knowledge, after I had nurfed and taken care of it a long while on board the fhip. Thus I faw my hopes of bringing a growing tea-tree to my countrymen at an end; a pleafure which no one in Europe has been able as yet to feel, notwithftanding all poffible care and expences. Some have brought tea-nuts as they get them from the Chinefe; but in cafe they could get them frefl (which I very much doubt), they are fpoiled on the voyage: others have bought tea-Ahrubs in pots, which they commonly get in flower juft before their departure from Cbina, but they withered about the Cape of Good Hope.

If the Europeans were themfelves allowed to go into the tea-woods, and to gather there fuch feeds as are neither too dry nor unripe, nor boiled, they might be kept in any thing; but without this they can only get fhrubs (in the factories) in little flower pots, with too little earth, or with fuch as is not fit for their tender roots. The tea-hhrub would doubtlefs habituate itfelf to our climate; but if we want 
40 OSBECK'S VOYAGE.

to receive the benefit of it, we fhould firft learn to prepare tea, which may turn out more difficult than we have hitherto imagined; for fome prepare tea fo ill eren in Clsina, that it does not tafte fo well as one of our Swedifts teas. But, fuppofing we knew the beft method of drying it, we could never fell a pound of homemade tea fo cheap as the Cluinefe tea, while Sweden has not proportionably the fame number of induftrious inhabitants as Cbina ${ }^{b}$.

After we had failed a good way, we faw a great mouth of the river opening into the fea on the right; but we failed to Bocca Tiger, whofe caftles were fituated on the naked hills of two iflands, about which only fome trees were planted. They were exactly oppofite to each other. That which is neareft to the con. tinent is the higheft.

Is the evening we caft our anchor along with a Frencb fhip bound for Macro.

b Dr. Limneus has had fince (the $3 \mathrm{~d}$ of Oztober, 1763 ,) a fine tea-fhrub brought him from China, by (aptain Carl. Gufaro. Eckeberg, which is, as far as we know, the only pne in Exrope. F. 


\section{O F F C H N A. 1752. 41}

\section{The $5^{\text {th }}$ of Fanuary.}

Is the morning we weighed our anchor, and foon after paffed the fands at Bocca Tiger, where we found ground at four fathoms depth, in high water.

\section{The 6th of Fanuary,}

Cloudy fky. Freh gale.

The pilot left us. We directed our courfe from the great Ladrone Ifland, to the Englifh Sand, and afterwards to the ifland of Zapata, which the Portugue $e$ call a Laft on account of its form.

The Monfoons are conftant winds which blow for half a year together in the Eaft Indian fea, and they were now N.E. and fometimes varied a degree or fo on either fide. They continue N. E. all Novcmber, December, Fanuary, February, and March, with dry weather. In April and September they turn about, and at that time the molt frightful ftorms blow from pll fides. The worft of all is that which the 


\section{OSBECK'S VOYAGE.}

Cbinese call Taifun; for (as I have been told by a Swede who had been in the Eaft Indies) it continues often for twenty-four hours together with fuch violence, that nobody is able to walk up and down, but is as it were confined to his place. At leaft it is always reckoned the worft hurricane which can poffibly happen on a voyage to the Eaft Indies. In May, Fune, ouly, and Auguft, the wind is always fouthern hereabouts, and generally attended with rain.

\section{The 8 th of Fanuary, $15^{\circ} \cdot 45^{\prime}$. N. L.}

Tre Englif Sand had thirty-fix fathoms of water. The ground was red fand, mixed with corals.

The roth of famuary, $10^{\circ} \cdot 3^{8^{\prime}}$. N. L.

Changeable weather, fometimes clear, fometimes cloudy. The wind blew hard, and the fea was very boifterous. About four o'clock in the afternoon we had the illand of Zapata weft.

STERNA nigra, fronte albicante, caudâ cunciformi, (Cloin. Lager/ir. 9.) was here caught. It 


\section{O F F C H I N A. 1752.}

had twenty-feven quill-feathers and eleven tailfeathers, and was of the fize of a jack-daw.

\section{The IIth of fanuary, $8^{\circ} .1 I^{\prime}$. N. I.}

Generaliy clear fky. Frefh gale.

WE thought we paffed Polo Eandor in the morning dawn, at leaft we did not fee it this time. (Polo is the Indian name of an ifland.)

\section{The $15^{\text {th }}$ of fanuary.}

Cloudy, changeable, rainy weather, which was looked upon as very uncommon in this la. titude.

THE Ifle of Lingen (which is exactly under the equator) we paffed the night before. Though this place is very hot, yet it is not fufficient to produce men without parents, as a Pagan writer from the inand of Wack-zuack relates. See Bayeri Comment. de Orig. Sin. 278. Polo Toya was on our right in the forenoon. At noon we had the feven iflands on our left, two of which are higher than the reft. Near the firft high inland there feemed 
to be another fmall one: but perhaps it is not feparated from the other.

\section{The 16 th of Fanuary.}

Generally rainy and inconftant weather.

The laft night we anchored in the Straits of Banka, near the hores of Sumatra, where the river Palimbanka difcharges itfelf in the fea, after we had, the night before, pafied by Monopin, or the laft high mountain on the illand of Banka, oppofite Sumatra.

FREDERICK-Henry, a rock hidden under the water, (which has formerly been the ruin of many thips) was paffed very happily.

Arout noon we faw the third (but counting from Canton the firft) Cape on Sumatra, covered with the fineft and farceft trees, fo that it looked as if the whole country confifted of a cut garden-hedge. The mot outward were probably Indian canes, and the reft fome kinds of $P$ alm trees. The country appeared finer at this difance than I am able to defcribe. The peonle were defcribed to me as affaffins; and 


\section{OF F C H I N $A . \quad 1752 . \quad 45$}

and it was believed that in every bufh were crocodiles and other hurtful animals: but if I thould have met lions and tigers, I mur neverthelefs have wifhed myfelf on thore, had it been but for an hour. But we fteered towards Salari, a mountain on Banka. And after we had likewife paffed the fecond neck of land, we caft anchors at night.

\section{The i 7 th of Fanuary'.}

To-DAY, excepting the morning, we had fine clear weather, but little wind. We began to fail very early, as did the other fhips, which we left near China, but joined here again. At noon we paffed the inle of Lucipara: the paffage for great fhips between Sumatra and this ifland is very inconvenient, becaufe there is but three and a half fathom of water on the fand bank; but as foon as you are got by, and have Lucipara (I fpeal as coming from Cbina) N. E. you are then out of danger.

\section{The i8th of Jamuary.}

AfTer eight o'clock in the morning ive had the Two Brothers on the left, quite near us. 
46 OSBECK'S VOYAGE.

This is the name of two iflands corered with trees, between which the water is faid to be fo low, that not even a little boat can pafs.

\section{WE here obferved confiderable breakers.}

Aвour four o'clock in the afternoon we had Toppers Hat and the high woody thore of Bantam on the left; but fomewhat farther on, about fix o'clock, we had the Hat of Brabant, a little woody rock, on the fame hand: and directly oppofite to it, on our right, a long, narrow ifland, which is called Acrofs the Way.

\section{The igth of fanuary.}

After a fortnight's royage from the $I_{a}$. drones, we anchored about noon in the New. Bay, the ufual harbour; and we took as much water from fava as would fuffice for the whole voyage. In the afternoon I went in a boat on fhore near the place whence we took in water. It is difficult to reach the fhore, becaufe the ground is fo full of corals (Millepora Favanenfis), that we were obliged to leare the boat a good way behind us, and the people got out and waded up to their breafts in water, and with difficulty carried me to the fhore on 
their fhoulders. The country here is very high, and the water which comes hither from the fens in the wood runs roaring into the fea. The failors fix a leathern fpout which reaches to the boat, and thus fill their tubs. The water itfelf was pretty good, and in my opinion the beft I ever drank on my voyage. The foil on the fhore confifts of a fine whiting grey fand, in which all forts of corals, fuch as $M a$ drepora organum, and Star-fones (Millepora), and likewife Cowries (Cyprea) and other thells, were to be met with. But I left all thefe and went into the foreft with the carpenter, who looked for fome timber for his purpofes. We kept clofe together, becaufe we were in danger of not meeting again in cafe we had feparated. The foreft was fo clofe, that we paffed through with great difficulty; and the cries of birds, and lizards, and other noifes, would not permit us to call to each other. In fome places it was fo wet, that I followed my companion with reluctance, for it rained about this time every night and forenoon, and fometimes even all the day long. The exceffive high but flender trees make the foreft dark; and a quantity of Palm trees of fix yards high, whofe leaves were prickly, tore our cloaths, nay even the 
$4^{8}$ OSBECK'S VOYAGE.

fkin off our hands and faces. This little $P$ allith tree is

Caryota (urons Linn. ') frondibus bipinnatis, aculcatis, foliolis cunciformibus, rotundato pramorfis. I did not fee the parts of fructification, and therefore am not quite certain of the genus. The frondes are, as in the Caryota, bipinnated and whitifh below: the lcavcs are oppofite, almoft oval, plicated; the upper margin as it were lacerated : the petioli are covered with many oppofite, hamated fpines, not only at the beginning of the foliola, but even at the fecond and third pair of them.

Another fort of little Palin trees ${ }^{\text {(Calamus }}$ Rotang Linn.) was likewife in our road. The fem was without branches, had a crown at top, and was every where befet with ftraight fpines. This is the true Indian cane, which was not vifible on the outfide; but the bark being taken off, difcovered the fmooth ftick, which has no marks of fpines on the bark, and is exactly like thofe which the Dutch fell to us, keeping this matter very fecret, left: travellers going by fhould take as many canes as they want out of thefe woods. Sumatra is faid to be the place where mort of thefe fticks

c. Favanica. Oßbeck.

a Palma Baculus. Ofteck. grow. 


\section{J A V A. 1752 .}

grow. I took two to try them, but left them behind during my voyage. Such plants ought to be chofen as are of a proper growth between two joints, fuitable to the fafhionable length of canes as they are then worn: but fuch are fcarce. I do not know that any one before has given an account of the Indian canes while they are growing.

AfTer we had got a good way in this foreft, which is reckoned fo dangerous on account of tigers and other beafts of prey, my honeft carpenter, having tried feveral forts of wood, at laft met with a long naked ftem, which he felled. The timber of the tree was of a fine yellow colour, at leaft while it was newly cut. I looked for the parts of fructification in this felled tree; but thefe not appearing, I could not afcertain it. On its bark grew,

Iypnum Favanenfe.

Lichen pulverulentus viridis et albus, and

Afplcnium Nidus ; this formed a for: of cup in the angles between the branches, in which the birds made their nefts.

Calamus Rotang (varictas) is a little flender trec without branches or twigs, wiliding about

VOL. II.

$\mathrm{E}$ the 


\section{0 \\ OSBECK'S VOYAGE.}

the high trees near it, even to their tops, and tying them as it were together. I faw here a tree with eight branches, each of which (being of the thicknefs of a finger) bent down and formed roots, by a natural direction, unaffifed by art. Thefe branches were befet with eniform leaves; Dut I found neither flower. nor fruit on the tree.

$T_{H}=$ Sio-lock-tao of the Cbinese was twifted rol nd the trees. On an unknown tree, which had no flowers at that time, I faw a fruit both in colour and frape like Hips.

Little $P$ alm trees, whofe fruit was like the Nux vomica, with green or brown fhells, grew not far from the fhore. In the fame place I found a plant refembling the $A \%$. pinia racemofa, together with many other uncommon trees and herbs, which I could not afcertain, becaufe I could find no parts of fructification.

EPTDEIDRUM amabile grew on the branches of trees on the thore. This plant hath great white odoriferous flowers, fuch as I never obferved before. I had this plant lying in my room for fome days together; but the fowers 


\section{J A V A. 1752。 5I}

aid not wither, and filled it with the moft agreeable fmell. On the I/le of Ternate none but princeffes are allowed to wear this precious flower, which is but too fcarce ${ }^{2}$. The thape of it is as follows:

The corolla is pentapetalous: the three exterior petals are oblong : the two interior ones are roundifi oval, expanded; the upper lip of the nectarium is fhorter and inflected; the lower is pinnatifid and inflected; it has four lacinic, of which the two greater ones are obtufe at the bottom, but the two others are very fmall and fharp: the gland at the bottom of the nectarium is bifid, yellow, with little red dots: the point of the lower-lip has two fliform appendages: the roots are numerous, foft, flat, and ftick to the barks of trees. It has only three leaves, which ftand at the root, are undivided, and without nerves, almoft. falcated : the falk is undivided: the flowers are alternate at the top.

Pavetra Indica, a little tree, which was not far off the watering-place.

Jasmines a areum grew below the high trees.

- Rumpl, Uerb. Amb. Angræcum alb. majus.

E. 2

HIBISCUS 
Hibiscus populneus, a tree with fine great flowers, ftood below the aforementioned plant. Its leaves were fomewhat foft beneath, and had falks which were reflected: the bractece are round: the outward calyx is fhort, divided into eleven parts ; the inner is quinquefid, $f_{1}$ times longer than the outer: its leaves are lanceolated.

THE thore was almoft every where covered with corals, efpecially Madrepores and Coralorgans; befides thefe, petrified fpunges (wirhout ftalks) and thells were to be met with. But the trees (which in moft places hung over the water) did not afford us a free paffage.

THE Hermit crab, or Cancer Eremita Yavanica, was found in a hell. Irs left clare was larger than the right, but it is however a different fpecies from our common Cancer bernbardus.

Lichen marimus, Cluf. Hift. p. cer. was in plenty on the thore.

Nignt obliged me to break off this agreeable employment fooner than I could have wifhed: 


\section{J A V A. 1752.}

wifhed: and having feen the trees with many branches, from which a number of roots hing down perpendicularly, near the wateringplace, I was forced to go on board again with the boat. Here I found two fcarce fifhes, which a friend of mine had got for me, that I might put them into fpirits. They were :

Clsatodon faxatilis? a yellowith flounderlike fin, with broad black tranfverfal fafcia: the fingle dorfal-f $n$ is low, and reaches to the tail : its thirteen foremoft rays are prickly, the remaining twenty-fix are longer, have a black ftripe below, and likewife black tops: the pectoral-fins have fixteen rays: the ventralfins have fix rays: the three firft rays of the anal-fin are prickly, but the other twenty have black fpots, which taken together make a narrow ftripe: the tail is entire, and has twenty rays: the body is broad and compreffed, with quadrangular feales: the opercula bran. cbioft. are fcaly.

Sparus Spinus, was like a fort of dried fifh which we bought at Canton for our voyage. The dorfal-fin reaches from the head to the tail, and has twenty-four rays, of which the thirteen foremoft are prickly and thorter: the pectoral-fins have fifteen rays: the ventral-fins 
54 OSBECK'S VOYAGI.

have fire rays, of which the two extreme ones are prickly: the anal-fin begins at the middle of the finh, and goes to the tail, and has fifteen rays, of which the firt feven are prickly : the tail is bifid, and has eighteen rays: the fidcs are grey, except towards the belly, and have a bent lateral line: the belly is white: the lips are foft: the length of the body is a fpan.

The favenefe brought the following things to fell on beard our hip : apes, fhells, Turkift corn, and

Java deer (Cervus faranicus). The upper primary tceth are wanting: of the inferior eight lower the two middle ones are three times broader at the ends than the reft: the three cutting teeth on the fides are pointed: the atpper-jazu has a fharp canine tooth on each fide, which is of the length of the cutting teeth; therefore this animal is not Capra perpuffilla, Mus. Reg. Succ. p. I2. I have feen the buck and the doe, neither of which had horns, though our failors affured me they have feen them with horns. Of the nine grinders the fix inner ones are cuouble, and the three exterior ones are laciniated $\left(l_{0} \mathrm{at}^{\mathrm{b}}\right.$ ). This

b The feet of this fpecies of deer are fometimes fet in filver, and ufed as tobacco-ftoppers. 
Ipecies of deer equals a new-born lamb in fize. The colour is a reddifh brown. The buck (whofe head I have now been defcribing) is larger than the doe, and has white ftripes on his fides which run longitudinally. They lived upon frefh blades of rice, which we fowed in pots for that purpofe.

IT has been faid that Parrot fifhes were to be found hereabouts, but I never was fo happy as to get one.

\section{The 2 oth of January.}

A HEAVY rain kept me from going on fhore in the forenoon; but in the afternoon I went to the little uninhabited illand called Nero Iland, (fee vol. i. p. I 31.) which was a good way off our thip, and near Fava. We landed at a little brook, in which our people wafhed their linen. Formerly, as the fhip Ritterboufe was on her voyage to China the came too late to Fava, and the contrary monfoon being already fet in, the was obliged to ftay here till the wind changed. During that time the failors built huts on this ifland, and cut the year of our LoR D 1743 on a good many trees, as we

$$
\text { E } 4 \text { obferved }
$$


56 OSBLCK'S VOYAGE.

obferved in feveral places. The bottom of the fea, which was at the depth of two fathoms, more or lefs, was full of tharp ramofe corals. On the thore were to be met with coral-fones, coral-organs, bippuris faxea, and feveral flells, moft of which were fpoiled and worn away by the water. Among the thells were principally cypraas, barpago 5 cornibus, (Strombus Cbiragra Linn.) and others.

I ADVANCED fomewhat further on the ifland, and faw the Plantain.tree (Mufa Paradifiaca) growing fpontancouly, and the monkeys jumping from one tree to another, as fquirrels do in our commtry. The continual cracking noife which I heard was, as our people faid, made by a fort of lizards, of which I could not procure one fpecimen.

Several butterfies fiew about me; but my eyes were fixed upon the Flora. I went along lie fhore becaufe the woods appeared too cronded for me, and obferved the following fcarce trees:

Sopliona alopecuroicies, a little tree with 2 foft ftem.

Morinda cirrifolia.

Guettarda 


$$
\text { J A V A. I752. }
$$

Guettarda Speciofa, a ramofe tree with odoriferous flowers. The calyx is cylindrical, with an almoft entire margin : the corolla is monopetalous : the tube cylindrical, longer than the calyx: the limbus is divided into feven oblong lacinice: feven thort filaments: the antherae are longer than the filaments, and of equal thicknefs: the germen is almoft round: the fylus is filiform, longer than the ftamina: the figma is thaped almoft like an egg. The fruit is nearly round, and contains many nuts: the branches of the tree are quadrangular, with dots, and horfe-fhoe-like fpots.

Lobelia Plumierii is a little tree which ftood on the fhore, and had the following characters : the calyx is very fhort, quinquefid: the fegments of equal breadth, and equidiftant from each other: the corolla is monopetalous, on one fide fplit open down to the bottom, four times longer than the calyx : the tube is cylindrical, hairy in the infide, longer than the limbus, hiant on one fide: the limbus is quinquefid, hairy, with lanceolated lacinia, which are curled up on the margin; the middlemoft is the thickeft: the five filaments are filiform, faftened to the receptaculum, and of the length of the piffillum: the antberce are ob- 


\section{OSBECK'S VOYAGE.}

long, narrow, and furround the figma: the germen is egg-haped, pentagonal, compreffed, and below the flower: the fylus cylindrical, of the length of the filaments, bent fo as to incline through the incifions of the corolla: the figma is fcyphiform, and hairy : the mut is almoft round, and of the fize of a pea: the tree has wrinkled and hanging branches, and grows on the fea-thore. The leaves are inverted-oval, mucronated, fmooth, without incifions, almoft without nerves, petiolated: the falks of the leaves are of equal thicknefs all the way: the flowers arc white, and axillar.

Crinum Afiaticum with its glorious white flowers, enriched the fandy thore. I brought both the plant itfelf in a flower pot, and the bulbs or roots of it preferved in fand, to Sweden.

Corypha umbraculifera was likewife growing here. Of this the great round fans are made, with which the mufquitoes or gnats are expelled in Cbina.

Cordia Myxa flowered on the fhore: the leaves are oval, petiolated, without incifions, alternate: the trce is very ramofe: the branches 


\section{J A V A. 1752。}

are wrinkled, round: the flowers are yellow, and ftand in corymbi at the top.

Pbytolocca Favanica, a large tree on the fhore, whofe leaves are fmooth, but its branches villofe: the calyx is wanting: the corolla is monopetalous, quinquefid: the fegments are oval, very fmall: the ten filaments are bent at the top, faftened to the receptacle, and longer than the corolla: the anthere are almoit round: the tree is very ramofe: the branches and leaf-falks are woolly: the leaves are broad, lanceolated, petiolated, without incifions, fmooth, and have feven nerves: the flowers are corymbofe and fmall.

Flagellaria Indica. Its boughs twine about other trees, as the ftem is no thicker than a tobacco-pipe, but generally fome fathoms long : the calyx is monopetalous, bidentated, very fhort, on the outfide of the flower: the corolla is monopetalous, oval, globofe, and clofed up: the filaments are fhort, filiform, faftened to the receptacle, the antberce are oblong, erect, and longer than the filaments: the fylus is fingle: the figma obtufe: the flowers grow at the extremities in bunches like grapes (Corymbi): the falk is round, ramofe: 
60 OSBECK'S VOYAGE.

the leaves are alternate, arundinaceous, fcarce vifibly petiolated, and end in tendrils.

Convolvulus pes capra grew in the fand by the water fide.

Chiton marginibus dorfi fpinofis was found in the fea by a failor.

WE weighed anchor; but were forced by the contrary wind to caft again not far from the firft place, namely near

Prince Ifland, which is larger than New 7/land. It has been faid, that a petty prince, mafter of this ifland, lives on it, and that he formerly ufed to vifit the fhips, and was fatisfied with triling prefents. In the afternoon we went on thore near a little river, where we could take in water, which however is nor fo good as that in fava. I did not obferve any mountains here, nor on New Ifland. On the river we found a little hut, which our people beliered to be built by fome Englifhmen. We preffed into the woods, but were forced to turn back to the fhore, where the great trees (which hung quite over the water) likewife greatly oppofed my paffage. On thofe trees I found two fpecies of ferns, one of which 


\section{J A V A. 1752 .}

was Polypodium Parafiticum. But I loft both while I was carried back over the river. On the trees grew :

Lichen pulverulentus viridis et albus, and under it,

Boletus caulefcens, coriaceus, pileo sinereo et rubro.

\section{Calla Favanica foliis lanceolatis, and}

Anomum Zerumbet, or wild ginger; of which I made the following defcription: the calyx is wanting, inftead of it are two eggnaped bractea: the corolla is dipetalous: the two flaments are hort, filiform: the anthera. are long, of equal breadth, and faftened to the fide of the corolla: the germen is cylindri$\mathrm{cal}$ and fhort: the ftylus filiform, longer than the famina : the figma is oblong: the capfula is egg-fhaped, oblong, fiat on the inner fide, obtufe on the outer, triangular, multilocular, full of juice, white: the Jeeds are egg-Ihaped, narrow, red, covered, and about fix in number: the plant grows on fhady thores: the roct is like that of ginger, and has long fibres: the falk is round with obtufe bractea, which stick very clofe to it: the flowers and fruit make an oval catkin (amentum): the radical 


\section{OSBECK'S VOYAGE.}

leaf is pinnated, with lanceolated, entire $f \circ$ liola.

Mamme Afiatica, a great tree, generally ftands on the fhore and hangs orer the water. Almoft every tree, particularly this, was full of great black ants, for which reafon I could not eafily mount the branches; however I was forced to do fo, before I could make the following defcription:

The calyx is biphyllous, with great, oval, concave, perfiftent leaves, which include the corolla; this confifts of four oval, clofed petals, which are deciduous at the fame time with the filaments, and are like them longer 'than the calyx: the filaments are numerous, filiform, bent, frorter than the fylus, but longer than the corolla and the calyx, and at the bottom joined with the petals: the antherce are almoft round and fmall: the germen is below the corolla; it is obovated: the ftylus is very long: the figma pointed: the tree is very ramofe, and bends down with its top: the ittle brancbes are round: the lcaves grow in bunches at the extremity of the little branches; they are entire, without ftalks, imooth, carnofe or pulpy, fomewhat crenated 


$$
\text { J A V A. } 175^{2} \text {. }
$$

at the top, and have alternate tranfverfal nerves.

Hernandia fonora. Of this great remarkable tree I only faw two on the fhore. It affords a fure antidote againt poifon, if you either put its fmall roots on the wourds, or eat them; as was difcovered to Rumplius by a caprive woman in the war between the People of Macafar and the Dutch in the year I667. The foldiers of the former always carry this root about them, as a remedy againft wounds with poifonous arrows. The leaves of this tree are thick and fmooth. Another tree like this, which likewife grew here, had not fuch thick and fmooth leaves.

Melia Parafitica, a little plant of fcarce a finger's length, grew on the ftems of the trees. It is fo fcarce, that, as far as I know, it has never been noticed before. The calyx is monophyllous, tridentated, cylindrical, and is half the length of the corolla: the corolla is monopetalous, cylindrical, quinquefid, with oblong lacinis: the neclarium is bell-haped, obtufe on the margin: on the inner fide of the margin ten extremely fmall filaments are fituated: the antherce are almont quadrangular: the 


\section{OSBECK'S VOYAGE.}

the germen is cylindrical, pentagonal: the $\beta y$. lus is pointed below, and villofe : the figmi elevated : the flowers grow in the form of a bunch of grapes. The plant had little leaves.

After fo thort a vifit on this excellent ifle, I was forced to go on board again, to wait for a fair wind that might forward us on our royage.

The $22 \mathrm{~d}$ of Fanuary, $8^{\circ} \cdot 34^{\circ}$. S. L.

RAIN。

EARLY in the morning we failed from Prince Ifand, and in the afternoon left Fava out of fight.

\section{The 2 th of fanuary.}

VERY rainy weather. A'lmoft calm. We caught two bonets (Scomber Pelamis). Its two pectoral-fins were put upon a filhing-hook, to reprefent a likenefs of a flying-fifh, which the bonet often purfues with all its might, and frequentiy jumps up very high above the water. 


\section{J A A A. $175^{\circ}$.}

The 27 th of Fanuary, $10^{\circ} \cdot 3^{8^{\prime}}$. S. L.

CLoudy and rainy weather.

Camellia, which I had in a pot, began to open its flower buds. Obf. Gemize awillares, conico-imbricata, foliola gemmee ovata, obtusa alterna, imbricata. Foliatio equitans.

The 28 th of Fanuary, $12^{\circ} \cdot 35^{\circ}$. S. I.

Almost all the day fine weather; and contrary wind.

Fou R dolphins (Coryphana Hippurus) appeared near the thip. This fif looks like the falmon, but has a colour which changes from blue to green in the water. It was thought to be the beft filh that we had caught during the royage.

\section{The 29 th of Fanuary, $13^{\circ}$. S. L.}

CLEar weather. The trade-wind was juft now beginning.

VOL. II.

$F^{\prime}$

$\mathrm{W}_{\mathrm{w}}$ 
66 OSBECK'S VOYAGE。

We difcovered a whale in our neighbourhood, by its throwing up the water.

The ${ }_{3}$ d of February, $15^{\circ} \cdot 44^{\prime}$. S. L.

Larva feneftrata, which I found the $3^{\text {th }}$ of Septeniber of the patt year on the Croton febiferum, and which changed a fecond time the next following night, now got out of its grave, where it had been near five months, and became Phalana Atlas Linn. as far as I could fee, though it was very ill haped.

Dermestes fubrotunda atra was bufy in eating the Deontfai-feed which I bought in China. As foon as it had eaten the kernel, the empty hufk juft fitted it: and accordingly I found fome time after each of them dead in its hufk.

The 6th of February, $18^{\circ} .50^{\circ}$. S. L.

Clear weather. Frefh gale.

I HAD no thermometer; but the leaves of Camellia and of the Batatas thewed that it was colder 


$$
\text { J A.V A. } 1752 \text {. }
$$

colder here than in Cbina. The accounts of feamen of a greater degree of cold at the fouth pole are pretty probable.

The 8th of February, $20^{\circ}: 47^{\prime}$. S. L.

A FLYING filh was now and then obferved in thele parts.

The I Ith of February, 22 $2^{\circ}$ 54'. S. L。

Clear weather. Temperate wind.

A Lizard had accompanied us from Canton, and was now found in a cabbin. It was Lacerta (Gbinenflis) cincrea, caudâ ancipiti, corpore paulo longiore, pedibus pentadactylis omnibus unguiculatis. The bead is flat, fhallow, oblong, even : the eyes are covered with a fkin, which at its tranfverfal opening has in the middle three gold coloured points oppofite to each other : the nofrils are round, largeft near the fnout, one on each fide: higher up are three lefs ones on each fide; and befides thefe are a good many lefs holes near the eyes : the teeth are numerous, fmall: the tongre is flat, obrufe, crenated in the middle; the body is

$$
\mathrm{F}=\text { broad, }
$$


broad, flat, with compreffed fides: the back is covered with blackin and whitifh elevations: the anus is tranfverfal : the tail is a little long- er than the body, has two fides, is compreffed, and has yellowin fcales, which are here and there on the fides: the fore and bind feet have five toes, are divided, and all the toes have hamated nails: the fifth toe is the fhorteft; all the toes are webbed below, and the webs fit crofs-ways: the upper fide of the body is afh coloured: the tail has eleven black fpots: the belly is white.

\section{The I $3^{\text {th }}$ of February, $24^{\circ} \cdot 7^{\prime}$. S. L.}

CLOUDY $\mathrm{kky}$, rainy, inconftant weather; and afterwards a uniform wind.

THE water which we had taken with us from Java was now full of fea Millepedes (Onifci), which fkipped about in it like young frogs.

The bulbs of the Crinum Afraticum, which I had put into a flower-pot at fava, now began to fhoot leaves. 
NEAR MADAGASCAR. 1752。69

The 17 th of February, $27^{\circ} \cdot 20^{\prime}$. S. L.

THE trade-wind ceafed to-day.

The 19th of February, $27^{\circ} \cdot 59^{\prime}$. S. L.

Clear, calm, fultry weather.

WE faw a whale; and a great dog-fifh paffed us, accompanied by four of the fifhes called pilots. We put half a chicken on our filhing-hook to catch the dog-fifh, but he was not hungry. In the dawn we faw fome porpoiffes.

The zoth of February, $28^{\circ} \cdot 3^{\prime}$. S. L.

$R_{\text {AIN }}$, but afterwards clear weather. Frefh wind.

\section{The $22 \mathrm{~d}$ of February, $29^{\circ} \cdot 49^{\prime}$, S. L.}

CLEAR weather, calm fea, moderate wind. We were now almoft directly oppofite Mada. gafcar.

$$
\text { F } 3 \text { The }
$$


go OSBECK'S VOYAGE.

The $23 \mathrm{~d}$ of February, $30^{\circ} .2^{\prime}$. S. L.

Clear and calm, toward the evening middling wind.

WE faw a dolphin near the hip. The wa. ter flowered, as it is ufually faid.

The 26 th of February, $29^{\circ} \cdot 52^{\prime}$. S. L.

Ciear weather. Contrary wind. It was cold in the morning.

A PIECE of wood with fome fea-grafs fwam by us.

Dolphins and porpoiffes gathered about the fhip.

The sth of $\operatorname{March}, 34^{\circ} \cdot 23^{\prime}$. S. L.

Towards evening we had thunder, lightning, and a great deal of rain.

THE flames, which have been mentioned before, fhewed themfelves now on all the 


\section{Near MADAGASCAR. 1752。 71}

three tops, at feven o'clock at night, when it was quite dark after the ftorm.

The 7 th of Marcl, $35^{\circ} \cdot 41^{\prime}$. S. L.

Good weather and wind, almoft calm in the afternoon.

Gannets (Pelccanus Bafanas Linn.) a fort of great white birds with long necks, and black tops of the wings, flew very high in the air. They are faid to be a fure mark of the fand at the Cape. About noon therefore we heaved the lead, but could not find ground. Some thought we were half a degree more to the fouth than appeared from the thip's reckoning.

THE next night about twelve we miffed a fecond mate, by calling the watch, whom we never faw again. It was thought that in his Ieep he fell into the fea through a port-hole.

\section{The 8th of March, $35^{\circ} \cdot 36^{\prime}$. S. L.}

$C_{L E A R}$ and almoft calm weather. Wind towards night.

$$
F_{4} \text { TH }
$$


THE porpoiffes were obferved here tumbling about in great numbers.

THE failors affirmed to me that the water flowered; when drawn up, fome-what in it looked like the roe of a fifh. I put fome of it by in a glafs, which at night gave a pale blue light, as if a million of little pearls lay clofe together, but the next day the light was gone. This matter fwam every where on the fea water, with which it was mixed. By day-light or candle-light it looked like a red, brown, thick, fago foup ; and when it was put on paper, it looked like little water-coloured fago grains, or fifh-roe; but I obferved no motion in them. The next morning every thing was funk to the bottom, and was curdled in the glafs; the water above it was quite clear, tho' fomewhat reddifh. I again put fome of it on paper, and found the grains water-coloured, but the paper was ftained with red fpots from the water,

THE next night we found ground with the lead at ninety fathoms. We had now been fixty-three days on our voyage from China. 
CAPE OF GOOD HOPE. I 752. 73

The roth of March, $33^{\circ} \cdot 13^{\prime}$. S. L.

A species of fea-weed fwam by our thip feveral times this afternoon, and was called Trumpet-reed by our failors a. It was above a yard and a half long, as thick as an Indian cane, and commonly fome ftalks were joined together: it formed as it were fly-flaps at the tops. My company on the fhip thought it came from the iflands weft of the Cape of Good Hope. When the failors fee Trumpet-weed on their voyage, they are pretty certain that the Cape is not above ten Szediff miles off.

The 17th of March, $28^{\circ} \cdot 34^{\prime}$. S. L.

\section{$\mathrm{C}_{\text {LeAR }}$ and calm weather.}

Besanties fwam on the water, and feemed to have a little bow-fhaped expanded fail on their backs. Thefe little animals change

2 Fucus (Maximus) caule tereti, fiftulofo, fimplici, flabello quafi terminato. An Fucus pavonicus? confer Trombas. G. M. A. V. V. L. Defcriptio itin. navalis in Ind. p. 5I. fig. mala. The leaves ftand at the top in bunches in two rows (difficba), and decreafe in fize by little and little. The ftalk had no leaves.

their 


\section{OSBECK'S VOY A GE.}

their colours. We caught a Befantie, but it was fmall and like the air-biadder of a filh. I had fcarce had it one day in fea-water, when it died, as might be obferved by the tentacula, which were diffolved into a llime; and it became as diftorted as thofe which are fometimes brought to Europe in Spani/h brandy. The defcription was made as foon as the animal was got out of the water, and is as follows:

Holotburia Phyfalis, Befanties. Rumph. Amboin. p. 49. The body is blown up, eggfhaped, tranfparent, with a yellowin green tail: the back is dark green, tharp; feven or more veins came out of it, which are yellowith red before: the bill is fpiral, and of a yellowinh-red colour: the tentacula are numerous, the fhortef are round, the middlemoft are the tendereft, tranfparent, and globofe at the top: the remaining tentacula are petiolated, and are longer than the reft; the one in the middle is thicker and much longer than the others, and dark blue: oppoite to thefe is a compounded blue elevation on the other fide, which is perhaps the fail which the animal expands in the fea. 


\section{CAPE OF GOOD HOPE. 1\%52.75}

The $25^{\text {th }}$ of $\operatorname{March}, 12^{\circ}$. 10'. S. L.

Cloudy, and afterwards clear weather.

Bonets (Scomber Pelamis) and Tunnys (Sconzber Thynnus) were now caught again. We ufed the Cuttle-fifh (Sepia Loligo) when we could get it, for a bait.

The Camellia, which I brought with me from China, now began to wither. The tea-(hrub, birds, and whatever is taken alive from China, commonly die in the latitude of the Cape of Good Hope, though it is the fame latitude as Spain, or rather nearer the æquator. I do not remember to have feen an entirely clear horizon on the fouth fide of the line.

The 3 oth of March, I $6^{\circ} .63^{\prime}$. S. L.

Almost clear; afterwards cloudy. Farourable wind.

A tropick bird flew very high as ufual hereabouts (Phaëton ethereus).

FLYING 
Flying fifhes and bonets were here in great numbers.

St. HeLENA, an illand belonging to the Englifh, came in fight of us. This ifland, according to the accounts we have, is faid to be near three $S w e d i f t s$ miles in circumference, and two in breadth. It is fituated in $15^{\circ} .56^{\prime}$. S. L. in the open fea, nearer to Africa than to America, about 200 Swedi/h miles from the neareft continent, and 600 leagues from the Gape of Good Hope. This illand, which is faid to be very agreeable, and to produce many Indian fruits, is very high, and mountainous on the fea-fide, for which reafon it can be feen at the difance of twenty leagues. It firft got its name from the Portugueze, who difcovered it in the year 150 r, on St. Helen's day. In the year I 600 the Englifh Eaft India company conquered it; and in the year 1672 the Dutch took it; but the Englifh have fince, 1673 , inhabited and fortified it; in 1701, two hundred families, moftly Englifh, were fettled on it.

YAMs (Diofcorea alata) are here, as I am told, planted and eaten inftead of bread by the poor. 


\section{ASCENSION ISLAND. I752. 77}

The navigators who will land at St. Helena, muft take care not to take their courfe too high, elfe they cannot reach the thore. The Swedift fhips generally ftop here to take in refrefhments, but we fteered ftrait on to the Ife of Afcenfion.

The $3^{\mathrm{d}}$ of April, $8^{\circ} .5^{\circ}$. S. I.

Clear. weather, middling wind.

TO-DAY and the day before we faw fing fifhes.

\section{The $4^{\text {th }}$ of April.}

Generally clear weather, and middling wind.

WE fteered from W. by N. to get the longitude of Afcenfion I/land, near which we failed in the forenoon; and at laft caft anchor in the Crofs-bay on the fame ifland, with twen. ty-four fathoms ground. 


\section{The 5th of April.}

THIR TY-one tortoifes were canght laft night.

IN the morning we went on thore on the tight fide of the Crofs-bay.

Afcenfion is an ifland which is fituated under the 8 th degree of latitude fouth of the rquator, and $8^{\circ} .24^{\circ}$. from St. Helena in the great Ethiopic Ocean, at a great diftance from the continent. Its length is reckoned above a Swedifh mile, and its breadth about half a Srvedifh mile. The Portugueze gave it this name becaufe they difcovered it on Afcenfionday. It is entirely uninhabited, and without woods. The largeft turtles, or fea-tortoifes, have their refidence on it, and are fometimes caught by hundreds in one night. The $E u$ ropean thips on their return from the Eaft Indies feldom fail by this ifland without going on thore to catch as many turtles as they want; but they never come in fight of it on their go. ing to thofe parts.

THE breakers on the thore are very violent, and would aftonin thofe who have never feen 


\section{ASCENSION ISLAND. 1952. 79}

the like before. A boat may be thrown a good way on the thore by them, as happened to the Swedifh Eaft India man the Gotbic Lion, whofe lloop, with fome men, was loft by this accident. The beft times to go on thore here are the firft months in the year, and as early in the morning as poffible. The thore for the greateft part is coyered with a fpecies of fand, which confifts of little elfe than broken thells, which form roundifh grains, larger or fmaller, fhining like pearls. This fand deferves to be called Shell-fand.

THE tortoifes creep out of the water upon the thell-fand which is loofe, and occupy fome fathoms in breadth upon the fhore, and often lie fo high that it is inconceivable how they can get up, fince it is troublefome even for men to get along, becaufe the fand flips under their feet, as if they walked upon peafe. As foon as a tortoife is got a little way from the water, the makes a round hole in the fand, in which the lays her eggs, and covers them over again with fand fo neatly that no one can find out where the has been. She afterwards gets into the water again, and is quite unconcerned about her young ones, which are hatched by the fun, and find the way to the fea as well 
as their mother, as foon as they have broken the fhell.

THE failors lurk at night on the fhore: and when a tortoife is crept up they turn it upon its back, with hooks (or, if they can, with their hands alone). In the latter cafe, they muft take care of the animal's mouth, for it bites of a finger with eafe; a misfortune which one of our failors experienced this time.

The tortoifes (Tefudo Mydas) are principally caught in two well-known bays; namely, in the Englifh-bay, where the taking them is faid to be attended with difficulties, and in the Crofs bay, on the right hand of which our captain had pitched his tent, on the fide of a mountain. In this mountain were two grottoes, or natural caves, at a little diftance from each other. In that which was next the fhore were feveral French and Englifh letters, of laft year, as advices to new-comers: the upper one is faid to have been the habitation of an Englifh fupercargo, who fome years ago was left here as a punifhment for a deteftable crime, with fome victuals, and an ax, to kill tortoifes, which he was forced to roaft by the heat of the fun on the mountains. It is likewife related 
ASCENSION ISLAND. 1752.81

lated that another nation afterwards helped him away.

I NEVER faw a more difagreeáble place in all the world than this illand. The climate in itfelf is hot, being fo near the line; but it would be tolerable if there were only fome trees under whofe thade one could take flielte.. The ifland has formerly had woods, as appears from feveral perfect petrefactions of branches of trees, and pieces of wood; bút in particular from a large petrified ftump. The illand is every where covered with ftories; they are not pebbles, but angulated pumiceftones, containing more or lefs iron. When you meet with a plain, it is covered between the ftones with a coarfe earth which looks like foot, and under it you meet with a reddifh fine fand. Here and there, efpecially on the more, are fome rocks. On the low places, where the water gathers during the rainy feafon, the earth was covered with a brown cruft, which would break like thin ice under one's feet. Here and there fome pieces of glimmer were found. A mineralogift might have collected many forts of ftones here, which ate not to be met with in other places. The heat is intolerable, and difables one from carrying Yox. II. 
any thing, it being difficult to fupport even the cloaths upon one's back, efpecially as walking is fo difficult. He who choofes to walk here muft wear hoes with thick foles; and muft notwithftanding expect to bring aching feet home at night. If the ftony Arabic is like this place, I pity thofe who are forced to wander through it.

There are feveral great hills on this ifland, which confift of the abovementioned earth and coarfe blackinh brown fand : in the latter lie larger or fmaller pumice-ftones ${ }^{b}$, which are dangerous to walk on, as by their rolling down one may break one's limbs.

As foon as we got on thore I went to a conic mountain a good way off the place where we landed. It was fteep, and of difficult accefs, becaufe with each ftep the fand and ftones rolled down: the heat increafed, and I was forced to reft feveral times. In my opinion, this mountain was quite as large as our Tïnnekulle. Neither on the fides, nor at the top, did I meet with one fingle plant; on the fummit, where the air was very cool, ftood a pole

Pumex cupri. Mai. Teff. 79. 2. three 
three fathoms long, which was provided with the neceflary ropes for hoifting a flag. Fron the pole hung two crofles, the lower of which was wooden, and had the letters I. N. R. I. carved on it. Scarce a fathom above the wooden crofs was a brazen one, at the bottom of which we could fee 1748 , the $15^{\text {th }}$ of No: vember; and higher up a French Infcription, which could not be read, it being too high. On the pole and the wooden crofs feveral dates of years, and feveral names, were carved.

Tife country hereabouts looks like the rocks about our mines. The bircis refted here and there without being frightened, after they had filled themfelves with filhes in the fea. In fome places they had ftained with their dung the heaps of ftones quite white, which then looked like ruined towns, of which nothing but fome white-wafhed chinneys remained.

THE affitant Thollander, a friend and promoter of fcience, parted from me a little while, and found in the mean time the farce Arifida Adfcenfionis. It is faid there is a fpring, or rather a cave, where the rain water gathers, on the fame mountain: but it was dried up at this time. 
84 OSBECK'S VOYAGE.

THE goats, which the French brought upore this illand, were by this means forced to live without water; for, befides fea-water, none is to be met with. But they eat the juicy wild Purflane (Portulaca oleracea), which grew in feveral places between the ftones, was very young at this time, and had but two or three leaves.

$\mathrm{T}_{\mathrm{HE}}$ French had buried fome of their dead this year in one part of the ifland, and in remembrance of them had put upon the graves croffes and white banners.

The following are the natural curiofities which I found on the ifland, befides the abovementioned ftones:

Rats abound here, being brought by Dampier's thip, which was forced to put in at the illand after it had fprung a leak, and to ftay here till another fhip came and took the crew away. Sailors that have been here before relate, that though they hung up their bags of meat on upright poles, they were by no means fafe from thefe vermin; nay, that when the people fat down to meals, they came 
ASCENSION ISLAND. 1752. 85

out as if they demanded a thare of the victuals with them.

THE goats have increafed pretty well. I faw a flock or two which were very thy, yet they might be caught by any one on foot, for they do not run very faft. One of them was taken and brought to our hip. It was of the leaft fort, and very lean. We obferved immediately that it was not ufed to water ; for tho' it drank fome, it immediately ran through it, as if the water had been poured through an inclined tube. It was killed, but its flefh was liked but by few.

SEA birds are numerous here, and, what is remarkable, they were fo bold, that they would let any one come up and take them with his hands.

ThE birds which appeared at this time were :

Tropick birds (Pbaëton atbereus) Grew's Muf: p. 74. Avis Tropicorum. Willougbby. This bird is of the fize of a duck : the feathers on the under fide of the neck, breaft, and belly, and below the tail, together with fome of the moft outward coverts of the wings, are quite

$$
\text { G } 3 \text { white: }
$$




\section{OSBECK'S VOYAGE.}

white: the feathers which cover the head, the upper part of the neck, the wings, and the whole back, are all marked with black tranfverfal ftripes of the breadth of a pack-thread. But the vent-featlicrs are fomewhat blacker: the feven quill-feathers have black edges at the extremities, and are white towards the infide; but the fecondary ones are black in the middle, with white tops: the coverts below the wings are quite white: the wings are fhort: the bill is above two inches long, tharp, very narrow, fomewhat inflected on the fides, and entirely red: the jaws are almoft equal, though the upper feems to be rather fhorter: the margins are ferrated towards the infide, for the advantage of holding their prey : the noftrils, which are almoft in the middle, between the point of the bill and the eyes, are narrow, and end in a little furrow towards the point of the bill; the feathers hang down about the eyes : a black fripe runs down to the head from the eyes: the fect are half naked and footy: the back-tocs are very fmall: two of the tail-fca. thers are longer than the whole bird; and, like all the other tail-feathers, white, with black fhafts. We faw thefe birds in fereral places within the Tropics at an exceflive height; often fàr from land; and generally hovering 


\section{ASCENSION ISLAND. 1752.87}

over the fame place: from whence fome fail. ors have concluded that they continually remained in the air at that height.

The Pelican (Pelecanus Onocratalus'), with the red bag under its neck, flew up and down, but would never fettle. It is the fame which in hieroglyphical defcriptions is ufed as the emblem of great tendernefs towards its young. It lives generally in the great African fandy defarts, where no water is to be met with; but it brings it for many miles in the bag below its throat, and fills the neft of its young ones; whither camels and other animals likewife refort to affuage their thirft. People who have feen it emptying its red water bag, have thought that it ripped up its breaft and gave its young ones blood for want of water; but they were miftaken.

Pelecanus Aquilus: its bill is more than a hand's breadth long, and is narrow: the upper-jarw is fomewhat the longeft, with a hookthaped point: the cere, which is blue, covers the bill from the eyes to the hook-fhaped point: the mandibles have no fuch ferrated incifions (fupplying the place of teeth) as are ufually found in fea birds: the bead is covered

c Orientalis.

G 4

with 


\section{OSBECK'S VOYAGE.}

with hort feathers as far as the eyes, which are pretty large: the tongue is large, almoft trifid at the top; the çorner at its bottom is fplit: the temples are naked; the wings confift of three parts, and are very long; of the twenty-two quill-featbers, the firft ten are of a confiderable length; the two inner joints contain, befides the coverts, twenty-two fecondary feathers: the outward of the twelve tail-feathers are much longer than the middle ones, which make the iail look like a pair of fciffars, The bird is about the fize of a goofe, and is a yard long: the colour of the whole body, and of the toes, is black: but the bead, breaf, belly, and fore part of the neck, are of a fine white. Its food is firhes, which it takes from others, becaufe it is not formed to satch then itfelf: the Englifh, for this reafon, call it Man of War (2. an Fregata Barere?) d

ON our arrival at the ifle of $A f c e n f i o n$ thefe birds met us, and generally kept hovering about the ftreamers as if aftonifhed at them. They fly flowly like kites (Falco Milvus).

- The Fregata of Barrere is, with Dr. Limnaus, Profellias vig Fregata. F. 
ASCENSION ISLAND. 1752. 89

Diomedea Adfcenfionis was caught here. It was entirely white, not even the thirteen feathers in the tail excepted; had red feet, formed chiefly for fwimming; and only black tips to its wings: for the reft, it is -like the Diomedea pifcatoria (Pelecamus Pifcator), which is likewife to be met with here. We alfo faw a fpecies of little black fea birds, but only upon the wing.

Tortoises (Teftudo Mydas) e. They are afh-coloured at top, and pale yellow below: the fore-fect are longer than the hind-feet; the firft are two feet, and the latter about fix inches, long: the neck is two feet in circumference: on the middle of the back, longitudinally, are five fcales, and next to thefe, on each fide, four pair of fcales, of which the two next are oblong, and very large; but the other two pair are unequal: all about the fides are twenty-five fcales: the breaft is longitudinally covered with thirteen fcales, which have four pair of larger ones on each fide : befides thefe, there are feven or more pair of lefs ones about the jaws, one at the tail, and

- Tefudo atra. Muf. Regis. p. 50. Amcen. Acad. I. P. 84. Vulg. Turtles.

likewife 
likewife fome fcales on the fides: the eyes are large, and on one of their fides the raw fleth appeared; the fkin of the eyes is as it were covered with feveral red points or fcales: on the fore-foot, quite at the paw, is a round fcale like a coin : the field which covers the back is frequently above four feet long, and of a proportionable breadth. Thefe tortoifes weigh from 500 to 700 pounds of Swedif grocery weight. Their flefl being boiled fwells exceedingly, and for this reafon a tortoife from Afcenfion Ifland is reckoned equal to an ox, and fufficient to make a meal for 130 men. The catching of tortoifes is a great faving to the company, as they can keep them alive without food for five or fix weeks together ${ }^{f}$, if they are only watered with feawater four or five times every day, fometimes laid on the back, and fometimes on the belly (in which latter cafe fomething is put under their neck), and if guarded from rain and heat. When they are to be killed, the head is firf fevered from the body, and the fhell is next cut off. The flefh is grey, and the blacker it is, the fatter it is reckoned. When

f In 1755 a great tortoife was brought alive to Gotien burgh, but was killed there foon after its arrival. 


\section{ASCENSION ISLAND. 1752。9I}

the fat is boiled, it grows green, and taftes like marrow; the reft of the flefh is moftly white, and taftes like beef. The flefh is boiled in a broth prepared with tortoife eggs, and is eaten with vinegar. It is an excellent remedy againft fcurvy, coftivenefs, and other difeafes. The breaft is roafted, with fhell and flefh, by the name of callopée, and eats exceedingly well, efpecially while the animal is yet fat; but after it has been without food for fome weeks, it is no wonder that the flefh fhould become lean and unpalatable. The bowels and liver are likewife eaten. A tortoife has frequently 500, or 600 , and as I have been told, fonetimes 1500 eggs: they are quite round, have no white, and are furrounded with a foft fkin: they are never eaten by themfelves, but either in foups or pancakes; but the finy tafte prevails, however they are dreffed.

SQualus Adfcenfionis, is a fifh whofe body is bluein at top, and white below: the bead is very flat: the eyes are on the fides, and not at the top: the anal-fin is near the tail: its length is above two feet: the membrana brancbioftega are below the fpiracles, and have fix rays, 
Balistes vetula, which is called the Old Wife fifh by the mariners: the firft dorfal-fin has three, the fecond thirty, the pectoral-fin fourteen, the ventral-fin twelve, the anal-fin twenty-eight, and the tail twelve, rays. In fize and figure it is like the Cyprinus Ballerus. It is of afh colour, approaching towards yellow: the fiin is rough, thick, and covered with rhomboidal fcales. When the filh is caught, it mutters, whence it has got the name of Old Wife. The firft dorfal-fin is triangular, with excavated femi-circles: it has three rays, of which the firft is the ftrongeft, and has a tharp edge on the foremoft fide, with a great many very fhort teeth; this fin can be folded into the furrow on the back of the fifh, fo that it will fcarce be vifible: the fecond dorfal-fin is not armed, but crenated on the upper margin; it has the figure of a parallelogram, is oppofite the anus, and has thirty rays, which (except the fecond, which is very long) are all equal in length: the pectoral-fins are oval, oppofite the firft dorfal-fin, and have fourteen rays: the ventral-fin is fingle, on the middle of the belly, and reaches to the anus ; the firft ray of it is ftrong, tharp edged on the out fide: the twelve lower rays 
have twelve teeth in three rows at the bottom, which accordingly make thirty-fix: the analfin reaches from the anus almoft to the tail, is like the fecond dorfal-fin, and has twentyeight rays : the tail is falcated, and lras twelve rays, of which the outermoft are the longeft: the length of the whole fin is fcarce a foot: the teeth are broad, and eight in each jaw: the lips are thick, moveable, and marked with a blue line on the infide: on each fide run two blue lines, and above thefe a green one, from the mouth to the pectoral-fins: from each eye arife nine crooked green rays on each fide: the eyes are in the upper part of the head, near the firft dorfal-fin; towards the pectoralfins they are large, have a green circle, and are matked with fix oblong blue points at the top: the anal-fin and laft dorfal-fin are blue, and this colour is likewife at the bottom and margin of the tail : the fides are fhaded green below the fecond dorfal-fin: the belly is white, oblong, thick. The fifh eats oyfters and fnails, and is generally caught at the bottom of the fea.

Balistes ringens Linn. Nigra Ofbeck. This filh may frequently be caught with the hands, namely, when the water throws its waves a great way on the land, and 


\section{OSBECK'S VOYAGE.}

you throw fome bread to the finh; for here both birds and fifhes are as it were tame. The firft dorfal-fin has two, and the fecond thirty-four rays: the pectoral-fins have fixteen rays: inftead of the ventral-fins, there is only one fingle ray : the anal-fin has thirtyone rays : the tail is falcated, and has thirteen rays; eight lines run towards the tail: the fcales are rough and rhomboidal: the tect/s are like mens teeth, but double: the anal-fin and fecond dorfal-fin have a blue ftripe at the bottom: the reft of the body is black. The fin is like the preceding (Baliftes Vetula), but generally larger.

Sea Bleculing, Scomber (glaucus s) eminentiis lateralibus cauda aculeatis. The firft dorfal-fin has feven, the fecond twenty-five, the pectoralfins twenty, the ventral five, and the anal-fin twenty-five, rays : the feven rays of the firft dorfal-fin are fome tvhat prickly: the firft feven rays of the fecond dorfal-fin are the longeit, and begin before the anus: all the other rays are fhorter, round, and do not prickle: the fpace between both is very fimall : the pectoralfins are bent, and have twenty rays, of which the moft outward ones are four inches long: the contral-fins are but half thelength of the

\& Adfcenficnis. Ofbecks 
- $A S C E N S I O N$ ISLAND. 1752. 95

pectoral-fins, and have five rays: the anal-fin is higher forwards: the body is narrow, grey at the top, white below, above a foot long, and covered with a fkin: the prominences on the fides of the tail confint of many clofe fpines, $(27,49)$ which form the hind part of the lateral line: its fore-part is bent and unarmed: the head is obtufe: the moutb oblong: the teeth fmall : the lower jarw is the longelt : the opercula branchioftega have no incifions.

Perca Adfcenfionis: the membrana brancbioftega has eight, the dorfal-fin twenty-feven, the pectoral-fins fixteen, the ventral-fin eight, the anal-fin fourteen, and the furcated tail twenty-fix, rays: the dorfal-fin is towards the middle of the fifh: its firft eleven rays are pungent, the fixteen following (of which the two firft are the higheft) are not armed: the opercula branchioftega confift of two plates, which are dentated; two of thefe teeth are large, the others fmall and numerous: the javes are dentated above the noftrils: the firit ray of the dorfal-fin is the thorteft; the fecond is the ntrongett, fharp pointed, and ftridted backwards; the third is fomewhat fhorter and thinner; the reft are not armed: the body is narrow, reddifh at the top, and whitin below: 


\section{OSBECK'S VOYAGE.}

the fcales lie tranfverfally, are oblong, and dentated before.

Trachinus Adfcenfionis. This filh taftes exceedingly well, and is diftinguifhed from others by the following marks: the dorfal-fin has twenty-eight rays, the pectoral-fins eighteen, the ventral-fins five, the anal-fin eleven, the tail fixteen, and the membrana brancbioftega fix rays; the latter is white with brown fpots: the fingle dorfal-fin is every where of equal breadth, and runs from the head to the tail: its firft eleven rays are fharp pointed: the pectoral-fins are obovated; and fo are the verttral-fins; and their firf ray is prickly: the three firft rays of the anal-fin, which is likewife obovated, are prickly : the tail is wedgefhaped, with thort rays : the body is fomewhat compreffed, and not quite round, covered with a white fkin, on which the brown fpots run into one another: the bead is fomewhat compreffed: the opercula brancbioftega confift of three fcales, of which the middlemort ends in rwo teeth; one of them is long and pointed: the eyes are near each other, in the upper part of the head, and are large: the nofrils are round; befides them are two greater holes in the forehead: the tecth are fixed in the 


\section{ASCENSION ISLAND. 1752. 97}

gums and throat in fereral rows; they are numerous, long, and very fharp; five of them are longer, namely, three in the upper-jaw, and two in the lower: the jaws are equal in length.

\section{Of infects I found:}

Dermeftes elytris birfutis cinereis, in the fand.

Hippobofca nigra, on the Pelecanus Aquilo. Mufca vulgatifima.

Mufca nivea.

Cancer Adfcenfionis. A fort of crabs with white points on the feet. They run on the fea-thore between the ftones, and are difficult to be caught; for as foon as they are purfued, they jump very nimbly between the ftones.

Afterias. Of this $\mathrm{Mr}$. Torcen faid he had found one petrified on the fhore. Several Thells lay on the thore, but were generally broken by the waves.

VERY fmall oyfters (Ofrea Adfcenfionis) lay on the rocks on the fhore.
You. II,
H
Of 
98 O B B K K'S VOYA GE.

Of plants I found only the following :

Ariftida Adfcenfionis, on a mountain.

Sherardia fruticofa, a fingle plant on a plain.

Convolvulus pes capre, on the fhore.

Eupborbia origanoides, between the ftones, the food of the goats.

Portulaca oleracea, among the ftones; tho' as yet very tender. This plant was the moft common. Such a poor Flora is feldom to be met with on fo great an ifland. Where the foil was not covered with ftones, it looked like a diftrikt where a foreft had been burnt down. And fome of the aforementioned plants grew here and there. However, on the ftones grows yet

Licben foliaceus albus, and farinaceus, namely, green and yellow, but I was not able to carry any ftones on account of the great heat : Yet I took a couple of pieces of perfect petrified wood with me. One of thefe petrefactions was half a branch of a tree, in which the bark, wood, and grain, were all diftinguifhable. The other was a branch which was fo 
ASCENSION ISLAND. I752. 99

fimilar tö wood, that without a knife it was impoffible to diftinguin whether it was fone or wood. After we had been quite fpent with the unfpeakable heat, fuch as I had never experienced before, we reached, with fome diffculty, the place where we had landed, and regaled our parched bodies. Afterwards, I found on the mountains along the fhore:

Fucus lendigerus, Fucus mifcoides, which the water fomeUlva lactuca, times wafhed up.

At laft.we went about the Crofs-bay, over feveral mountains, to a little creck, where our 1loop waited for us. As I was juft going upon this dangerous road, over a heap of ftones which by little and little had rolled down the hill, a huge ftone rolled down, and was within an hair's breadth of making an end of me; but I happily efcaped, although in the greateft confternation. In this bay boats can land very fecurely, and lie very quietly; for it is furrounded with rocks on both fides, which hinders the water from beating againft the fhore with fuch violence. Though here is but little fand, yet a Mip is faid to have caught eighteen cortoifes in one 
100 OSBECK'S VOYAGE.

night. We caught moft of ours in the Crossbay, becaufe it was nearer to our fhip than the Englifs bay: though in the latter more tortoifes come on thore than in the former; but it would be too difficult, if not impoffible, to bring them over by land from one bay to another; and for this reafon the boats ought to land where the tortoifes are to be had.

\section{The 8th of April.}

CLEAR weather. Little wind.

After we had got all our men on board again, and $4 \mathrm{I}$ tortoifes on the deck, we weighed anchor. With the cable we pulled up a piece of coral, on which a red thell (Pecten Adfcenfionis) was growing, which on its valves reprefented many branches. We took it with us, and at prefent it is preferved in one of the greateft cabinets of natural curiofities in Sweden. In the forenoon we fet fail towards Fayal, in company with the Gotbic Lion. 


\section{ASCENSION ISLAND. 1752. IOI}

\section{The 15th of April, $1^{\circ} \cdot 34^{\prime}$. S. L.}

AFTER a calm for three days together, we got a little wind.

We met a Dutch fhip, which had failed two months from Capon, an African province exactly under the æquator. Her cargo con. fifted of gold-duft and ivory from the Guinea coaft ; but the was in great diftrefs. The captain and the greateft part of the crew were fick, fo that this fhip, notwithftanding her rich lading, was in a very deplorable condition. We affifted her with fome victuals from our thip gratis.

WE caught two bonets.

\section{The 16 th of April, I5'. S. I.}

Clear weather. Little wind; but exceffive heat.

In the bonets which we caught to-day were little worms furrounded with wrinkles or circles, having a probofcis on the fide of the opening at the head, and a globofe tail. 
102 OSBECK'S VOYAGE.

VTE likewife caught a fpecies of rmall firhes, which in fize were equal to fticklebacks. It was

Gobius tropicus. The membrana brancbioflega has three or four rays: the dorfal-fin, from the head almoft to the tail, has twelve and more rays: the pecioral fins have fifteen, the ventral-fins have eight, and the anal-fin has twelve, rays: the tail is round: the body likewife, and thin towards the tail: the fcales are tharp: the bead is great, wrinkly: the opercula brancibioftega confift of two long, linear, dentated orbiculi: the mouth is great, almoft round, and covered with the $\mathrm{kin}$ of the head: the eyes are large, and ftand on the fides.

WE again faw a grampus, which fpouted up the water with great force.

The 2 oth of April, $3^{\circ} \cdot 4^{\prime} \cdot$ N. L.

THE fea was entirely calm. We caught bonets and tunnies both to-day and yefterday, and the day before. 


\section{ASCENSION ISLAND. 1752. 103}

\section{The $22 \mathrm{~d}$ of April, $3^{\circ} \cdot 23^{\prime}$. N. L.}

LitTLE wind. Thick air.

IN the tunnies (Scomber Thynnus), we found two forts of filhes, befides the Sepia Loligo, or cuttle-fifh. The one was very like a Crufian. It was

Clupea Tropica. The menbrana branchiofega has feven rays: the fingle dorfal-fin runs from the middle of the back to the tail, and has twenty-fix rays: the pectoral-fins have feventeen rays: the ventral-fins fix, and the anal$f i n$, which is the length of the dorfal, twentyfix rays : the body is tharp, deep, with white fcales : the lateral-line is ftrait, and runs away near the back: the belly is ferrated : the bead is obtufe: the lower-jaw is longer than the upper: the moutb oblong, great: the teeth are in one row in the jaws; they are numerous, fmall, and fharp: the eyes are near the mouth: the opercula brancbioftega confift of two orbiculi, which are both covered with fcales: the tail forms a wedge, and has twenty rays. This is a new fpecies. 
104 OSBECK'S VOYAGE.

THE other fpecies of firh was reckoned a Flying-fish, but its pectoral-fins were very fhort.

$$
\text { The }{ }_{3} \mathrm{~d} \text { of April, } 3^{\circ} \cdot 25^{\prime} \text {. N. L. }
$$

Is the forenoon heavy rain.

'The $24^{\text {th }}$ of April, $3^{\circ} \cdot 3^{6}$. N. L.

RaIny weather, and good wind.

Some tunnies were caught.

$$
\text { The } 25^{\text {th }} \text { of April, } 5^{\circ} \text {. N. L. }
$$

DARK fky. About noon heavy rain.

A Dog-fish was caught as ufual with a hook baited with an Old Wife firh (Baliftes Vetula.)

THE two next days were calm, and we likeswile caught dog-fifhes. 
From Afcenfion Ifland to the Gra/s-Sea. 1752.105

\section{The 28 th of April, 60. 2'. N. L.}

THE N. E. wind now began to blow, and in the fpace of a fortnight helped us over the tropic of Cancer.

THIs wind is conftant here all the year long, though it varies fometimes to one and fometimes to the other fide. The fhips, both on their going and return, are obliged to avail themfelves of the fame trade wind. They are therefore obliged to get on againft the wind, and lail with a confiderable bend till they at laft gain the right courfe with weftern winds, and are enabled to get out of this calm fea.

Bonets and tunnies were caught, and in their bellies we found Cuttle-fig and little crabs.

WE faw a fhip to the leeward, which we thought was an Eaft Indiaman on her voyage to India.

IN the next twenty-four hours we caught fixty-eight tunnies and bonets.

\section{The}


106 OSBECK'S VOYAGE.

The ift of May, $8^{\circ} \cdot 57^{\prime}$. N. L.

Clear weather. Frefh trade wind.

FLYING-FISH (Exocatus volitans), which were three or four inches long, and fomewhat different from the Exocatus of Artedi, were caught here. The membrana branchioftega has eight, the dorfal-fin four, the pectoral-fins twelve or fifteen, the ventral-fins, which are in the middle between the pectoral and the anal-fins, have fix, the anal-fin nine, and the tail nineteen, rays; thofe of the tail are very fmall.

Some tunnies were caught, whore bellies were quite empty.

The $2 \mathrm{~d}$ of May, $10^{\circ} .6^{\prime}$. N. L.

Clear weather. Frefh trade wind.

Bonets, tunnies, and flying-fifhes were feen in great numbers. In a tunny we found a narrow, white finh, feven inches and a half long, which the failors call the Chineje Garter. 
It is Syngnatbus argenteus. The membrana brancbioftega has one ray: the dorfal-fin, which extends from the head to the tail, has forty-fix rays: the pectoral-fins are near the head, and have fourteen rays: the ventral-fin confifts of a fingle very finall oflicle or ray, which ftands under the belly very near the breaft: the anal-fin is an inch and a half before the end of the tail, and has twelve rays: the tail is entire, and has twenty-four rays: the bead is pointed, and is fomewhat above an inch long: the lower-jaw is the longeft: the teeth are fharp-pointed, ftand in one row; thirty-one of the largeft ftand before in the upper-jaw: the eyes are great: the body is narrow, of the thicknefs of a finger: the fcales are fmall.

Some of our failors faid, that when they were at Aynom in the thip called The 2ucen, they had eaten a fpecies of dried fines which were very like this; that if they were eaten frefh they would do no hurt, but would be more unwholefome if dried.

As eclipfe of the fun, which could not be obferved in our country, was very confiderable here. The clouds hid the fun from us before 


\section{O SBECK'S VOYA GE.}

the beginning of the eclipfe, which hindered our obfervations till three quarters paft five o'clock, when the moon covered two thirds of the fun, after which the flisy prefently became cloudy.

\section{The 9th of May, $19^{\circ} \cdot 20^{\prime}$. N. L.}

IN the night we were paft the fun (for fo the failors call the fun's paffing through the Zenith) for which reafon we could make no obfervations to-day, though it was fair. In the afternoon the wind grew changeable and calm. Tunnies, bonets, and fying-fifhes were ftill caught as in the laft week. The fea-weed which fwam by us, and had been obferved yefterday, was a fore-runner of the fo much wilhed for Grafs-fea.

Some of our people fuffered a great deal from head-aches : fome of them thought that the complaint arofe from the fmoaked tunnies and bonets; and remembered that when they were on board The Queen, where they had the fame food, they fuffered by the fame diforder.

We now again obferved a Tropick-bird. 
THE GRASS-SEA. 1752. I09

The Ioth of May, $22^{\circ}$. N. L.

GLEAR weather. Weak trade wind.

The Grafs-fea is that part of the ocean in which the Eaft India failors meet with feaweed (Fucus natans) fwimming in greater or lefs quantities; though all forts of Fucus are called fea-weeds. We entered the Grafs-fea in our return on the $7_{\text {th }}$ of May, in feventeen degrees and a half north latitude, and twentytwo degrees and a half of weft longitude, from Afcenfion Ifland, and $37^{\circ} \cdot 21^{\prime}$. weft longitude from London. The weed in the firft days came but ever now and then, in fmall quantities; but in $26^{\circ}$. latitude in great heaps, fometimes feveral fathoms long. This appearance continued to the $25^{\text {th }}$ of this month; when a frefh foutherly wind at twenty-four degrees and a half latitude, twenty-four degrees and a half wert from Afcenfion Iland, and $39^{\circ} \cdot 9^{\prime}$. weit from London, brought us out of the Grafs-fea, on which we had fufficient time to make obfervations, by the calms and very gentle winds which then prevailed. 
IT feemed at finft as if this wandering fea plant (Fucus natans), which met us with a northern wind, came from the African coaft, or the ifles on that fide. But in that cafe, it is plain we fhould have met it on our going out; becaufe in this very latitude we failed much nearer to that continent, but yet never faw any fuch fea-weed there. The northern trade wind, which purhed us onward from the fixth degree of latitude on this fide the aquator, makes the Eaft Indiamen on their return take their courfe more to the weft than would elfe be neceffary; and then they meet with more or lefs fea-weed in proportion as they approach more or lefs to the American continent. From whence we may conclude, that this plant comes from America, fince it likewife appears from the accounts we have, that it is to be met with in great quantities in the Gulf of Florida, whence a great ftorm drives it into the open fea; and the wefterly winds carry it fo far, that even thofe who come from the Eaft Indies get a fight of fome of the produce of the Weft Indies : but other winds keep it from coming quite to Africa, and keep it floating about the ocean. From this, bonets, tunnies, and other filles get their fubfiftence; 


\section{THE GRASS-SEA. 1752 .}

they fearch this weed well, and take what they like out of it : not to mention that one fort of little fithes or infects which inhabit this feaweed, ferves as food to others.

THE ftalk of this ramofe plant, which however is farce diftinguifhable in thicknefs from the branches, was not above a foot long, and without all appearances of roots; yet it was able to pufh out new leaves for further encreafe: the globofe parts of fructification were (like fome of the leaves, ftalks, and branches) harder than ufual; occafioned, as it feemed, by the flime which fometimes faftens itfelf on the leaves, branches, or other parts: in this fome very fmall blackifh grains, or rather eggs of crabs, and infects, are inclofed: when thefe infects afterwards forfake their habitations, they leave marks in the hardened flime behind them. Sometimes a flime exceedingly like the whites of eggs fticks to the leaves, in which an innumerable quantity of fnail's eggs joined together make a white or yellow chain, like a Tonia, fo wound backwards and forwards that one can neither find its beginning or its end. I could neither in thefe nor in the preceding ones, obferve any fort of thape or life, with the microfcope. After they had 
been put into water, for fome hours every pare was put into diforder and diffolved. If this and the preceding matter is not Dampier's fifhroe, which is faid to fwim in the Sargazo, I have not met with it. In ftormy weather the Sargazo does not fink, but keeps on the furface of the water, except when the force of the waves or the courfe of the water (when it approaches the fhip) fupprefs it; in this cafe it finks lower, and gives a green light, though its colour is yellow. If it is again thrown into the water, it makes the latter to foam violently. In wet weather it exfudes a faltifh fubftance, tho' it was well dried before. If it is prepared with vinegar, it is reckoned as good as famphire (Critbmum), which in Spain and England relifhes fo well with roafted meat. Why may not fome of our fpecies of feaweed ferve the fame purpofe? In this cafe we fhould have a fufficient quantity both for inland ufe and for exportation. In this migratory fea-weed were the following animals:

$\mathrm{T}$ н Е American frog-fi乃h, Lophius Hifrio Linn. Syft. Nat. or Lophius tumidus Muf. Reg. p. 56, and Dr. Linnæus's Weftgotbic Fourney, tab. iii. fig. 3. Its cirrus and firft dorfal-fin are briftly at the top, and thofe briftles are foft. 


\section{THE GRASS-SEA. I752. IIริ}

The whole body is covered with a flimy fkin, and little foliaceous fulcra, which are fcarce obfervable while the fifh is in the water, becaufe they fit fo clofe to the body. The mouth and belly are large, in order to receive many fpecies of crabs or young thell-filh. Perhaps Providence has clothed this filh with fulcra refembling leaves, that the fifhes of prey might miftake it for fea-weed, and not entirely defroy the breed.

Cyprinus pelagicus. The dorfal-fin reaches from the head to the tail, is lower in the middle, and has thirty-fix rays: the pectoral-fins have fifteen, the ventral-fins fix, the anal-fin twenty-eight, and the furcated tail twenty-two rays : the irides of the eyes are yellow like gold: the moutb is oblong: the body is very narrow, whitilh, and every where covered with very fmall fcales.

Syngnatbus pelagicus, corpore medio beptagono pinnâ dorfi anum verfus. The dorfal-fin has thirty-one, the pectoral-fins have fourteen, rays: the ventral and anal-fins are wanting: the flabelliform tail has ten rays: the whole length of the filh is about a fpan: it is as thick as a goofe-quill. From the head to the VOL. II. 


\section{4 OSECK'S VOYAGE.}

anus, or nearly to the middle, it is heptagonal, and has eighteen rings; but lower down it is quadrangular to the tail, and has thirty-two rings. The female (according to Artedi's Syn. iii. p. 3.) has the ovary near the anus, where he likewife fays, that the body is polygonal, and broader below: the bcak is long, cylindrical, and narrow.

Scyllaa pelagica, or the Sea-bare. Seba took them for the young ones of the Lopbius tumidus, Muf. Reg.: but it is difficult to perfuade one's felf of the truth of this; unlefs fomebody would kee? them, and obferve their changes. The following is their defcription: the body is like a jelly, oblong, narrow, of a yellow-grey colour, and has a longitudinal fiffure below, by means of which it can furround the fea-weed (Fucus) both lengthways and crofs-ways with the fore-part or hind-part: it is two inches long, and fcarce one inch broad: the fides are flat, with little carnofe, cone-fhaped, whitifh prominences: the back (which by fome has been miftaken for the lower-part) is almont flat, with very fhort, dark briftles, and tharp-pointed margins, to which fome appendages (Fulcra) or erms and fins are faftened: the bead is compreffed, 
preffed, fomewhat pointed, and difficult to be diftinguifhed when dead: the antenne are fhorter than the head: the moutb has no teeth, and has a pilofe margin below the beak: the throat is fmall, almoft round: the tentacula are upwards, not far from the top of the beak; they are oblong, foliaceous, fhorter than the fins, fomewhat broader before, with a deflected hairy margin, and a carnofe cone in the middle; they likewife ferve to grafp the fea-weed. The animal has on each fide two fins at equal diftances; they are foliaceous, oblong, fomewhat broader before, curled, with briftly or lacerated edges, and are placed on the rough margin of the back: the belly is in the middle of the body, narrow, oblong. The parts of fructification of the fea-weed, which it eats, were vifible in it. The tail is perpendicular, foliaceous, almoft round, broader, but fhorter than the appendages, and ciliated. This animal moves very flowly in the water ${ }^{a}$, by bending its extremities.

Cancer peldigicus, bracbiperus, manuum articulis omnibus dentatis, extimo beptagono. The pinchers of the cbely bend out very little, are

2 I hould perhaps have called the tentacula, bands, and the fins, four feet.

$$
\text { I } 2 \text { ftreaked, }
$$




\section{OSBECK'S VOYAGE.}

ftreaked, dentated, and of equal length: the the other feet have but one toe: the fides of the thorax are ferrated, the hind-part is long, ftrong, tharp-pointed: the colour is a brownilh yellow, with whitifh unequal fpots: the tail of the female is much broader, round (with a fhort point), and confifts of feven articulations : the tail of the male is almoft triangular, and has four articulations: on each fide of the tail is a fingle, long, bent briftle, which is thicker below, and bears a great refemblance to the lateral rays of a fin.

Gancer minutus is the moft numerous of all infects here, and feeds upon fepias and little crabs. It 1kipped about on the furface of the water with exceeding great agility, from one heap of fea-weed to another, which is fometimes feveral fathoms diftant, and when it caught a worm, it tore it with its chely, and crammed it into its mouth bit by bit.

The rath of May, $24^{\circ} \cdot 15^{\prime}$. N. L.

YESTERDAY and to-day we had generally a calm. 
THE dolpbin, or Coryphana bippurus, had the following characters: the membrana brancbioftega has feven rays: the body is greenifh dotted with blue, two feet long, narrow, fharp-pointed: the bead is obtufe, fhort: the lower-jaw is the longeft : the eyes are globofe: the irides are gold-coloured: the teeth, which are fhort and numerous, ftand in the jaws and gums: the back and bclly are fharp: the tail is furcated: the fingle dorfal-fin begins on the middle of the head, and goes to the tail; towards the head it is the broadeft; it has fixty rays: the pectoral-fins have nimeteen, the ventral.fins fix, and the anal-fin, which extends from the anus, or from the middle of the fin to the tail, has twenty-fix rays: the tail is bifid, and each of its parts has twenty rays. The fifh is exceedingly quick in its motions, and in the water feems fhaded with black and green: the ovary is oblong, double, and large: the lateral-line is bent, runs directly by the back, and is fcarce diftinguifhable between the head and the anus. This fin is very feldom met with, except in fuch places where the winds are changeable, that is, only within the Tropics.

$$
\text { I } 3 \text { Bonets }
$$


BoNETS and tunnies were more fcarce at prefent; but appeared in thoals the next day towards evening. To-day, as well as the following days, the afore-mentioned natural curiofities were caught in the Grafs-fea, and put into fpirits, to be brought home.

The 2oth of May, $28^{\circ} \cdot 34^{\prime}$. N. L.

Among other fifh we met with the Dorada, which is about a yard long, and very like the dolphin, for which reafon Artedi makes it the fame fpecies of Coryphana. But that which we caught at this time was different in the following particulars:

Coryphena Equifelis. The dorfal-fin, which extends from the middle of the head to the tail, has fifty-three, the pectoral-fins have nineteen, the ventral-fins have fix, the analfin has twenty-three, the membrana brancbioftega fix, and the tail has twenty, rays. 'This Dorado is in general much more fcarce than all she reft, fo that many people have often been in the Eaft Indies, without ever having feen it. 


\section{The $22 \mathrm{~d}$ of May, $30^{\circ} \cdot 45^{\prime}$. N. L.}

A vessec which we had feen for fome days together, now came near us. The name of the thip was Duc de Parme; it was commanded by Chevalier d'Arquis, came from Bengal, and was deftined for Port l'Orient in France. The clear weather and moderate wind gave us opportunities of vifiting each other on the open fea. Our firft fupercargo dined aboard the aforefaid hip ; and two gentlemen from the other Swedifh thip which accompanied us, dined with us.

$T_{H E}$ following days there was generally a calm, which likewife permitted the fhips to keep company with each other.

The 26 th of May, $35^{\circ} \cdot 24^{\prime}$. N. L.

BONETS and tunnies were caught for the laft time; though we faw the latter in the following days. Now we took leave of the Grafs-fea. 
The 28 th of $\mathrm{May}, 3^{\circ} \cdot 24^{\circ}$. N. L.

Storm. Cloudy in the forenoon; but generally clear afterwards. In the forenoon we were on the latitude of Fayal, which, as well as the other Azores, belongs to the Portugueze. We then failed acrofs the longitude, till we faw the Pico of Fayal, on the $3^{\text {oth }}$ of May at four o'clock in the afternoon; but the 3 Ift we paffed the Pico of Fayal and St. George, which lie in $38^{\circ} \cdot 3^{8^{\prime}}$. latitude. The fhips had orders to ftop at Fayal, and to make enquiry concerning the ftate of Europe : but on account of the ftrong wind it was thought expedient to fail on. I therefore miffed of a great number of unknown plants, which are undoubtedly to be met with in thefe iflands, lying almoft in the midule between Europe, Africa, and Anesica.

\section{The ift of $J$ une, $41^{\circ} \cdot 10^{\circ}$. N. L.}

Clear weather; and likewife cloucy. Brifk contrary wind. 


\section{From FAYAL to ENGLAND. 1752.
Turdus Chinenfis, Diff.Lbin. Lagerftr. I 121}

is by the Clinese called Whammay (Linnaus in his Nerw Syftema Naturce calls it Turdus canorus), and might, on account of its ftrong voice, be called the Cryins Thrufh. It was fold for a piaftre at Canton, and died here: for which reafon I put down the following remarks: the bill is angulated-conic, the back part of it fomewhat angulofe : the tongue is as it were torn and emarginated before. The wobole body of the female is ferrugineous, except three quill and three tail feathers, which for the greater part are white (this circumftance is feldom to be met with in the other fpecies of this genus): about and near the eyes is a Short white line: the belly is blueifh : behind the noftrils are fome briftles: the bill, legs, and feet, are whitin: it has twelve quill-feathers, and twelve in the tail, which latter are the fame length with the body: in fize it equals our black bird. It eats rice, moths, flies, and flefh. To-day we met an Englifh thip which had failed from London fixteen days ago, and was bound for America, having both male and female flaves on board. 
122 OSBECK'S VOYAGE.

The $3^{\text {th }}$ of fune, $49^{\circ} \cdot 16^{\prime}$ N. L.

Wiтн the lead we found ground at ninety fathoms laft night; it was a fine brownin fand.

\section{The $14^{\text {th }}$ of Fune.}

Clear weather. Moderate wind.

WE at laft faw the Scilly Iflands in the forenoon. Thefe iflands and rocks are very low, and therefore do nor appear before one is quite up with them, for which reafon many thips have been loft juft at the entrance of the Britif Channel, notwithftanding there are two lighi-houfes erected for the ufe of feamen. The rocks difcovered themfelves to us by the breakers. Fucus divaricatus, veficulofus, et Zofera, came fwimming from the fhore. Englif boats came from the Scilly Iflands to us, with butter, lean theep, geefe, ducks, chicken, eggs, plaifes (Plcuronectes Plateffa Linn.), rock-filh (Labrus fuillus Linn.), potatoes in baftets, turneps, cabbages, long and purplered beet, fallads, and (Critbmum maritimum) ramphire; which latter, when cleared of its 
NEAR ENGLAND. I752。 I23 roots, coarfe ftalks, and the adherent Nardus Aricta, fatia armeria, Arenaria rubralet Lichenes fcyphiferi, is put into falt-water for twelve hours together, and afterwards boiled with vinegar, alum, cloves, and ginger (which two fpices are however not neceffary).

IN the afternoon we paffed the Land's End, the firt promontory of England in the Channel, where the tides make up for the lofs of wind. The tide met us at the Lizard, in the evening; a neck of land from which the Englifh generally count the longitude of places; as do likewife Swedift feamen, who generally make ufe of Englifh books.

\section{The isth of June.}

\section{Clear weather. Little wind.}

We failed by Plymouth. The fine fields hereabout, and grounds which are furrounded with quick-fet hedges, afforded a charming view. The chalk hills on the thore made it appear white and high. 


\section{OSBECK'S VOYAGE.}

\section{The I 6th of fune.}

HeAvY rain, and contrary wind all day.

We paffed DevonfBire and Dorfet/Bire, and came in the afternoon to Dover, that wellknown Englifl town and caftle, which is exactly oppofite to Calcis in France, and is not far from it; fo that both kingdoms may be feen at once, if you fail through the Channel. At Dover we went on fhore, and purchafed beef and mutton, cabbages and cauliflowers, cucumbers, carrots, fallads, parfley, fage, leeks, artichoaks, beans, beer, bread, \&x.

TH E people came on-board us, and offered men's cloaths, thoes, wigs, hats, ftockings, watches, and fuch things, for mcney, or E.aft India goocis; preferring green teas to moft other tlings : the brown teas are not reckoned of any great value with them. After we had taken in the neceffary refrefhments, we directed our courfe to Gottcnburgh. On this voyage we met amongt feveral other Ahips an Englifh one bound for Peierjourg/t. 
The $25^{\text {th }}$ of Fune.

After a voyage of eight days, we happily got fight of futlond.

The 26 th of Fune.

WE faw Marftrand and the Gottenburgls Rocks; and yet in the forenoon we caft anchor under the caftle of Elfsborg. After the cuftom-houfe officers had put the feal to our cabbins, I went on hore again with great fatisfaction and in perfect health.

WE loft eight men on the voyage: of thefe one died of a dyfentery, one of the pleurefy, three of agues, and three loft their lives by accidents. But thanks be to GoD, who has fo fuccefsfully brought 124 men back to their own country. 

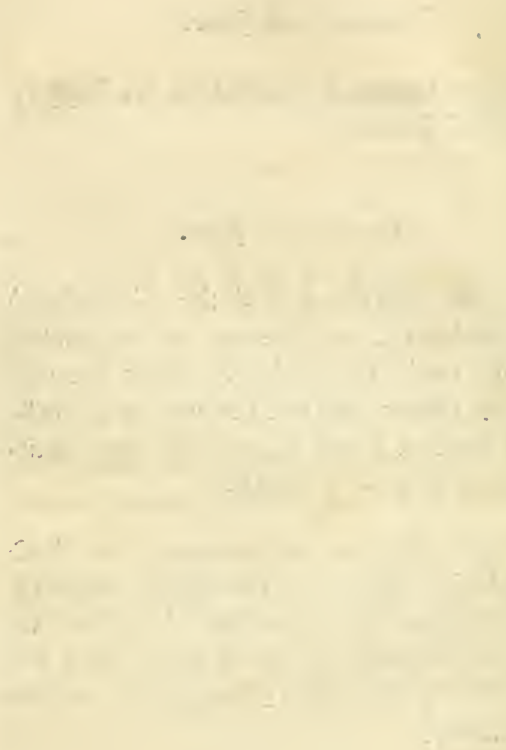

$\therefore$ 


\section{$[127]$}

\section{LINNÆUS'S LETTER.}

T O

$M_{R} . \quad O S B E C K$.

\section{S I R !}

T HAVE read your excellent book with 1 pleafure and furprize. It cannot be difputed, that few books are fo agreeable to the public as accounts of voyages, where fomething new is always found to gratify the reader's curiofity, and enlarge his underftanding. But moft of the royages hitherto publifhed, by impofing barbarous names on their difcoveries, have rather fharpened our defire after knowledge, than afforded any real inftruction. You, Sir, have every where travelled with the light of fcience : you have named every thing fo precifely, that it may be comprehended by the learned world; and have difcovered and fet- 
I28 A Letter of Sir Charles Linneus.

tled both the genera and fpecies. For this reafon, I feem myfelf to have travelled with you, and to have examined every object you faw with my own eyes.

IF voyages were thus written, fcience might truly reap advantage from them. I congratulate you, Sir, for having traced out a way in which the world will follow your fteps hereafter; and, purfuing this career, will remem. ber the man who firft pointed it out.

Charles linné: 


\section{$\left[\begin{array}{ll}\text { I } 29 & \text { ] }\end{array}\right.$}

\section{A \\ S P E E C H,}

SH E W I N G

What thould be attended to in Voy AGES to CHINA,

DELIVERED BY

P E T E R O S B E C K,

On his being chofen a Member of the Royat Swedish Academy of Sciences, at Stockbolm, the 25 th of February, $175^{8}$.

\section{Gentlemen!}

THE greateft rivers often come from the 1 leaft fprings; and fo the leaft caufes may produce the moft confiderable effects. The ableft men in all fciences therefore pay great attention even to the minuteft information, which is defpifed by perfons of inferior abilities: they expect no fruit without a preceding flower, no fcientific knowledge without fimple but fundamental principles, and no experiVox. II. 
ments without previous introductions. To prove this at prefeat is hardly neceffary, when all you, Gentlemen, are living inftances of the wuth of my affertion; you protect even the dlightert flietclies, if the intention be good, and are continually labouring for after-ages. The honour you have conferred on me in particular, in chuing me a member of your leared Socicty, will raife my refpect and reneration, and encourage me to proceed in the fame career.

Giva me leave now, Gentlemen, to begin with malking a fhort difcourfe upon fome Injirudtions how far attention may be ufful to the fulblic in voyages from Sweden to China.

Attention has always its ufe, which in part appears immediately, and in part avails pofterity. Whatever ferves for food, or the amendment of health, is looked upon as ufeful by all without exception; they are two of the moft confiderable advantages; for the calls of Iunger admit of no delay, and ficknefs is the firt ftep to death. But our enquiries may be extended to other objects, which are confidered as neceffary. Each of our fenfes expects its peculiar gratification, and this fometimes from 
from the moft diftant parts of the world. That other nations may not run away with all the advantages arifing from carrying merchandize from place to place, we are obliged to fetch foreign goods ourfelves by long voyages. It is advantageous to trade to take time, and to have a free uninterrupted courfe; and therefore we prefer going by fea : to this the compafs is not only ufeful, but abfolutely requifite; yet it is probable that at firft the effects of the load-ftone were looked upon as trivial, and it is doubtful whether the inventor got a proportionable reward for its difcovery : but time has hewn, that the firf attention to this object has been of great and almoft ineftimable ufe. Our attention muft therefore not merely extend to thofe things of which we already fee the ufe, but likewife to thofe from which we till may expest it.

Follow me therefore, Gentlemen, over the foaming waves to the Spanifh flores, and over a boifterous fea to the riches of the $I n$ dics: but we thall here mention only a fmall part of what will gratify a laudable curiofity, and confine ourfelves to domeftick ceconomy and natural hiftory, which will be amply fuf- 


\section{Of ilit Ufefuliness of Attention}

ficient to give birth to fuch reflections as maj be ufeful to yourfelves and your country.

Such a voyage is undertaken in the coldeft feafon, in the ftormy Norember, the dark $D_{c}$ cember, and the following winter montlis. This regulation is rade on account of fetching money from Spain, and left the monfoons in the Chinese fea fhould be loft. I do not fpeak of thofe voyages which are made firft to Suratt, and: thence to Cbina; for thefe are begun in the fpring, and have only the voyage hoine in common with the other.

THE exchange of a good warm room for a cold thip-cabin (for there is no other fire onboard except that by which the meat is boiled) is a mof fenfible change, when the body is not well fccured againt the rigours of the feafon; and efpecially to thofe who cannot keep. in continual motion." The penetrating cold of the fea can hardly be kept off by any thing elfe than furrs. The moft common cloathing of our failors about this time are fheep-fkins, which are bought of the Danes in the Sound; and are faid to be fo fwell prepared, that they do not tore their foftnefs even if they are wora in the heavieft rains and fnow. I thould 
think they might be prepared in Szeeden too: Ikins cannot be wanting in a country which is not only capable of, but obliged to breed fleep, and without which it cannot fubfirt.

For fear of mifing the true entrance into the Channel, the thips chufe rather to go north about Ireland; for a fecure road, though round about, is always preferable to a dangerous one though more direct.

Our Eaft India hips fhould not wih to fee the Faroe Iflands, were it not to efcape their foggy rocks. Yet there is no country but has its peculiar advantages. It is cold, but it has plenty of furs for cloathing. The theep, whofe delight ate hills and dry paftures, grow very fat here. The want of bread is fupplied by dried filh; a food which, with fome others, might be introduced to great advantage in fuch places of our country where fifheries obtain, efpecially during thefe times, when every thing bears fo high a price. The wife inflitutions of the Creator are glorions in directing nature to fupply us with one thing inftead of anothe: which we want: if fome places have barren mountains and dry hills, they are generally counter-balanced by fine rivers or feas fwarm-

$$
\text { K } 3
$$

ing 
ing with filhes. But we deviate too far from our voyage; the providence of GOD, and the light we derive from that fource, may well enrapture our fenfes, and for a time engrofs all our idcas.

WE left off at the ferenteen Feroe Iflands, but muft hafte from them to the Spanifs Sca, and its majeftic wares. On the way we meet with a fpecies of whales called the Grampus, but are obliged to leave them to the nicer obfervations of thofe who may for the future find better opportunities of enriching the fcience with a perfect natural hiftory of whales. The Gotbenburgh merchant, Mr. Pcter Bagge, who by means of this Royal Academy has offered to bear the expences of a natural hifforian that fhall attend the Swedis whale filhery, deferves honour and thanks for fo generous a defign.

$\mathrm{ON}_{\mathrm{N}}$ our voyage, Spain is the firft continent where we reft: here is a confiderable degree of warmth even in Fansary. The fineft fruits are then gathering from thofe trees which we keep in our hot-houfes, and the fieids are adorned with beautiful flowers. We meet with people who underftand feveral languages 
in the port towns hereabouts, of which Cadiz and Port Mary are the firft we fee.

Cadiz, which in the times of the Phonicians and Romans, and before its deftruction by the Moors, was very fplendid, may afford many objects of enquiry to an antiquary. The bifhop here might be able to produce feveral curiofities out of his own library, and perhaps fome remains of our ancient Goths in Spain. This is what I leave to others. The eating of flefh in Lent is allowed only to fuch invalids as have exprefs leave to do it. I could not during my ftay obferve that fafting was any way conducive to religion; but it might be a momentous circumftance with regard to diet and oconomy. The Spanifs meat is (at leaft about this time) very bad. By this they fee themfelves obliged to procure the more fill, for which they have fufficient opportunities; but more efpecially to cultivate fruits, which are here fold in plenty. Perhaps fuch a periodical faft would put our gardens into a better condition, and prevent many difeafes, which if they do not arife from, yet are encreafed by, the fuperfluous confumption of Iefh.

$$
\text { K } 4 \text { Cabinets }
$$


136 Of the Ufefulne ss of Attcntion

Gabinets of natural curiofities cannot be greatly enriched at Cadiz, if you except finhes; the exact enquiry into which requires fome time and patience. If they are put into Spanifs brandy, which is ftrong enough for the purpofe of preferving, it would be too expenfive to have each fort in a particular bottle; and it would likewife take up too much room; but if a thread is faftened to the firh, and a piece of lead or fomewhat elfe with holes or numbers, hangs on it, you may put many into one glafs, and mark the Spanif names on the lcads. Quadrupeds, birds, amphibious animals, and infects, are not fo frequent here, unlefs a cabinet of natural curiofities could be found at Cadiz by fome future naturalitt. Plants belonging to phyfic may here be examined in the apothecaries thops. Thofe who have bought our common fumitary (Fumarica Sicata), which by our Eaft Indiamen is ufed againft the fcurvy, and who probably profited by it much, can affure you that it is to be got here likewife; but I can afcertain its growth about Port Mary, in cafe it fhould not be found in the apothecaries fhops. It is the fame thing with many of our common remedies. Ningl, the moft raluable root, is brough: 
brought hither from the Weft Indian plantations. Such a frefh root, if it could be found and brought to Sweden, would be very well received in our hot-houfes. As for ftones, you find a great number of varieties of marble near the great church, which they have already been fo long building. The ftones with which the Spaniards build are compofed of thells, and are to be met with every where. If we go out of town, we find the flying loofe fand moft plentifully, which often fpoils the fineft fpots of ground, and feldom leaves any thing but the Spartium monofpermum behind it, which withftands its utmoit fury, and the feeds of which lie in great quantity on the fand, and will keep for a long time. This plant is as yet unknown in our country, and might at leaft be made ufe of to furround beds containing tender plants.

ON going from hence on the high road to the towns of Chiclana, Ifla, Port Real, Xerez, and Port Mary, which an attentive natural hiftorian ought to do, on foot, you are doubtful what to fix your eyes upon. A good company and Spanifh drefs (I mean a white cap, a hat flapped down, and a thin brown great coat over the common cloaths) eafe the incon- 


\section{$\operatorname{li}_{3} 8$ \\ Of the Ufcfulnefs of Attention}

reniencies of the journey. A bound folio with writing paper to put plants into, a box or two with pins to collect infects, a pair of fciflars, and a pocket book to write upon, may be hid under the great-coat. The fciffars muft fupply the place of a knife, which it is forbidden to wear. Books of natural hiftory would be very ufeful on fuch a journey; but, to avoid the fufpicion of their containing any thing againit the religion of the country, one is obliged to leave them on-board the fhip.

AftER Tie have feen thefe towns and what they contain, we at laft ftop in Port Mary, where we have more opportunities than at Cadia of making collections from the neighbouring gardens, meadows, and fields.

Tine plants which are to be met with here about this feafon are mentioned in my voyage; but at other times more may be added. Each recuires a particular attention, but I will only ipeak of one or two. It ought to be tried whetion the Coccus cacti, the infect which gires us the cochineal, is to be met with on the Cacits oustia, which here grows in the ruick-hedges. Our flax, which grows fpontanuoufy here, takes fhelter under a little fhrub 
(under the Palmito): ought not we to follow nature, and to fupport flax as we do peafe, efpecially in the open field, where it is apt to be damaged by the wind, beat down by the rain, and frequently rots while it is yet ftanding in the ground. I have feen that they put fticks among the flax in Wingocker, and have heard that the fame was practifed at Wadfence by the foreigners who live there, and work at the cambrick manufacture.

THE lovers of infeets find feveral very fcarce beetles in the Spanifo flying fand: thefe are Scarabous typhous, Tenebrio muricatus, Meloe majalis; and magnificent butter-flies, fuch as Pajilio rumina, and feveral others.

Tue water requifite for the voyage to Chinc is, for the moft part, fetched from this town by our fhips, and it is certainly exceeding clear; but in time it becomes fo full of worms, that they creep about in it as maggots in cheefe : by boiling, it gets a brownifh colour, and always maintains a bad tafte. In a country where lemons bear fuch a low price, it might be tried, whether the growth of thefe worms could not be ftopped, by mixing the water with lemon juice as foon as the veffel is filled; 
filled; perhaps the little eggs of the worms, which are undoubtedly already in the water, might be killed by it in the beginning, and by this means hindered from becoming fea wood-lice (Onifcus aquaticus), and other infects, which make the water naufeous and unhealthy. Such experiments ought to be tried before credible perfons, and not be pronounced as good before they have been often repeated. If this expedient fucceeds, we are delivered from a great inconvenience; and if it fails, it does not hurt the water, but makes it capable of affuaging thirft much better. We reckon lemon juice very wholefome for internal ufe : sut, according to the account of our Spani/s pafienger, it occafions a pain in the hands if you frequently wafh them in it.

Bur we linger too long in Spain: we muft go paft the Canaries and the Cape of Good Hope into the wide ocean, between fava and Sumatra, to Camion in China, there to employ our attention in thofe diftant parts.

OF the fifhes and birds which we meet with on our voyage, we ought to keep fome, the former in Spanifs fpirits, and the latter fuffed with tow, though their entire drying 
requires a long time and frequent care. Therr mannicr of living ought likewife as much as pofible to be obferved.

Tre minuteft animats ought not to be forgot. We frequently find fome which thine in water. The knowledge of thefe animals and of their place of abode may perhaps hereafter be as fure a mark to determine in what parts of the fea we are, as the trumper weed (Fucus maximus) together with the cape pigeons are an undoubted token that we begin to approach the Cape.

Ir is more advantageous (if circumftances allow of it) to go on fhore in Fava when we fail to, and not when we fail from, China; fince in the feafon of our return the rain ufually occafions many interruptions. We here meet with a collection of the molt magnificent productions of nature : the moft remarkable animals, the finet infects, the prettieft thells, the moft wondrous corals, the fcarceft plants, efpecially many forts of palm-trees, which might afford many a year's work for an admirer of nature. The civility of the inhabitants is no fmall encouragement to us: and we forget the fury of wild beaft, in confideration 
of the rarities of this ifland. We admire, and are aftonimed. The remarkable trade wind, which blows fouth-wett one half of the year, and north-eaft the other half (including the time of change), in the Chinefe fea, has obliged fome Swedifh fhips, which arrived after the fetting in of the contrary wind, to lie by half a year together at fava, or fome other ifland. If one attentive perfon thould be found among fo many people, the difadvantage arifing to the company from this delay would be balanced by enriching Natural Hiftory and other fciences. The Indian medicinal herbs, and other things which the Dutch pour in upon us from Eaft India, whofe native foil we are in general unacquainted with, would, at leaft, in part become more known: but the traveller cught firft to be acquainted with an apothecary's fhop, and the writers on Indian natural productions. It is worth enquiring, befides, whether the Dutch take in natural faltpetre as ballatt at fava, refine it, and afterwards fell it to us and to others at a great profit.

PAssing by Sumatra, we were all reminded of its gold mines, but probably may never have any opportunity to fee them. The inconfancy of the wind, the falling of the water, and 
s cangerous paffage between the neighbouring illands, forced us frequently to caft our anchor. When we weighed anchor again, we pulled up fuch a quantity of fea worms with it, as are otherwife difficult to be found. The Chincle fea is full of the fineft and moft curious fifhes, which may fometimes be procured drring the trade wind.

OrF entering Cbina, I remember the account a Srede gave me, who had failed to the eaft, and travelled from Bocca Tyger to Canton: this journey deferred all poffible care and expences, unlefs our eyes were prejudiced in farour of any other country; for we thalt fcarcely find fo careful an ceconomy of foil in any other place as in Cbina. The gathering of bones, hair, $\mathcal{E}^{2} c$. which we throw away, and the extreme but well-rewarded trouble they take in tranfplanting, are certain proofs of the induftry of the Chinefe, and of their laudable difpofition to cultivate their country. If travellers would permit me, I would give them the following advice: forget if you will your expences, but never forget the leaft particular of the ceconomy of the Cbinefe; for they regulate their ast according to nature, 
and modify it according to the fituation of the place.

ForEsIGHT is neceffary againf the fufpicion of the Cbincfe, and even the leaft opportunity ought not to be miffed. A filent company is here neceffary. An old interpreter would be of great ufe, if your finances allowed you to keep one. But with a people fo totally governed by felf-intereft, you feldom arrive at the truth by direct queftions.

WE bring the Porcellane clay to Sweden; but are we fure that the Cllinese give us a true fpecimen of that important manufacture? I either do not yet know this nation well, or I have great reafon to doubt it.

A PERSON who is able to bring them to. his own terms when they offer their goods to fale, can beft get the truth out of them unobferved, during the carrying on of the bargain. Such a merchant might, if he was befides acquainted with natural hiftory, be of double ufe to his country.

Perhaps the Porceliane is not manufactured at fuch a diftance from Canton as we are told 
it is. The old Porcellane, the ftone Porccllane; and the prefent Porcellinis, feem to be made in different places, and of different materials.

Do we know what the brown or red ware is made of? Would it be impoffible to get a little way into the country by means of money, and to be able to get a fight of fuch manufactures? Could we not get cotton (which is bought up in great quantities here by the Armenians) to Sweden by the way of Turkey? But we muft dwell no longer upon fuch fuppofitions.

WE may here get collections in all the kinga doms of nature. They fell birds, fifhes, fhells, and infects. They will alfo fupply you with trees; among which the Bambou tree, and the Clbind root, with many others, deferve to be brought to Swedsin. The country is adorned with the fineft trees and plants, and almoft all of them are very different from thofe of Sweden. But, to make ftill more accurate obfertations, fome courage is required, and a careful examination of all their accounts.

The quarry at the bon tower deferves a journey; though the ftones which are dug VOL, II. th there 


\section{Int of the Ufefulnes of Attention}

there are worked in ftone-cutters thops at Canton. There you may perhaps find another fort of ftone, below, in, or above, the ftrata of fand ftone. Even thofe who are not ufed to collect ftones, might enrich our Sruedifh cabinets of natural hiftory from hence; a piece of ftone of the fize of a chocolate-cake is eafily wrapped up in a piece of paper, on which the place may be marked where it was found. Species of the earths, fands, and clays, of fo diftant places, would likewife adorn our collections. You may likewife enquire at Canton about Ores, viz. gold ore, from Sumatra, copper ore from Fapan, Porcellane earth from the fame place, Tintenaque, Cbinefe gold ore, \&c.

MANY other articles there are, worthy our attention: but I need not try your patience any longer, Gentlemen ; and what is here omitted may be fupplied by the accuracy of the ! traveller.

I MUST once more mention fava and its neighbourhood, which we fee again on our return. St. Helena, an Englifh ifland, has formerly been a convenient refting place to us; Afcention likewife, where birds and fines are caught with little trouble: the former on the heaps 
heaps of ftones, and the latter when the water throws them on thore. Stones, earths, fands; and in a word the greateft part of what is to be met with here, are uncommon in other places. Ilikewife pafs orer Fayal, with the other Azores, of whofe natural curiofities, as far as I know, no fatisfactory account has been as yet given. It is worthy our trouble to enquire whether they there make a fort of indigo from another plant, bifides the Indigofer a tinctoria of the Indies. I have feen thefe illands, but without any hopes of getting on fhore. It is no wonder that I paffed them with regret: That which gives life to all f́ciences is; a defire of knowing more. 


\section{$\left[\begin{array}{lll}1 & 4 & \end{array}\right]$}

\section{T H E}

A N S W E R.

Given in the Name of the Roy al Aca Demy of Sciences, by their Prefident Mr. JOHN FREDERICK KR U GER.

\section{S I R,}

BELIEVE it is an undoubted truth, that

I the advantage or difadvantage of travel into foreign countries depends principally on the inclination and abilities of the travellers. To travel in order to acquire wifdom, is the moft dangerous of all undertakings, efpecially when the traveller is raw and unprincipled, and not animated by the pureft love of his country. The difadvantage would be but little, if the head of fuch a traveller could only return as empty as it fet out: for it would then comprehend only the lofs of the money fyent. But if his mind is filled with foreign follies, 
follies, the lofs is double: for the money is fpent, and our native virtues are adulterated by new-imported vices. This occafions a mo. ral evil, which grows more incurable from time to time, fince there are fo few that are confcious of its baneful influence.

A nation which does no honour to fcience, arts, and trade, can expect no hing but foreign fopperies from their travellers: for how can they be inquifitive in other countries about thofe things which are defpifed in their own? or, why fhould they with a great deal of trouble acquire fuch notions abroad, as will not be regarded or adopted at their return? And this is the principal reafon of the little benefit which Siveden has formerly reaped from its traveliers. But, fince fcience has been equally efteemed both by high and low, we can boaft of thofe travellers, whofe fole view has been to improve their knowledge by frefh experience. The more foreign nations endeavour to conceal any wife regulations, the more is their laudable defire of knowledge inflamed. And as it is difficult to conceal any thing from a quick-fighted and wife man; fo it has likewife but feldom happened, that connoiffeurs (the purpofe of whofe travels has been the im-

$$
\text { I. } 3
$$

provement 
550 The Anfwer of the Royal Academy.

provement of fciences) have returned without having obtained their aim. ${ }^{\circ}$ I even venture to fay, that as much as the ufelefs travels of our reftlefs youths have formerly proved to our difadvantage in trade, in regard to the balance of money with foreign nations; fo much has been our advantage of late, by means of the travels of fome Sredes into the moft diftant çountries.

THE difcoveries which have been made in natural hiftory, and the fcarce collections of foreign plants made by Kalm in Nortb-America, Haffelquift in Paleftine and Egypt, and Loef:ing in Spain and in the Spanifh parts of SouthAmerica, are of fuch a nature, that they are not to be found in foreign accounts of travels. It is therefore much to be regretted, that the two laft mentioned gentlemen finifhed their pilgrimage in this world fo unexpectedly, on the very travels they had undertaken for the fervice of fcience: a misfortune which cannot be remembered without regret, becaufe it has occafioned an almoft irreparable lofs, not only to Sweden, but to the whole learned world.

IF the Royal Academy had not made it a rule, Sir, to referve the praife of its friends, 


\section{The Anfwer of the Royal Academy. I5}

to a time which it always wihes may be as diftant as poffible; I hould find fufficient occafion here to tu:n my difcourfe upon the abilities you have thewn on your travels in foreign countries; but your own writings fufficiently explain my thoughts. Give me leave however to fay, that the public thankfully acknowledges the courage you have exerted amidit fo many difficulties, for the enlargement of knowledge; and reckons you among the fmall number of travellers, who have opened a field, (which before had never been attended to) and in a country too whofe natural hiftory has lain till this time in the greateft obfcurity.

Your excellent journal, the curious treatifes with which you have feveral times enriched the memoirs of the Royal Academy, and the fpeech which you have juft now pronounced, undoubtedly fhew, that I do not embellifh mine with flattery. It is now a long time fince you have acquired the friendthip of the Royal Academy; but fince it is defirous of obtaining your confidence more fully, and of employing that mature judgment (which you have by travel fo confiderably en-

$$
\text { I. } 4 \text { riched) }
$$


I52 The Anfwer of the Ryyal Academy.

riched), ic con'l find no better means to effect than by affi, ing you a place amidft its niv ist wafure whom I now offer you $\mathrm{my}$ carty congratulations. 


\section{A}

\section{$\begin{array}{llllll}V & O & Y & A & G & E\end{array}$}

$$
\text { T O }
$$

SURATTE, CHINA, \&c.

From the ift of April, 1750, to the 26 th of June, I 752 .

$$
\text { By O L O F T O R E E N, }
$$

CHAPLAIN to a Ship in the SWEDISH EAst INDIA Company's Service.

I N

A Series of L E T TERS

$\mathrm{T} O$

DOCTOR L INN 



\section{$[155]$}

$7 \mathrm{HE}$ author of the following letters, a

1 perfon of quick parts, tonk a refolution to leave Gotbenburgh in the quality of chaplain to an Eaft Indiaman. In order to qualify himfelf to make proper obfervations as a naturalift, whilft on this diftant voyage, he went to $U_{p f a l}$, that he might profit by the inftructions of the celebrated Linneus. On his voyage he collected many farce plants, which he prefented to his inftructor in natural hiftory; who named the Torenia Afatica after its difcoverer. After his return, he publithed in a feries of letters (from November the 2oth, $175^{2}$, to May the $3 \mathrm{~d}, 1753$ ) this account of his voyage; but died near Nafinge in Sweden, on the 17 th of Auguft, 1753. 



\section{TOREEN'S VOYAGE}

\section{T O}

SURATTE, CHINA, \&c.

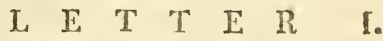

\section{SIR,}

YOU will be fo kind as to excufe my not I. complying fooner with your defire of feeing fome account of my Eafi India voyage. The caufes of my delay have been owing to a neceffary attendance on my own affairs and thofe of my family, and the bad ftate of my health. If what occurs to my memory can 'ferve to amufe you in fome of your leifure hours, I hall have more than fufficient reafon to think my pains well beftowed. 
THE I $\mathrm{f}$ of April we fet fail on-board the fhip cailed The Gotbic Lion, after the weft wind had continued to blow for five months together at $\mathrm{Go}_{0}$ thenburgh, and had almoft induced us to believa that there is a trade-wind in the Scaggerac Sea. The wind made April fools of us ${ }^{a}$; for we were forced to return before Skagen, and to anchor at Rifwefiol.

The 8th of April we had better fuccers. A fairer wind than the former helped us out of this corner, and we continued our voyage in company with many other thips. We met with nothing extraordinary, except a Danifh fhip called The Hereditary Prince, which was bound for China, and had left Copenhagen the $4^{\text {th }}$ of December, I 749; the had therefore a very perverfe wind from the time of her departure.

$\mathrm{T}_{\mathrm{HE}}$ high waves of the German Ocean, and the Flemifh Coafts, hindered us from reaching Dunkirk before the igth of April. I did not go on thore, for but few had that liberty al-

2 It hence appears that the fame practical wit of duping people on the firlt of April obtains in Sweden, as among our wags in England:

lowed. 
lowed them. But the fituation of the place naturally brought to my mind the reafons why England would not permit it to continue fortified.

THE town is fituated on an open harbour: the entrance is difficult; and the pilot afked fix hundred French livres for his trouble. But befides that the privateers in time of war can do a great deal of harm from hence, it is very conveniently fituated for the Englif fmugglers, who run the French liqueurs, \&cc. over to England, where there is a high duty laid upon them. Not to mention that the Aufrian $\mathrm{Ne}$ therlands can be provided from this place, as a free port, in great plenty, to the difadvantage of a neighbouring nation.

$\mathrm{F}_{\mathrm{ROM}}$ hence we failed, the $22 \mathrm{~d}$ of April, with fo good a wind that we were able to anchor on the fouth fide of Madeira, at Funcbal, the $4^{\text {th }}$ of May. The hip happened to be fo ftationed that the country exhibited the fineft profpect I ever faw.

IT rifes like an amphitheatre: below is adorned with fine fields, gardens, and vineyards, to which nature has given an advan-

tageous 


\section{TOREEN'S VOYAGE.}

tageous fituation, both in regard to the rifing and fetting fun: at the top are fteep hills covered with trees. Here and there are fome country-feats, which make the profpect-ftill more delightful: but below, as in a center, is the city of Funchal.

IF you go on fhore, you have a battery at the water's edge on the right, and a caftle or the left. Whoever lands here muft carefully decline meddling with the tobacco-trade, in the fame manner as in Portugal; a fingle roll of tobacco is enough to bring both men and fhip into danger. The beft thing is, that the cuttom-houfe-officers are fatisfied with any excufe almont, if it is but plaufible. The town has a rampart, within it a cafle, and befides 'this a commanding fortrefs on a rifing ground: but all thefe are without a terreplein, have only high banquets and very fhort flanks, as is ufual when they are to be perpendicular to the curtains.

THE houfes are pretty good, and three ftories high, but the loweft are generally uninhabited. I faw no windows in private houfes, but inftead of them, iron grates. 


\section{F U N C H A L. 1750. I6I}

THE many proceflions hindered me from looking about as much as I could have wifhed. I once faw the Francifcan monaftery. It is not a regular building, but convenient, and thews that it has large revenues. The good fathers had retired from the world like the moufe into the cheefe. I did not fee one that had the leaft employment. It is eafy to imagine that fo fine a country in the hands of the Portugueze muft have nunneries and colleges of $j e-$ fuits.

My landlord, Mr. Timothy Doweling, affured me that he would willingly ferve the Szredifts Academy of Sciences in what he could procure from Madeira or Brafll; and it might be worth while to put him in mind of his pronife, fince he inim?elf is curious. He had found fome petrefactions, and a plant which he would have to be the Laurus which crowned the heads of the ancient Romans ${ }^{b}$. The particular plants which I faw on my fhort walks were:

A Cactus, on a fteep hill. When this ber gins to ripen, I think it might be ufeful to ob-

b This is the Alexandrian Laurel. VoL. II. II Serve 


\section{TOREEN'S VOYAGE.}

ferve with a good microfcope whether the pollen goes down the whole fylus or not.

Mufa Paradifaca, which our Swediff fail. ors, together with the Malacca people, and the Dutch, call Pifang, the Englifh Plantaintree, and the Portugucze Bananas, bore larger fruit here than I have feen any where elfe; but a very lively imagination is required to fee the figure of a crofs in a plantain-tree.

\section{Pafiflora grew without the inclofures.}

Some Chefnut-trees were preferved on account of their great age and fine thade.

THE grapes of this ifland (which is fcarce above ten Sruedifh miles ${ }^{c}$ round) yield, as ! was told, between 30,000 and 50,000 pipes of wine.

Ir would not be accurate to judge of any two nations by two of their cities alone; but fince I have been at Cadiz and at Funchal, the difference to me feemed greater than could have been fuppofed, confidering their religion, climate, neighbourhood, and language. A

\& See note, vol. I. p. 2. 


\section{FU N C H A L. 1750. 163}

Sermor at Cadiz is tawny: if he is not a monk, he wears a coat reaching to the feet, a linen cap, and a hat upon it; every thing is folemn: but in Funchal they had fine complexions, full faces, and did not affect fo much gravity. Their drefs was Frencl, except the long black coats and furtouts.

The Portugueze ladies are fcarce ever in the ftrcets; but as far as could be difcerned when they opened their windows in order to fee and to be feen, they difplayed a fine fair complexion and lively eyes. I think I faw five at Cadiz, and thefe were thin and tawny. I obferved that the Virgin Mary had correfpondent airs, complexions, and thape in her pictures; and I judged from thence, that this was the tafte of the nation with regard to beauty.

AfTer we had provided ourfelves with wet and dry provifions, we fet fail, the 1 Ith of May, and made the beft ufe of the uniform weather and wind that fubfift between Africa and America, which forward the voyage to the Eaft Indies with more expedition than that to Hudfon's Bay and the Nortb Cape; becaufe the wind in thofe latitudes is more changeable.

$$
\text { M } 2 \text { South }
$$




\section{TOREEN'S VOYAGE.}

South of Brafil we were forced to turn eaft. We had here, for fome days together, a fea which would have frightened any one whowas not ufed to it. I fhould not exaggerate more than fome poets, if I fay, that in one moment we were afraid of pulling down the Magellan clouds from the lkies with our top-fails, and in another of crufhing Neptune and the 'Tritons with the keel of our fhip. It will eafily be conceived by thofe who have been at fea, or know how the failors meafure ilic wind, with what force it blew, when I fay that we ran eight knots with a reefed fore and main-fail, though the fhip was deeply laden, and none of the beft failors.

Cape Pigeons are a fpecies of birds which are frequently feen in great numbers in thefe latitudes. Perhaps they get their name from flying in a circle, and the refemblance they bear to pigeons in regard to the fize and wings. I could not examine them near enough, but took them to be Procellaria Capenjis. Their colour is like damafk, white and biack; for which reafon the Englifl call them Pintadobirds, from the Spani/h. When the wind was high, we fometimes fiw the lefs dark-brown " Storm-finch, which is ciiled Malcfit by the Por- 


\section{ST. JOA N A. 1750. I 65}

sugueze, and Petrel or Foul-zueather-bird in Englifs; it feemed larger than that which I faw in $174^{8}$ in the German Ocean (Procellaria aquinoctialis\}.

Be Low the Cape of Good Hope the waves frequently dafhed over our deck, as is common in thefe parts. Once they threw fomewhat thining in the dark upon the deck; I ran to it, and caught up this feeming curiofity; but upon a clofer examination, found it was enly a little crab. 


\section{$\begin{array}{lllllll}L & E & T & T & E & R & \text { II. }\end{array}$}

BETWEEN Africa and Madagafcar we $B$ found an animalcule in the water, which, whilft living in that element, refembled a worm; but when it was taken out and laid on a plate with water, all its articulations came afunder, and each moved by itfelf. We likewife caught a By-the-ruind-failor d (Holothuria phyfalis). Befides this, we likewife took an unufual fea animal of a llimy fubftance, which is difficult to defcribe, of which Mr. Braad has probably fent you a drawing.

We had already feen Madagafcar, Mafota, Mobilla, and the high Comaro, not without a longing defire of getting on thore; when we arrived in the Nortb-bay of St. Foanna, on the I 6 th of Auguft.

THis country feems to be one of the molt agreeable on the whole earth: and not only myfelf, but likewife far more experienced

d This is the name which the Swedes give to this kind of Holotburia. F. 
twavellers are of this opinion. The ifland is hilly and uneven; but this inequality only adds to its beauty, fince both the little hills and fteep mountains are covered with verdure. Cocoa-nuts, plaintain-trees, pine-apples, pomegranates, papayas, and other fruits, are in great plenty here. Oxen with humps on the fore-part of their backs, goats with pendent ears, common and Guinea hens, are fold at very reafonable prices.

THE inhabitants are Mabometans, and are defcended from the African Arabians; but they are very civil, and more honeft than any one could expect. As fome of our people could fpeak Englifh, they received us with their ufual compliment: "Englifsmen, come; all of " one brother, come." They are very different in colour. The chief officer in the village where we landed was almoft quite black, but his nephew was only fomewhat tawny: and the fame difference is to be met with among the reft. Their hair curls (as the negroes) like wool, and will hardly become ftraight by cutting. They were but poorly drefled: a turban was very rare among them; and a great many could hardly afford to cover what ought to be covered. 
WE here caught an animal (Lcmur catta Linn. or Macauco of Edwards) whofe colour was reddifh, but its back of a greyifh-brown: about the ears it looked like a fox: the tail was grey, with black rings, about one third part longer than the body, and is fet an end by the animal like that of a fquirrel; but has fhorter hair : the fnout was pointed. (The reafon why I give this defcription, though fo incomplete, is, becaufe I fear that fome might miftake it for a fpecies of ape, to which the feet would lead one: for it has five flat round nails, but the thumb on the hind-feet is very large, and the firft finger had a tapering nail c\%. The tccth were, as far as I could fee, not like thofe of monkies; for I obferved no canine ones: and when there was more than one ferrated primary tooth in the upper-jaw, there were at leaft five little ones. Thus far I proceeded in my obfervations when it bit me. I was not prefent when it died and was thrown over-board. In curiofity and reftleffnefs it was like a monkey; but it was more fhy, not fo

e I think it hath not been obferved that the fecond toe of the hind-foot of Lemur catta has a bird's claw. This is perhaps a new fpecies, Linn. 
docile, nor fo unfeafonably officious. It lives in Madegafcar and Mauritius. I might have had opportunity on this voyage of examining feveral more exacly ; but they cannot be procured without paying for them.

THE moft naufeous and troublefome animals are the lizards, which are, without any exag geration, innumerable, and much more frequent than in Madeira: in one cocoa-tree of twenty yards high you may fee at leaft fixty of them. In fome places I could not advance a ftep without ftirring whole troops of them, which fculked under the fallen leaves.

THE boats in this country are commonly fingle trees made hollow, and round at the bottom; and they have two out-riggers, which, by means of a board pointed at both ends fáftened to them, prevent them from overfetting.

THE zoth of Auguft, being provided with meat and water, we continued our voyage without hindrance; except that we were under arms on account of fome Portugueze ve?fels. 
THE 16th of September we anchored in the harbour of Suratte, about a Swedifls mile from the thore, becaufe the fands prevented our nearer approach. It was fome time before the trade in Sruedifh cottons could be fettled with the people of the country. But this was more the fault of the Chriftians than of the Mabometans. Perhaps the owners of the Szeedifh iron, which was already laid up in our neighbours ftorehoufes, could not relifh that which was juft arrived, becaufe it was carried on a Swedifts keel. The old accufation of our being pirates, was too ftale to make any impreffion on the nabob. The Arabians had applied this opprobrious appellation to the Portuguefe, thefe made ufe of it againft the Dutch, who it is faid employed it againit the Engli/h. After feveral efforts, the gentlemen and Myne beeren ${ }^{f}$ at laft refpected his Majefty's pafs, at leaft they left us quite at liberty.

THE fea runs commonly very high both in ebbing and flowing at this place, and is full of

\& Mr. Toreen feems to mean the factors of the Englifh and Dutch Eaft India companies here; Myne beeren fignifies Gentlemen in $D_{u t c h}$. F. 


\section{SUR A T T E. 1750. I I I}

fea-worms, which not only keep above water, but likewife eat the wood of the anchor at the bottom of the fea; and if their piercers were alfo frong enough to penetrate the paper, pitch, and hair, which compofe the theathing on the outfide of the fhips, they would foon fink them.

THE neareft land is every where very flat; and confitts of alternate plains and woods. On the fields millet was commonly fown about this time. The cocoa-trees are almoft facred here; their juice is drawn off by tapping, and therefore they bear no fruit.

Banian-tree (Ficus Indica) is that peculiar tree which thoots new roots from its branches which bend down to the earth. It feems to have obtained this name, becaufe thefe idolaters look upon it as facred. Perhaps, without this providential care, this fort of trees might be entirely deftroyed. I obferved very attentively, but could not find the leaft remains of fruit, flowers, or roots. It feems to grow but flowly; and I thinls the high broad tree which ferves as a fea mark on the harbour is very old. It would have been extremely hazardous at the time that we were here to have undertaker 
I72 TOREEN'S VOYAGE.

raken botanical excurfions; for the attacks of the Marattoes and other nations were to be feared even before the gates of Suratte. What I was able to fnatch up there in other places, (as the dog does the water of the Nile) is undoubtedly by this time in your hands.

$\mathrm{T}$ н $\mathrm{E}$ magnificent tombs in the country built with domes (which manner of architecture the Mabometans greatly afiect) did not feem fo extraordinary, when one recollects that pride fubfifts even beyond this life. Some exceeding deep wells, which were dug at a great expence, and with a great deal of labour, and had very good walls about them, deferved much more to bear the name of thofe who had thus fupplied the inhabitants with fo neceffary an elemert. The water was drawn out of them by a rope and wheel, worked by means of two oxen; being then poured into leathern bags, it is brought to town on buffaloes and fold there.

THE foil is none of the beft. The earth proper for vegetation compofes but a thin ftratum: below is very good potters clay, which is of good ufe to the inhabitants, who, 


\section{S U R A T T E. $175^{\circ}$}

like other Afratick nations, make much ufe of earthen ware.

After rowing or failing from the anchoring-place, about three Swedi/h miles, you come on the river Tapti or Tapta to the city of Suratte. The thing that firft ftrikes the eye is a confiderable building, called the caftle. It has formerly had four baftions, one of which is tumbled down; and the bad wall which has been built inftead of it feems ready to follow its fate. It has a good number of cannons on feveral terraces; but their muzzles are dropping, and they are fo ill ranged that often an eighteen pounder ftands clofe by a fix pounder.

ThE caftle is the centre of a low wall, which makes almont a femicircle, and has angular baftions, and a diry ditch, which includes the city. Thefe are again furrounded by the fuburbs, which have the fame kind of fortification, and are faid to contain above a hundred thoufand inhabitants.

The fearch at the gate for the firft time feemed fomewhat rigorous to us, becaufe the cuftom-houfe officer would know how much 
174 TOREEN'S VOYAGE.

money we had in our pockets: for I was told there is a tax per cent. on the import of money. We efcaped this tax; however, I could not fuficiently wonder at fuch odd politics. 


\section{$\begin{array}{lllllll}L & E & T & T & E & R & \text { III. }\end{array}$}

$7 \mathrm{HE}$ ftreets of Suratte are irregular, and

1 many fine buildings have been deftroyed by fire, which, according to the Mabometan doctrine of predeftination, it is in vain to withftand. Street-pavements are unufual here; and though the owners and tenants of houfes every day fprinkle the ftreet before their doors, yet the duft is frequently troublefome. But hould the ftreets be paved it would be in vain, for the rain which fometimes continues for half a year together would tear every thing up, and wafh the whole work away. The houfes are tolerably well built of bricks, mixed with wooden beams, but without braces: in the infide they are plaftered with a fine white cement, which renders them as fmooth as if they had been rubbed with pumice-ftone. I was told that the cement was made of pounded egg-Thells, and the dregs of fugar. Captain Shierman related, that he and the other captives had been forced to pound lime mixed with fugar dregs for the pirate Angria, which was probably for this ufe. In the lower fto- 


\section{TOREEN'S VOYAGE.}

ries are no windows, and but few in the upper. In my opinion this is done merely through jealoufy, and not out of any well-grounded fear of thieves; for he who fteals five bottles full of rofewater is punifhed by the lofs of both his hands, which punifhment muft probably deter from the commiffion of this crime.

I HAD little opportunity of feeing the difpofitions of their houfes, further than in the Swedif factory. This houfe was exactly quadrangular, and had fome beds with flowers inftead of a yard, in which a fine Altha frutex. (Hibifcus Surattenfis) was in bloffom towards the end of Fanuary. Round about it were ftone walks of two fteps high, and on the four fides as many halls, open towards the yard, with niches on the other three walls reaching from the roof within three feet of the floor. In the corners are bed chambers, or the kitchen. Thofe who live in the loweft ftory, have air-holes in the walls for their refrefhment in the great heat. At the top is a terrace paved with ftones, from which you have a fine profpect. Cifterns and artificial fountains are confidered as the greateft luxury, partly on account of their refrefhing coolnefs, and partly on ascount of the necefity of their ablutions. 
The fair-cafes are narrow and the fteps high; as for the reft, the foundation is extremely expenfive. We had in our quarters two wells twenty-four feet deep, neither of which afforded water that was diinkable. Unider the Swedifh latti or warchoufe was a tank b, that was arched över.

THEIR architecture is neither borroted from the Grecks nor Italians; yet there is tafte and an agreeable proportion in their columns. Some ornaments on the capital and pedeftal do not feem to be in the right places; but they have fuch confidence in their arcliteeture, that they would make one believe that an whole building is fupported by leaves or feathers. The Indian architects have proved by the tomb of baron Rheede von Drakenzicin ${ }^{\mathrm{h}}$, that a building may look majeftic without being either of the Corinthian or Tufcan order. Englifhmen have fuch funcrals here as a prince would not be afhamed of.

THE intrabitants are for the moft part of three cafts, of which the Malabarian heathens are the firft, which are called Gentives, Gen-

8 A refervoir of water.

${ }^{n}$ This is the author of the celebrated book, Hortus Indicus Maialcaricus. iz rol. in follo.

VOL. II. 


\section{TOREEN'S VOYAGE。}

toos, or Geniiles. Thefe are the moft ancient inhabitants of the country, and divide themfelves, as is well known, into certain principal families, each of which has its peculiar trade. The Bramins and Banians religiouny obferve the law not to kill any thing which has life and fenfation. I have feen them make the mof moving petitions, in farour of loathfome sermin. The foldiers are not fo tender, even towards their fellow, creatures.

Tirotgrif the Gentcos cat nothing but milk, butter, and vegetables, yet they are rather fat. I have feen Bramins and Banians with very prominent bellies. Their perfons are of a middle fize, upright, and of an eafy carriage; they lave regular features, and an agreeable air, but are tawny.

THÉIR Women are generally very little, thickfet, and brown; I was told they marry early, but foon grow old. Their drefs is fomewhat fingular: befides that their ears are quite fult of rings, they have a ring with a ruby or garnet and two pearls in their left noftrils: a great number of rings are worn on the arms, both above and below the elbow; they have great filver fet.ers awove the'fect; and almot 


\section{S U R A T T E. I750.}

on every toe a ring of the fame metal. Their half-jacket covers no more than the breaft; $t s$ conceal the lower parts, they tie a piece of ftuff (generally red-ftriped) about their middle, turn the two ends through between their legs, and faften them before. On the head they have a cloth of the fame ftuff, which goes over the left and under the right arm, and is faftened to the girdle. All the reft is naked. They go fo upright, that even a dancing mafter could not give them a better air. Perhaps this erect carriage is occafioned by their carrying water every day from the river, on their heads. A Gentoo woman can carry three pots one above another, without holding them with her hands, go backwards and forwards with them, turn about, ftand and hold converfation, \& $\mathrm{x}$. Whether the ladies of quality and the rich are obliged to fetch their own water, I am not certain; however I have feen fome coming with their po:s, for the value of whofe rings many a good farm might have been bought in our country. Their virtue is fufpected by many, becaufe all the dancing women of the Mogul empire are taken out of this nation.

I cour $\mathrm{D}$ not fee their pagoda and religious ceremonies, but lobferved their morning prayer 


\section{TOREEN'S VUYAGE.}

in the river. They were obliged to wafh themfelves before this ceremony, clean their mouths, and with their faces towards the fun fay a prayer. They ufe rofaries for this purpofe, as is ufual in all countries where it is laid down for a principle of religion, that the repetition of a certain number of prayers will atone for any offence. The Gentoos fay their prayers on their fingers, beginning at the mott extreme joint of the little finger, and counting on downwards; when they have gone over all the fingers in this manner, they lay both their hands flat together, bow before the fun, and then get up and are painted by a Bramin.

THE Bramins themfelves have fome crofs ftrokes of antes over the forebead, with which they fometimes paint their whole body. The Banians have generally a red fpot juft above the nofe, about the fize of a filver two pence, from which two yellot ftrokes run down, and on each flap of the ear is a yellow fpot.

WHEN they carry their dead, they run in full career, and cry Beyram Ramibolu, which, as I liave been told, fignifies, My brettoren; call upon Rama. The corpfes are burnt by the rivet fide without the city, but the widow is not o.liged 
S UR A T T E. 1750. 18 I

obliged to follow her husband into the fire. If we confider the great number of corpfes that are burnt, it muft neceffarily follow that many thoufand of Gentoos live in Suratit. They have likewife Santons, or living faints, who diftinguifh themfelves from the multitude, and endeavour to make themfelves pleafing to Ram and his brothers, by their ridiculous behaviour. Thofe fellows which Bernier has defcribed and painted in all forts of conftrained poftures, I have not feen; but you frequently meet with fome who walk about more than half naked, and twift their long hair about their head in form of a turban, which muft be very troublefome in this country. I once faw a novice of this order, begging in a very fingular way. He placed himfelf before a hop, where he did nothing but ftamp againft the ground, and after he had very patiently lifted up and fet down one foot after another, he quietly devoured the victuals he had received. It is peculiar that the hair of thefe fellows grows pale and turns itraw-coloured; but I believe that they make it fo by art; for thore Mabometan Santons who do not cut their hair, preferve their black complexions, and have befides the advantage that they look like devils of the firft order, for their hair ftands an end like

$$
N^{\top} \text { a juniper }
$$


182 TOREEN'S VOYAGE.

a juniper bufh on their heads. It is faid the B amins have many curious fecrets; efpecially it is here looked upon as almoft certain, that the renowned Pedra de Cobra is a compofition known alone to them : and it may be that the Pedra de Goa or Gaspar Antonio, and Pedra. de Porco or fwine, muft come from the fame hands. If their ceremonies are not fufficient to maintain a whole caft or tribe, they feek their livelihood another way. For this reafor Bramins fometimes enter into the fervice of rich Banians: yet they keep their privilege; for the mafter is not allowed to touch the rice which his fervant is to eat, becaufe the latter would become impure by it, 


\section{SU RATTE. $\$ 750 . \quad 183$}

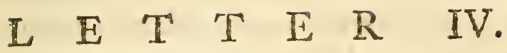

\section{THE Partbians or Perfees (who are}

1 defcended from the ancient Perficins) are the fecond nation which lives here. They have been driven out of Perfia long fince, according to Hamilton's new account of Eaft India. They adore the fire, the fun, the moon, and the flars. A Perfec cannot be perfuaded to put out a candle any other way than by blowing. I obferved once a little boy, who fate a great while mumbling I know not what orer a burning candle-fnuff, which was purpofely thrown on the ground: he fnapt his fingers, and continued this till the latt fpark was extinguifhed. They ought not to be called $\mathrm{G} a$ fres, becaufe Gour, Goufe, Guebre, or Cafre, fignifies an heretic, unbeliever, or heathen. They have the whitent skins of any among the natives; are lively, indefatigable, and are generally employed in the meaneft offices by the Europeans, induced perbaps to undertake then through necefinty; for they are more opprefied than the Gentoos, get into ro ptaces of truft, and have not the refources which avail

$$
\text { N } 4
$$




\section{TOREEN'S VOYAGE.}

the Banians, namely, a thorough experience in a thoufand forts of little arts. Their women haye been found to be lefs corrupted than molt others in India.

IN the fate they are in, onewould little exnea divifions among them in religious matters. INeverthele's there was one of them who had read wiore than the others, and had found out that they did not celebrate the new year at: the due time. He got a number of foilowers: but met with a great deal of vexation from the oppofite party. And this is nothing unconmon; for formerly the difciples of Thomas: Aquinas and of Duins Scotus could hardly ever: part without cufing and bosing. There was a time when a ferw was preferred to an Arminian; and a Siamefe to a Janfenift : fome reverend fathers will overlook many failings in. a: Cbinefe, and yet will excommunicate any one who differs from them in opinion, with regard to the conception of the Virgin lifiry.

THE third caft of people who frequent Stlratte are the Mabometans, or rather, as the failors call them, Moors, which may be contracted from Mogors, or Perfians. Their colour is a medium between the other two. 


\section{S U R A T T. 1750.}

Their religion is the reigning one, efpecially that fect which honors Omar. But Ali cannot be without'a great many followers here; for at a proceffion which was undertaken the 26 th of November, in honour of the two lalt Perfian Imams, I think I faw at leaft two thoufand men. At this ceremony a great many faquirs or begging friars were prefent, dreffed in white jackets, to which were fewed feveral rags of different colors, and a cap refembling a fugar loaf. The Dervifes generally officiated in the mofques and on other occafrons. I obferved a certain Dervife who was exceedingly well acquainted with the ceremonial part, and who was ordered to undertake a pilgrimage to the graves of the deceafed Inams. He fauntered all the way along, and had befides his difciples feveral others abour him, who beat a fort of drum, and fung la allah, \&c. along with it. I faw a Santon who feemed to deferve a good thrafhing for his fanctity. He did penance by going about the ftreets fark naked. He was by no means thunined; but on the contrary had always a severend Mabometan with him, who received the alms and kept them for him. 


\section{I86 TOREEN'S VOYAGE.}

BESIDES the aforcmentioned clothes of the Bramins and Gentoo women, they are almoft all of them dreffed in white cotton about the body. The parts of their drefs are a pair of llippers which are pulled off ar the door; a pair of trowfers; a fhort flirt which is open before, and above the breeches; and over this a coat reaching to the feet, which fits clofe to the body, and has folds below like a petticoat; it has long fleeves, which fold over the hands. 'The Mcbammedans and Heatbens obServe this difference, that the former tie the fore part of their coat below the right, and the latter below the left arm. They tie a girdle about their waifts of the fame ftuff of which the coat is made, or fometimes of richer; and in it they have a precious knife, or, according to the difference of cuftoms, a dagger. The Perjees have a fring below the girdle, which ieems to be a part of their religion; for at Dombes (a village near Suratte) I faw a Perfee, who, before he faluted his guefts, meafured his forchead with this fring, and made a bow to the moon.

Tut turban is of all colours; the grien here denotes nothing extraordinary in the rank of 


\section{S U IFA T T E. 1750.}

the rank of the wearer. A turban of Suratte is eafily diftinguifhed from the Perfion and Arabian, for though it requires above thirty yards of cloth, it fits very neatly on the head, except a great bolfter which comes juft over the right eye.

THE drefs of the women who are feen in the freets differs from the drefs of the men in regard to the coats, which are open before, and cannot be thrown back to the other fide; and their breeches reach down to the very feet. They only throw a loofe cloth over the head and fhoulders. Poor people of both fexes wear both thorter and fcantier clothes.

Вотн fexes falute in the fame manner, namely, they lay the hand on the forehead or on the head. Some fay Salam or Sala Maleck with it. If they intend to exprefs fubmifion, they firf lay their hand on the ground or floor, and then on the left breaft, and at lafe on the head. On the aforementioned feftival in honor of the Perfian martyrs, I faw another method of faluting their friends; they firft put our heads on their left fhoulder, then on the right, and then again on the 


\section{TOREEN'S VOYAGE.}

left; then we placed their hands between ours, and put them at lait so our foreheads.

The Gentoos make ufe of the Malabaric language; the Moors reak a dialect of the Arabick, which the Perfees mutt learn; for which reafon there are but few who know the language of their anceftors. As for other people, fome broken Portugueze is fufficient in all the trading towns of the fouthern $A / 2 a$. They eat fitting on a mat, fpread on the floor; and lay the table-cloth on the fame place. Rice ferves them inftead of bread, and is either boiled in pots, or kneaded and baked on plates, like the thin bread ufual in Babus

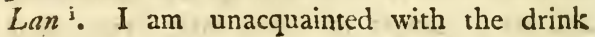
made ufe of by the rich; but the common people latisfy their thirft with water; if they will have any thing ftronger, they procure toddy (or the juice drawn out of the cocoatree) at a very confiderable price. Befides this, according to the account of Bonaventura, the rcots of millet will likewife intoxicate. A fingular fcruple fometimes hinders thefe people from eating with others, out of the fame dilb. A Mabometan can make a bargain of a hundred

1 A provirse in Nervigy on the Sespgers. F. 
thoufand rupees with a Banian; yet he cannos eat with him, nor go home with him: All the reffels which a Bramin has in his kitclea are facred, and muft not be touched by any one that does not belong to that caft. An old complaifant Perfee woman, who gave us fome milk as we travelled by, would not let her bottle come within a quarter of a yard of our glars.

THEY have flefh in plenty, but fuch proba. bly as is not very wholefome, efpecially to thofe who come on thore from long fez voyages; for, if they indulge their appetites; they are fubject to vomitings and diarrhœas, and are in danger of lofing their lives. It is probable that Brama, or whoever at firft gave laws to the Gentoos, had difcorered that thefe meats were very untholefome to the Alalaba. rians. Mabomet found his account in the frequent ablations, which in fome cafes are indifpenfably necetlary, in order to prevent the chopping and parching of the fkin; and perhaps worfe accidents. If you go in the morn: ing into the fuburbs and lanes, you very foon fee how bufy thefe people are in wafhing the children with the left hand.

BESIDES 
BESIDES the aforementioned difeafe, fevers frequently attack Europeansw The French at firft loft a great many men by this diforder, and were at laft (according to their own account) obliged to have recourfe to the phyficians of this country, who reject the ufe of bleeding and of tamarinds in agues. Tamarinds are not half fo much in ufe in Eaft. India as in Europe. The red-dog is a difeafe which afficts almoft all foreigners in hot countries, cfpecially if they refide near the fhore, at the time when it is hotteft. This diftemper difcovers itfelf by red fpots which look like mealles, itch and prickle, and then become little bladders, which, when they vanifh, take the fin away along with them.

Tun friction ufed among the ancients feems to have been rery rational. A perfon of fome confequence in Suratie is always rubbed at night by his fervants, as an expedient of great ufe to promote the circulation of the blood.

TuEIR mufic is but very mean. Italian pieces you are fure not to hear of in this country ; but inftead of it, the noife of brafenbafons and little drums with one or two bottoms. 
roms. Their wind infruments are a fort of ftraight trumpets, four or five Swedifl ells long, which make a bleating found. Sometimes they-make ufe of a great horn in form of an $S$, which is however only played upon when the nabob or fome other man of quality is coming. The reveille was played upon a flagelet from the caftle. Guittars and fiddles were the inftruments of beggars, who begged in verfe, and accompanied them with vocal mufic. A war-like mufic is generally in ufe among the fouthern Afaticks, and this they want very much; for fofter tunes would make them more effeminate. Perhaps the Spartans had more than meer cuftom in view when they broke a ftring of the lyre which was abore the ufual number.

Their jugglers are not to be compared with thofe of China, except that they can fafinate in fuch a manner the Cobra de Capello (Coluber Naja Linn.) as to make it dancek. When the Mloors or other people have a mind to divert themfel;es according to the cuftom

${ }^{k}$ Kempferi Anan. Exotic. Fafcic. III. Óbr. ix. p. $56_{5}-$ 573, gives the molt credible and curious account of thefe tricks with the Cobra de Cafollow. Fo 


\section{TOREEN'S VOYAGE.}

of the country, they get a band of dancing women (for fuch is their name though they ftand ftill for the greateft part), who fing amorous fongs, with all forts of wanton geftures. Such a diverfion is often very troublefome to the neighbourhood, becaufe the infruments generally ufed at it will allow of no reft all the night.

I HAD feen no blue eyes either in the fouthern parts of Europe, or in Afia, till I found an Arabian at Suratte whore irides were not the common colour. I was told, that they were not efteemed in feraglios, perhaps becaufe they do not fparkle fo well; but dark cyes feldom look ferious.

THE arms of the Moors confift of mulkets with matches, bows, fabres, and daggers, the latter of which have a fingular thape: for the handle confints of two pieces of iron, which are fo far diftant as eafily to afford room for the hand to take hold of two crofs iron bars. The breadth of the blade, near the handle, is three fingers, or about two inches threequarters, and its length one quarter and half a quarter, or thirteen inches and a half. They like glittering arms and filver hilted fabres. Befides 


\section{S URA T T E. I750. 193}

Befides this, they have a round hollow fnield of buffalo fkin, a yard in diameter. The pions, or the people which go before men of rank in this country both for parade and fecurity, carry their fwords drawn, and their thields on the left arm.

$T_{H E}$ advantageous fituation of Suratte for trade appears from a map. The Arabian merchandize can here be very conveniently bartered againft the Indian and Cbinefe manufactured goods. But it is unlucky that the government is not ftable : the court is inactive at Delbi, while the governors at Surattc fight with each other.

The continual rains from May to September frequently change the fands, and the gulph is as full of pirates as the Baltick Sca was in the time of the Wickinger. Thefe three obftructions, together with fome others, have induced fome Europeans to have entertained fanguine hopes of getting this trade to themfelves; which would not be difficult, if there was toleration in religious matters, if the government was lefs defpotic, and the pirates were oppofed with more vigor, who, it is faid, have been purpofely neglected by the powers

VOL. II.

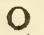

which 


\section{TOREEN'S VOYAGE.}

which wanted to be fovereign in the eaftern and weftern oceans. But, notwithftanding this, many thoufand rupees pafs through the hands of the merchanss for Perfian and Chinefe filks, and white ftriped checkered cottons; likewife for camboya, agates, and Ceylon ftones, which are alway's foft; alfo for diamonds from Vija Poor and Golconda, and for many other goods. The Moors get a confiderable part of the profit, becaufe they enjoy the greateft protection from the government; but the Banians are the moft cunning merchants in all the world, which is nothing extraordinary, fince they have for a long fpace of time improred and derived down their fkill in mercantile affairs from father to fon. If what I have been told is true, they muft certainly be enormous ufurers: for they are faid to take one rupee intereft per month for nine rupees. Hence it is certainly not to be wondered at that Shab Abbas fhould expell them out of 1 p paban, in order to admit a far more honeft people, namely, the Armenians. It is pretty plain that the merchants have opportunities of gaining confiderable fortunes here, when one of them had nineteen thips at fea on his own account: but it was looked. upon by the Mabometans as a clear proof of the 


\section{S URATTE. $175^{\circ}$.}

the invincible power of fate, that he could never get to the twentieth. He is faid to have been poffeffed of a whole arip, that is, 1000 millions of rupees; which is an incredible fum, when you obferve that the invafion of the Mogul's empire by Nadir Sbab did not coft more, when every thing which can be eftimated by money was taken into the account.

Of the weights here ufual, a candee, or candy, is twenty maunds, and a maund is forty feer ${ }^{1}$ : a fecr is little different from a Swedifh grocery pound. Their lefs weights I could not get an exact knowledge of, but gold and filver they weigh by the feeds of the Abrus precatorius $^{\mathrm{m}}$, becaufe they are light, hard, and durable. Their moft ufual coin is the rupec, which weighs about twenty-one pennyweights; and it is faid, its filver is finer than that of the piaftres, on which account the Cbinefe take them fooner than piaftres ${ }^{\mathrm{n}}$. A

1 One maund is thirty-feven pounds and 2 half, and one candy is fix hundred wt. two-thirds. See Rolt's Dictionary, under the article of weight. F.

m Formerly a Glycine, but fince changed by Lianasus in Ed. 12th of his Syfema Naturce. F.

- A rupee is about $2 s$ 6d ferling. F.

$$
0,2
$$




\section{TOREEN'S VOYAGL.}

rupee is valued at forty-eight poife or pice, and a poife at forty-eight almonds. The coiring is performed with an hammer, which is directed by the hand. This is the reafon that the rupees fometimes crack, which makes them found ill in the hand of a banker, and lowers their value. There is a fpecies of rupees which has the honour of being mentioned by ou connoiffeurs in coins: but what I have read. in their books, was different from the account which was given me in the Inaies. If it is right, it is as follows: "Nour Mabal, "the wife of an officer, was once undefignedly "feen by the Great Mogol feban Gbir, who, "fince he could not come at her by any other " means, made away with her hufband, and, "after many folicitations, at laft prevailed" "upon the deeply-afflicted widow to accept "s of his own bed. Her step-children felt " how well this beautiful lady was Ikilled in "politics. Feban Gbir changed her name, " and inftead of Nour Metsal (Light of the $v^{46}$ Ladies), called her Nour Fchan (the Light " of the World, or of Fchan). He likewife " once gave her the liberty of having rupees "s coined under her name; and added that ss compliment to it that the might ftamp the or elve heavenly figas on them." Thefe coins 
coins are already fcarce in Indoftan: and the reafon, as I was told, is, becaufe the Moorifh ladies ufe them for necklaces; which is very probable, confidering the great confidence the $M a$ hometans repore in fafcination, amulets, the influence of the ftars, talifmans, \&c. The rupees are current along all the coaft of $A f i a_{\text {, }}$ but under different values. Thus a Bombay or Pondicherry rupee lofes four per cent. in Suratte; and on the other hand, a Suratte rupee lofes at Mabee. The orders of the magiftrates feem to be infufficient to fettle this difference, for the Banian will give a greater value than perhaps would be fettled by regulation, if from the purenefs of the filver he finds he can be a gainer. We new-comers were not the only ones who fuffered inconvenience from the change of value, but even thofe who had already made a ftay of fome years here were not free from it. But befides this four per cent. you likewife lofe two, three, up to four per cent. according to the fum, if you give money to your fervant to barter it, or buy fomething with it. This he does not take clandeftinely, but looks upon it as his perquifite, which he thinks the buyer or feller mult pay him without making any difliculties.

O 3 There 


\section{I98 TOREEN'S VOYAGE.}

THERE are many forts of animals in this country, but this dry foil cannot fupport them in great numbers. The nabob had a very large and fierce tiger in a cage. In another place I faw a lefs one, marked with ftripes acrofs; but its fnout, gait, and eyes, gave him the appearance of a wolf. If you fleep in a farmer's room at night, it is not uncommon to hear the howling of the jackcall ${ }^{\circ}(\mathrm{Ca}$ nis aurcus Linn.) round the houfe. The nabob had likewife fome elephants in his poffefion, which are only made ufe of when he and his family have a mind to fhew themfelves on fome feftival. During our fay we faw the gratitude of an elephant: a foldier in the Dutch fervice ufed to go into the governor's ftables, and to feed an old elephant with the rice which he had about him; he once came fo drunk to him that he tumbled down under the animal, and fell alleep between its feet; but the elephant guarded him fo carefully, that fcarce a fly dared to come near him.

Horses are very rare and valuable animals in Indoftan. The beft horfes are brought

For jackcall fre Hafelquifis's Travels.

oves 


\section{SURATTE. 1750.}

over fea from Arabia, where the Arabians fometimes efteem them above their wives and children I have been told, that fometimes they pay as much for the genealogy of a horfe as for the horfe itrelf.

WE did not fee many camels. The goats are of that kind which have pendent ears. The oxen have a hump on the back like thofe at Madagafcar, Joanna, and as far as the Straits of Malacca. The theep have bent fnouts and pendent ears, their wool is more coarfe and ftiff than the goats hair, which plainly convinced me that a warm climate does not always produce fine and foft wool. Higher up in the country Gazells are to be met with: you muft already have feen, Sir, that their horns have rings all the way, and are fcrew-thaped, by the offenfive and defenfive arms which I bought of a Patan, and which M. Lagerftrom undoubiedly hath fent you before this time.

Sone Germanis cail the turkeys? Calcutta hens; for this reafon I looked about for then? here, and only found them in one place, and

(3. Turkies are aitogether American.

O 4 
200 TOREEN'S VOYAGE.

to the beft of my remembrance I was told that they were foreign in this country:

GREEN parrots with long tails (Pfittacus articularius) are very numerous here. Their fagacity in knowing where to find a breakfaft is remarkable: for the houfe of the Shafdaar Khan was built in fuch a manner, that through forme holes contrived for that purpofe the birds could get to the rice which was refufed to the pöor inhabitants.

THEY put oxen before their waggons and carts, and take as much care of them as a hackney-coachman of his horfes. Their excrements are gathered, mixed with ftraw, and ufed as fuel ; the arhes of it make the paint which the Bramins ufe. They want no whip to drive them, but in the Portugueze. manner a ftick with a fpike at its end. Their carts are of a peculiar conftruction: the axle. tree is made of iron, and farcely of the thicknefs of the laft joint of the little finger; it is faftened to the axle-tree of the wheels: the wheel moves between an upright ftanding pole and two linch-pins, which, together with an arch, carry the bamboo net or cover on which one fits; this is either with or without curtains, 


\section{SURATTE. 1750. 201}

curtains. The bamboo fticks bend upwards sear the thill, and make a feat for the driver, on which he rides as on a faddle. This is the carriage of the common people. The Armenians and Europeans rode in coaches, but they were of fuch a conftruction as I fuppofe might have been in fafhion in the year 1500 .

ThE greater nobility are carried in a palekee, which looks very like a hammock faftened to a crooked pole. When the ladies are carried, they are thut up in a box twifted of bamboo, which is afterwards covered at the top with double cloths. On each fide goes a ftout black eunuch, with a drawn fabre in his hand.

Thovgr dogs are held in abomination by the Mabometans, yet the ftreets are full of them. The Perfees have a certain veneration for them; and I was told, that in a famine which happened fome years ago, alms were given to the dogs.

The houfes are not fo infefted with lizards here as in other parts of Eaft India; but even the ftone walls in the uppermoft ftories are not free from a fort of little brownants. The Gentoos take 


\section{TOREEN'S VOYAGE.}

take great care not to kill any one, and feed them with powder fugar, which they throw on the floor.

I was told, that the heat was fill greater at Gamron and Baffora than at Suratte: and if this is true, then it muft be exceflive; and I do not wonder that the Dutch have given up Gamron. Even in October the Szeredifh thermometer rofe thirty-feven degrees. A Florentine thermometer was at half an hour palt five o'clock in the morning at thirty-feven degrees, and in the afternoon it rofe to feventyfive degrees. Father Bonaventura has obferved that the cold is greater three days before and three days after the new moon. It is fomewhat fingular, that notwithfanding this place is but juft north of the xquator, the time between the months of May and September fhould be called winter, and other months fummer, only becaufe it rains during the former.

Tine Chriftians in Suratic are Armenians, of which the greateft part were natives of $\mathcal{F u l f a}$, and have their Aicbimandrite here. They have feveral books in their language, printed at Anfordam. They are known in trade on 


\section{S URATTE. I 750. 203}

account of their induftry and cunning, and live very well on their profits. It is here neceffary that a merchant fhould cut a great figure, fome of them drefs quite in the Moorifs faftion, and wear a turban; others a callot and a velvet cap, with four prominent parts; the brim is two inches high, open behind and before. They have commonly their throud from the fepulchre of CHRIST ready at kand $q$.

The Portugueze are the only Roman catholics who live here. It is remarkable, however, that, notwithftanding the feverity of the Portuguezo inquifition againft the $\mathcal{F}$ eros, the Fere Fioben has the management of the Portugueze affairs at Suratte.

The Frencí feem to endeavour to re-eftablifh their declining trade. Three Frencb capuchin friars hired a houfe, and were forced to get their bread as well as they could. Their fuperior father Bonaventura fometimes gained fome fmall benefactions to the convent by his knowledge of medicine, though he was obliged to give many plafters away gratis.

a A confecrated hairt perhaps from the fepulchre at FeruSolcms.

There 


\section{TOREEN'S VOYAGE.}

Thefe preachers of the gofpel are obliged, by the commands of their defpotic fuperiors, to continue here during their whole lifeton

THE Dutch have a director, with a council and officers, as is ufual with them in Eafe India.

THE chief factory of the Englifh in there parts is Bombay; however, they have likewife a factory at Suratte, with the neceffary officers. All the factories belonging to the Englifh in the Eaft Indies have chaplains.

HERE are likewife fews poffefled of confiderable wealth. One, by name Mofes Tobias, vwas diftinguyifned on account of his liberality tovrards people of all religions: he is faid to bave commonly diftributed in charity forty rupees per month. A cakan, or fcribe, told us, that the long-fought-for fceptre of fuda could ftill be found; and that he had certain accounts of a great number of Ferws in Afri$c a$, to the weft of Aby/finia, who ftill were fubject to their own magiftrates.

THERE is an admiral at Suratte, but he has se misfortupe of having no hips under his command. 
command. The Englifh and the Dutch exercife the privileges of admiralty in the harbour, fo that aot a ingle floop can get up to the town without their permision. Their greateft merchant fhips are built after the European manner. It is remarkable, that the older a hip is, the eafier it procures a cargoe, becaufe it is thought to be lucky. The fhips which they make ufe of againft their enemies are called goerabbs by the Dutch, and grabbs by the Englifh, have two or three mafts, and are built like our hips, with the fame fort of rigging, only their prows are low and tharp as in gallies, that they may not only place fome cannons in them, but likewife, in cafe of emergency, fix a couple of oars, to pufh the grabb on in a calm. Gallivates are lef3, and are ufed, like the grabbs, in piracies and for trade. They have feldom more than one maft, and incline forwards fixteen or eighteen degrees: they have a fail, which at a certain diftance looks triangular, though it has four corners. The boats which are called burry have the fame fails. 'The fhip floops, which are worked on with faddles, are like the preceding, fomewhat pointed before, and narrow behind. The planks of all thefe veffels are made fo oblique, that they lie one above an- 


\section{TOREEN'S VOYAGE.}

other; they are fantened with rails. Infead. of tow and tar, they uie cotton and a fort of thick oil, which is faid to make them fo tight that they have lets occafion to ufe the pump than the Europacans. In the timber which they ufe to build thips of, iron does not ruft fo much as in oak; for which reafon they are forced to clench the nails well on the infide, and therefore our thort thick nails are of no ufe.

THis nation has a peculiar agility in fwimming; I faw one fwim a good way, and hold above water eight pound weight in his hand. Practice does much towards this feat; but perhaps there is a light in it, for they only make ufe of the right arm and left foot, and then the left arm and right foot alternately. During the time of our ftay here we were not attacked by pirates. On the 20 th of October a pirate, who was called Budgero, anchored in the harbour accompanied by about two hundred great and fmall veffels, which made a good appearance at a diftance; on their approaching and anchoring in part between us and the fhore, we prepared every thing in order to receive them. However, they did not offer us the leaft infult, but after a day or two went their

way 


\section{SURATTE. 1750. 207}

way and left us alone. Yet it muft not be fuppofed that they are always fo civil. In Sep-, tember fome Gallivates failed out of the port, having an Englifh thip for their conroy. Is was attacked before our eyes, and in the face of the other Englifh fhips, by eight or nine piratical Gallivates which kept up a continual fire for a couple of hours, without any body being able to give affiftance, on account of the tide. The end of this was, that the pirates fucceeded in taking two or three of the other Gallivates; upon which they left the Englifh fhip to purfue her voyage without any farthe: moleftation.

I AM unwilling to omit one or two accounts belonging to political intelligence, though $I$ cannot be anfwerable for their truth. Towards the end of April, 1748 , died the great Mogol Mabomed, of the venereal difeafe according to the Jefuit Tiefentbaler's account. His only fon Acbmed, by a concubine, fucceeded him, and was then on his march returning from Seranda, where he had defeated the army of the Patans, who had undertaken an irruption into the empire from the mountains of: Kandabar. Of the fate of the Perfian em. pire, I had the following account. Nadir

Shats 
208 TOREEN'S VOYAGE.

Shab put out his eldeft fon's eyes, from fufpicion, and appointed his other fon his fucceffor. But after Nadir Shab was murdered on a hunting match, all his family were killed by his nephew called Adel Shab, only excepting Sha Rock Shab , who was Nadir Shab's grandfon, and the fon of the daughter of Shab Houfain. This Adel Shab is faid to have been very mild towards his fubjects, efpecially towards thofe who lived about Ifpaban; for he not only freed them from paying any thing to the king for five years, but alfo gave them money to enable them to cultivate the foil. When he was vifited by the law of retaliation, Sha Rock Shab took poffeffion of Kharazan, and had, as I was told, the greatert part of the riches of Nadir Sbab in his hands: Solyman Shab, who was formerly Sba Rock's fervant, took poffeftion of IJpaban, and Cely Nebemet Shab took Tauris; the undertaking of prince Heraclius we firt learnt at Canton, where the Armenians told it with great expreffions of joy。

WE weighed anchor the if of March, 175 I, after a flay of five months and a half;

- Mr. Toreen feems to be miftaken here, fince there is a repetition of the word Shab in Sba Rock Sha. F. 


\section{IN A N GULOR: 175\%: 209}

during all which time I had no opportunity of being on thore more than twenty-three days. We failed to Mangulor with land and fea winds, fucceflively changing, and anchored there the inth of the fame month, with the fame difficulty as at Suratte. After this, we dil not anchor before we came to Canton. It would be but a fmall experice to make a good and convenient haven, behind a narrow inlet which would contain a whole fleet:

ThE town of Mangulor is open and large; and contains many gardens. The houfes are low, and generally made of a reddith tophaceous ftone, which; as I was told, is foft under ground and eafily worked, but grows hard in the air.

Tye tiles are fhaped as thofe at Suratte and Cadiz. The brickmaker forms a hollow cylinder about twelve inches long, and four in diameter; this is cut into two equal parts lengthways, and burnt in little kilns. They tile here by fingle rows, and when one row of tiles is laid fo that the concave part comes uppermoft, the next is inverted, and fo covers the ridges. There is a conftant faltnefs in the Vol. II: 
earth, both here and in Suratte, which eats away the lime near the ground.

I sAw two waggons, which feemed to be intended to be carried about in a religious proceffion, beficies a reprefentation of a white elephant, which was placed on wheels, as I fuppofe for the fame purpofe. The wheels of the waggon were of one piece of wood, three feet in diameter, and of a proportionable thicknefs; thus they are more than fufficient to crufh the poor people who expect to gain eternal happinefs under the facred wheels.

THE inhabitants are heathens: they drefs like thofe at Suratte, except that the cottons with red fripes are more in ufe here, and that they go barefooted, or bind a wooden fole under their feet like the friars of the order of St. Francis. When they ride on horfeback, they only put their great toes into the ftirrups.

Banian trees. (Ficus Indica) are very numerous and large: they are taken great care of. Pound about this place are great and open woods; but I was told, that if I entered 
them I hould be loft, becaufe they were the habitations of many fierce tigers.

I COULD only be twelve hours on fhore. The 17 th of March we left this place, and having nothing to do at Cananor, we fuiled to Mabie, where we ftopped the Igth of the fame inonth.

THIs town or plantation belongs to the French E. I. company. It is near the fhore; and the mouth of the river is fo covered with a ridge of rocks above the water, that a franger cannot get up with a boat. Several redoubts with high ramparts ferve as a defence, which in this country are efteemed a confiderable fortification. At the top of one of the redoubts, blocks of wood were erested, which at a diftance looked like men. I forgot to enquire into their ufe, but they feemed to me very proper to fill the holes when the garrifon was forced to be on the ramparts. This would be an invention, which in fome cafes might be as ufeful as blocks of rood inttead of cannons. I have often heard that wooden heads are placed in the advanced ftations; but that they are likewife ufed as blind works in freges, I never knew yet. 
$2: 2$ TOREEN'S VOYAGE.

Tife fun was exactly vertical to us; the thunder was heard to make an exceeding great noife, efpecially on the Cardomom mountain: the heat was fo intolerable, that even the natives were forced to keep in during the middle of the day. The poifon of fnakes and of other venomous animals feems to be more fatal in hot climates than in cold; if the accounts we have in Sweden of the viper's bite, and in Eaft India of the fcorpion's fting, are true. The French therefore quite diffuaded me from going into the woods. Nor could I have made any ufeful obfervations there; for the perfon that undertakes to amend and explain the Hortus Malabaricus ought to be mafter of the Portugueze and Malabaric names, which Baron Rbede has confounded; and the time of one's ftay here ought to be the whole rainy feafon; becaufe at other times the burntup Malabaric foil is unable to produce either flowers or fruits; but this feafon is very dangerous for thips on account of the hurricanes.

It is impoffible to examine a plant in fuch a fcorching heat, without one knows all its characteriftics as it were by heart: for while you hold it between the fingers for a moment 
or two, it withers and becomes unfit for prefervation. I learnt this on my former voyage by very irkfome experience: and therefore, when I could not get feveral fpecimens of the fame plant, it feemed beft to me to keep fingle ones for our mafter. I here faw the thick bamboo in one place. Its height was fcarce four fathoms, its ftem, which is the thicknefs of a hand's breadth, is naked, and has only fome digitated leaves at the rop. Its numerous ears, which came out of their fpathas on the middle of the ftem, were then in bud. The other fpecies of bamboo, grow to the height of fix or feven fathoms, but they are not above an inch thick. They have branches on the ftem, and thofe have again pinnated leaves.

I HAD here an opportunity of admiring an elephant. Its mafter had let it for a certain fum per day; its employment was to carry timber for building, out of the river, which bufinefs it difpatched very handily under the command of a boy, and afterwards laid each piece one upon another in fuch good order, that no man could have done it better. 
214 TOREEN'S VOYAGE.

If all the Malabaric oxen are like thofe which we got, I do not wonder, that thofe heathens will not eat their fleth. The mere defcription of them would make the moft hungry lofe their appetites. If we muft derive the badnefs of their flefl from the oejirus s, then either the caufe or the effect is greater here than in Sruedcn. Perhaps this dainty meat was the occafion, or at leaft contributed to the following difeafe: viz. that many of our men were afterward exceedingly tormented by intolerable bloody ulcers.

Tru uglieft animals we faw were the Gentoo women, who were quite naked except their thighs. Their naked and jetty bodies were not in the leaft alluring.

In Mabie I obtained that curious infect, which has a long finew between the thoras and body, and is in the little collection which I have fent you.

s The effrus bovis depofits its eggs in the backs of cows, which turn to maggots as large as the end of one's finger, called in fome counties of England, wornils. When catile are peftered with thefo, they are always out of condition. See Derbam's Pbyfico Tbscl.

THOUGH 
Though I am not difpored to judge of the European nations, merely by their behaviour towards each other in the Eaft Indies; yet I cannot omit taking notice, that the French have every where been very civil to us. They always called us leurs grands alliés, that is, their great allies; and their civility extended fo far as to give us leave to bury one of our dead in their church at Mlabic.

Our fuperiors had made no regulations on fhore ; for which reafon, every one who went on fhore was forced to procure as he could every thing for himfelf; which made it more advantageous to fay on board.

Besides the gold coin, called pagoda, which is valued at four rupees, their filver coins are rupees of which each contains five fanno. Tar is a copper coin of different values.

THE boats, which are made ufe of here and at Mangulor, have flat bortoms, like common boats, and are pointed at both ends. For fear of overfetting, one ought to know how to keep an exact equilibrium. I was told that the Malabaric rowers at Mabie were obliged

$$
\mathrm{P}_{4}
$$


to give head for head, if an European wa drowned in their boats.

AFter we had provided ourfelves with the aforementioned animals, which were only like oxen, and with other things, we fet fail the $21 \mathrm{ft}$ of April. Nothing particular happened, except our lofing the main yard, and another - yard. This damage was eafily repaired; but we loft four fuip boys ou this occafion. Afterwards our voyage to $2 u d d a$, in the fraits of Alalacca, was very fortunate; and we caft anchor there the $13^{\text {th }}$ of May.

The country is very low to a great dift: ance from the fea fhore, and every where covered with thick forefts. Among the trees was the tamarind tree; the papay tree; the Abrus precatorius (the feeds of which the inhabitants of the Malacca coaft put into rings for want of ftones, becaufe it is not ufual among the eaftern nations to wear mere gold rings); a tree, which I could not get to, but obferved that it fent branches towards the earth from the top, different from its common branches. The Engli $乃$ call it mangroves in the Weft Indies. 
AN unfinithed caftle was fituated on the mouth of a fmooth river. The engineer feemed to be no difciple of Vrauban. The faces were parallel to the curtains, and the walls fo thin that half a dozen fix pounders would have made a breach. In the infide were fome houfes, the roofs of which ferved for batteries. The cannons were moit of them from an $E n g-$ lifh hip which was loft juft before the river, but fo leifurely that there was even time to get thofe heavy goods out. Though this caftle has fuch a miferable appearance in the eyes of Europeans; yet it is fufficient to keep the nations hereabouts in awe, merely becaufe it looks European. I faw here fome prifoners, whofe necks and hands were faftened to a pole with willow-twigs. They had coined money, and feemed not to hope for pardon: but did by no means thew any fear; a foolith infenfibility muft be the effect of the doctrine of unavoidable deftiny.

TuE other houfes are generally built on poles, four feet above ground, on account of the high tide. The walls and floors are freguently made of bamboo fticks fplit in pieces.

Mahмu D 
:18 TOREEN'S VOYAGE.

Miamud Houfain $\mathrm{Ba} h a$, who was mafter of the place, was a vaffal to the king of Siam. He was exceedingly interefted for the promotion of trade in his countiy. He was (as all the other Malayans) a Mobammedan; but tolerated heathens and Chriftians. He would not permit the widow of a Frenchman to go away; but made up matters fo well, that the married a Chinefe Chriftian, in order to have the Europeans who come there well received, for he wanted to ingratiate himfelf with them. We could not take in the quantity of tin that we intended, as he infifted on keeping fome for the fhips that were coming after us.

OXEN, buffaloes, and chicken, are very reafonable. The woods are the habitations of tigers, which are faid not to attack men: but as they carry off the dogs from the houfes, one dares not venture out far. Monkeys are very numerous; fome are large, with very long tails, grey hairs, white beards, and black fkin; fome lefs ones have thort tails bending upwards. A parrot (Pfittacus galgulus) was no bigger than a goldfinch. Its colour was dark green on the back, and light green un- 


\section{QUE D A. $175 \mathrm{I}$.}

der the belly: the upper fide of the tail and the throat were red; the bill was black. Some had a blue fpot on the head. When they fleep, they always hang in the cage fo as to point with their head downwards. We obferved that their nefts were remarkable for their exceeding fine texture; but we did not fee the birds. If they had a different conftruction, the monkeys would be very mifchievous to them; but now, before they can get to the opening, the loweft part as the weakert breaks in pieces, and the vifitor falls to the ground without any danger to the young birds.

THERE are feveral forts of crabs in the fea, befides various other fines. I thould be forry if one-fpecies which I fent you by Mr. Lagerfrom thould be injured; its eyes were on long pedunculi, and it had peculiar feet (Cancer arenarius). While it was alive, its eyes fparkled in the dark, like cat's eyes. In and by the ficle of the river are whole cart-lozts of oyfters, and likewife crocodiles by hundreds. When the water during the tide fills all the ponds and ditches, with which nature has divided this low country, the crocodiles go up a good way 
into the woods; therefore, when a great motion is heard in thefe pools of water, the beft way is to make off immediately.

TIN is not found in this Baflawes country, that I know of: but he has the toll and cuftom of what is brought there. I am told, that in the places where it comes from, they do not fetch it out of the mountains, but dig it out of the ground, together with the fand. It is reckoned better than Englifh tin, at leaft a Chinefe likes it better.

$T_{\mathrm{HE}}$ coins are rupees. A rupee contains three cupang, and a cupang four condorin. They are all filver.

THE $27_{\text {th }}$ of May we fet fail : before $S a$ lingor we ftaid in vain from the 3oth of Miay to the $2 \mathrm{~d}$ of func: but afterwards we failed among the many fine illands in the Straits of Sonda. On one of thefe iflands is a fpecies of ftones very like the fand-ftone from Oland, but it burft into little cubic pieces, fcarce above one foot and a half long, and as much broad. 


\section{MAC A O. I75I. 22I}

IN the beginning of July we firft faw Cbina. We paffed Macao, were fearched by the cuftom-houfe officers, who are in the caftle near the narrow mouth called Bocca Tigris, and anchored nearWampoo the 7th of July. 


\section{$\begin{array}{lllllll}L & E & T & T & E & R & V\end{array}$}

"HE I th of March I fent the continua: I tion of my accounts by a friend. I will now relate what $I$ have feen in China.

A PERSON who for the firft time vifits this country, thinks he has a new world before him; for almoft every thing looks different from what he has feen in other places, unlefs where climate renders fome fimularity of cuf: toms neceffary.

THE rocks and the fhore, even a good way into the fea, are covered with finhermen and their tackle; which fight immediately leads one to conclude, that the country muft be very populous. The naked and unimhabited inlands hereabouts feem at firf to occafion other thoughts; but, on advancing a little further, the plains and vallies fpeak the number and the induftry of the inhabitants.

THE loweft fields are fowed with rice, becaufe it requires a great deal of water, which it 
it gets by the tide without any trouble to the hufbandman. Thefe fields are croffed by fuch great canals, that during the flood one may go in boats on them. Rice is fowed and reaped twice a year. During its growth, it is pulled out and planted into ferpentine lines, to admit the water more freely to the roots. Thofe who have not the advantage of the tide, are forced to carry or lead the water, or bring it up by machines, of which Mr. William Chambers made a drawing on a former voyage, and has probably communicated it to the fuperintendant Baron Horlemainn.

THE high places are likervife employed to great advantage: for there are mountains whofe declivity amounts even to forty degrees; but they are divided into feveral terraces, on which are planted Conrolvuluis Batatas t, Diofcorea ", Go/ypium ", fugar-canes, and many other plants, according to the time of the year, or quality of the foil. When it rains, the rain water is preferved, and conveyed from one ftory to another. If it rains too much, a ditch is opened, through which the water may run away freely. The ufe of dung may be judg-

Spanifh potatoes.

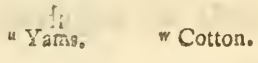


ed of by the careful manner of gathering of it at Canton, and by the ftinking fampanes, or boats, which daily pafs by our thips. But on the fields which were near the fhips, we feldom faw any other manure than the roots of rice, which, together with the clay fticking to them, are thrown on the higher foil, which is mixed with fpar.

Those places which cannot be tilled, are planted with trees, if the high fituation and dry foil will allow of it. But a great part of fuch places are deftined for burying-grounds; which practice would induce one at firft to fuppofe that the Chinefe acted againft their own principles, in leaving fo much ground for burying-places, and by that means making them unfir for ufe; fince the graves muft not be difturbed. But for this very reafon moft people are buried on fteep mountains, or other places which cannot be ufed for other purpofes. The refpect which children and pofterity fhew to their parents and anceltors, even after death, is to be confidered as a confequence of the implicit obedience to which they are obliged in their life time; and which is the foundation of their exceeding great fubmiffion towards the magiftrates, without which it ivould 


\section{H I N $A .175$ I.}

would be impoffible to rul s fuch a number of unmannerly, ftubborn fubjects. Over their graves are generally little open ftone-buildings, which are almoft femicircular, and have a niche for a perfuming veffel. I only found onle fingle grave more magnificent than the reft, on the northern fide of the town; it was covered by two round vaults, and lhut up by a wall.

ON fome high hills there are towers. They have all of them eight fides, are nine ftories high, are almoft every where of equal breadth within, have every where windows, and terminating in a point. I was told, that in time of war they were ufed as watch towers: they are therefore fo difperfed, that the given fignals can eafily be feen from one tower to another. In the villages were lefs fquare towers, three ftories high; but the Chinefe faid, that they were pagodas.

ONE of the firft things on arriving here is to procure a banc/hall; this is, a great houfe conftructed of bamboo and mats on a place appointed for that purpofe, in which the ftores of the fhip are laid up, and whatever is not abfolutely neceffary on-board, or whatever VOL. II. 
226 TOREEN'S VOYACE.

would be in the way during the cleanfing; lading, and clearing of the fhip. The Dutch fay, that they will fpend no money in building a banchal; but others fay, that the Chinefe will not give them leave. Thofe who have been confined to a fhip fo long as we had been, would eafily be attracted by the adjacent ines to go on thore. The French ifiand, where the French have their banchals, is almoft the only one where we enjoy the liberty of burying our dead. It is dangerous for a fingle perfon to venture too far, becaufe he is in danger of being ftripped to the very fhirt. Though the curiofity of the Europeans may not be perhaps roid of blame; yet the natives look as if they were glad to find a pretence to ufe violence againft a ftranger, efpecially when they are fure of over-powering him.

$\mathrm{O}_{\mathrm{N}}$ the paffage from the place where the thips ride at anchor to Canton, which is one Swedift mile and a haif, you are obliged to have your baggage vifited three or four times. The cuftom-houfe officer, who lies in his boat continually, quite clofe to the fhip, gives an inventory of every thing you take with you; and all that you carry befides is to be confifcated according to the laws at the three cuftomhoufes, 


\section{II I N A. I 75 I.}

houfes, where you are obliged to ftop; except you go in a floop with a flag. The river is at firt on both fides bordered with rice-fields: and this is the fatal focne on which many lafo civious Europeans have loft their health.

THE further ycu advance up the river, the more the number of both great and fmall veffels increafed, part of which lie ftill, and part go up and down the river. Nearer to the town they have fcarce room upon the river; but are forced to bear hard one againft another behind and before; and to form, as it were, ftreets, length-ways and crofs-ways. Thofe who in this manner fpend their time on the water, are not all of them railors or fifhermen: the ferrymen, who come and fet off at certain times, are in great numbers; but the rowers, or oar-men, are ftill more numerous. The others are tradefmen, fuch as carry on rome fort of bufinels; they keep wives and children, hogs, and chicken, together with all their utenfils, in thefe boats; for which reafon they need not come on fhore: aiid there are particular people appointed by the government to overlook them. I can fay no more of the city of Canton itfelf, than that its drawing in Lord Anfon's Voyage round the

$$
\mathrm{Q}_{2} \text { worlt }
$$


world is inaccurate, and taken from an old drawing which I had already feen in Sweden before Lord Anfon left England; and the original itfelf is very faulty. It is furrounded by a fmooth, round, high rampart, which has at the top loop-holes, or crenaux, very clofe together. In the river are three little inlands, with caftles in the fame manner; with this addition, that in the infide a cavalier two ftories high is raifed, which commands the works within and without, and likewife ferves as a retirade. The other redoubts on the neighbouring hills on the country fide are of fuch a conftruction, as thews that the plan is defigned for fecurity, but not to thew their genius for war. A work like this might be defended for a long while in this country by good officers and valiant foldiers : but when a Chinefe knows there is a place of retreat, he would hardly dare to perform heroic atchievements on the out-works.

THE fuburbs, in which the Europeans have their factories, are divided by many canals, and crowded with buildings as full as poffible; for feveral of the houfes are even a great way over the water, built on piles. The lodgings are fpacious, and the yards narrow and long, 


\section{H I N A. 1751 .}

and therefore they have been obliged to make fhift as they can. Since they like to lead their foughs underground, the foundations of their houfes muft coft a great deal ; but the fuperftructures are not very durable. Here and there you meet with open yards, in the midnt of which the floors of lodging-rooms are laid, and covered with nothing elfe but a tile-roof. The ftairs are under the fame inconvenience with thofe at Suratte, viz. they are narrow, and the fteps are high and likewife narrow. When the rooms cannot get light enough from the doors and open walls, they have windows of mother-of-pearl: for which reafon the cathedral church at Goa, on account of fuch windows, need not be thought one of the wonders of the world. The walls are covered with fine white or painted paper, and ornamented with fome Chinese or European drawings. The Chinese in their own houfes fix up generally fome tables of proverbs. Almoft clofe to each room is a little garden, in which are fome flower-beds, and fcaffolds for fowerpots, and greater veffels for thells, goldfilhes, \&c.

Their pillars or columns ferve only to bear she rafters. Mr. Chambers, I fuppofe, has al-

$$
\text { Q3 }
$$
ready 
ready given us the proportion of the parts, To judge by the appearance of a triumpha? arch, the width of the middlemoft portico feemed to be twa thirds of the whole height: the fide porticos were in the fame proportion to the middlemoft, with regard to height and breadth. The populace hindered me from taking a more exact menfure.

You find no trees trained up by art, nor walks, nor flower-pieces of feveral figures, in a Chirefe garden; bur every thing is in an agreable natural confufion. Inftead of grottoes they throw a heap of a porous fort of flones togẹther, which look like rocks and mountains. This tafte of the romantic in gardens extends even to the imall flower-bects, and flower-pots in houfes.

One of the principal pagrodas is in a fine wood in the fuburbs; on the outfide it is like the others, but it is higher and more fpacious, I was told, that it formerly belonged to the jefuits. The ftructure and ftories are entirely according to a correct Cbinefe tafte. In the loweft divifion, or in the hall, were four gigantic ftatucs, one of a white, one of a brown, one of a black, and one of a red colours 


\section{II I N A. 175 I.}

colour, in the attitude of flourifhing about them with their fwords: this has no Clbinefe appearance; for, even fuppofing they knew the complexion of the Americans (of which, however, I greatly doubt), they would moft probably be of opinion that the honour of attending upon the gods belonged to themfelves alone, exclufive of all others. Thefe ftatues have likewife wider eyes than are to be met with among the Cbinefe. Perhaps they were intended to thew the univerfality of the church of Rome, about which they give themfelves more trouble than about all its other qualities. In the back-parts is a court furrounded with low buildings; before it ftands an high, open, large houfe, which is broader than long, as is ufual in pagodas. Steps furround the whole building, as is ufual in the South of Europe. Nobody is allowed to pafs through the door, for reafons unknown: therefore I decline advancing any uncertain furmifes concerning the idols, which could hardly be difcerned in fo dark a room. On advancing fometwhat further, you again come to a yard, which is divided by a canal, and has likewife a pasoda of two ftories high on the other fide. In the lower ftory a fquat, fat, half-naked idol, is feated upon an altar or fofa; it feems to be

$$
\text { Q4 breaking }
$$


232 TOREEN'S VOYAGE.

breaking out into an horfe laugh; and is fitting on one leg, and holding up the other knee: in fhort, it is in a very indecent pofture, Before it ftands an iron perfuming vafe, on which matches made of wood-hhavings are burning. In the upper itory is a female figure, fitting with her legs acrofs, and fmiling very decently with downcaft eyes. Both ftasues are of a gigantic fize, and gilt all over. Out of town, in the outward apartments of a pagoda fituated on a hill, are two white equeftrian ftatues. In the moft outward room is a little ftatue reprefenting a woman with a child in her arms; in the inner room is a larger idol on a chair, which, after the Chinefe fathion, has a long beard; and before it are four other ftatues. In cach houfe, and aboard all fhips and fampanes, is a little chapel on the larboard fide, in which they burn incenfe, or put orange-trëes, Exc. Sometimes the whole chapel confits of painted, fometimes of torn, paper, and a veffel with ahes and matches.

THE failors, and even fome books of voyages (as may be feen from de Uris's notes), call the pagodas, $Y$ afs-boufes: for, on enquiring of a Cbinefe for the name of the idol, he anfwers, Grande Yofs, inftead of Gran Dios. I have not 


\section{HIN A. 1751 .}

feen the deformed idols of which Pinto fpeaks. The bonzes, who minifter in the pagodas, wear long grey cloaths, reaching down to the feet, with wide fleeves; their heads and beards are fhaved; their caps are black and round. On the other fide the river is a great pagoda, where near 100 bonzes are kept. They have fuch a great field, that they are not only able to fow the neceffary rice and fruits for themfelves, but likewife to keep cattle; which, it is faid, they only feed and bury. They have all the neceffary tradefmen among themfelves, wherefore they do not feem to be troublefome or chargeable to others. Proceflions with idols, mafks, plays, and jugglers tricks, are frequent enough. As for the reft, the Chinese trouble themfelves very little about their gods and pagodas.

THE people differ very much in fize, but are feldom tall. The men have a yellowifh fin; the ladies are fair, but the common women tawny. The bone above the eyes projects very far, and forms a triangle with the chin. Molt of them never quite open their eyes : and I am told, that the cuftom of bearing the children at their backs, with their heads hanging down, occafions as it were a fwelling 
234 TOREEN'S VOYAGE.

fwelling of the eyc-lids; for the orbits are the fame with them as with other people. Their nofes' are fomewhat flat : their lips middling; and their looks, when they liope to gain any thing, as fweet as poffibly can be.

THE children are at firft shaved, that their hair may grow the thicker; afterwards one or three locks are left. The men, as is well known, are obliged to Shave their heads, exa cepring a turt of laair on the crown, which they plait into three traces. Their high value for their locks of hair feems to abate in forne meafure; for at 2uede I faw two Cbinefe, who, living there, and having laid afide all thoughts of feeing Cbina again, had fhaved their hcads': whereas their neighbour, who was likewife a Cbinefe, had all his hair tied in the old fafhion. Their beards do not grow weill; but perhaps they chufe to have a thin beard. If a Chine fe is aiked what fum would induce him to part with his tuft of hair? he again afis, what you would take for your head? And no wonder that they are fo very careful of an ornament which they have perhaps nourifhed for twenty, thirty, or more years together. The women tie their hair abore the top of the head; and to make the 


\section{H I N A. 1751 .}

tuft of a confiderable thicknefs, they faften rome falfe $h$ ir to it, and ftick as many and as coftly pins or bodkins in it as their circumftances will allow of. They take a great deal of pains to have imooth and gloffy hair; but this is perhaps the reafon why their hair wears off and becomes thin, and ftraggling when they grow old. Both fexes let their nails grow as long as poffille, if they do not interfere with their bufinels.

You fee many blind men $x$ in the freets; and they are the only beggars which are to be obferved. The alms which the Chinefe give them, confift of a fpoonful of rice. The moft common difeafe here is that which naturally proceeds fiom promifcuous luft. A grave Chinefe afferted that they cure this difeafe in a hundred days, por $\tau$ sкvopayiay aliernis diebus, alternis jejumio. I cannot be antwerable for the truth of this account; but fo much I know, thit it is poffible to procure a fufficient quantity of this food. A Chinefe would like ketter to take money for his children, than to

$x$ Perhaps the blindne?s of the Chinefe is for the greatett part the eifect of their voluptuous irregularities; there may be alfo other caules. Compare with this Tifot de febir. biliof. p. 187.189 。 


\section{TOREEN'S VOYAGE.}

be obliged to throw them into the water for nothing. I have no reafon to doubt of the fact I hint at ; fince I have feen feveral children floating on the water: but I cannot pretend to fay whether they are deftroyed with or without the permiffion of the magiftrate.

THEIR cloaths are wide and long, generally confifing of gawze or other thin nuffs. Their boois are embroidered, and made of a fpecies of filk, have thick foles and no heels. Their head is covered with a hat plaited of canes and lined with tiffany; the hat is cone-thaped or like a cover of a difh. On the top of it is a tuft of red filk, which covers the hat on all fides; and on the tuft is a button, by which is diftinguifhed the quality of the wearer, as father Du Halde mentions. In winter they wear round caps of black velvet or fattin, with a Ihallow brim, on which is a tuft of red filk threads: they likewife wear warmer cloaths, The common people wear coarier ftuffs, ftockings of nankin, thoes without buckles of the fame ftuff, and go generally bareheaded. The. pooreft of all wear only breeches. The women go bare-headed; their cloaths fit fomewhat clofer to the body, but ftays are unknown among them. An Engliflaman had his 
wife with him at Canton this year: but the Chinefe could find no proportion between her fpacious hoop-petticoat and her waif. Their thoes are pointed; and have high heels, on which they go crippling as upon ftilts; becaufe the unnatural pofition of the foot takes off all the ftrength and ufe of the toes. The poor only wear a fhort petticoat over their breeches.

THE whole world knows how difficult a matter it is to learn the Cbinefe language; but you can have no true idea of it, till you hear it fpoken yourfelf. Their various accents occafion the great difficulty. They pronounce one word as if they were quarrelling, and prolong the next as if their tongue was fixed to their gums. Their ftrong afpirations, even before the initial confonants, cannot be pronounced by every tongue. The European languages are not very difficult to the Cbinese, if only the $\mathrm{D}$ and $\mathrm{R}$ could be rejected. For they fay inftead of doctor and padri, locta and pali. They can in fore meafure avail themfelves of the $D$, but as to the $R$ it is too diffcult for them. They generally converfe with the Swedes in broken Englifo; and fometimes in broken Portugueze, French, and Dutch: and fome 
$23^{8}$ TOREEN'S VOYAGE.

fome of them fpeak a few words of Swedifis A Cbincfo merchant being afked whether he had any ftockings? Anfwered, no babb. A perfon pointed to a pair of ftockings and faid what is that? Oh, faid he, telumbo, tchumbo. When he is to fay great or fmall, he fays grande or galande, and pequenini; and fo in otler inftances.

OF their genius and character, others have given accounts. I can but wonder that the miftionaries, when they fpeak of their reigning viccs, fuch as avarice, voracioufnefs, great and petty thefts, fliould mention nothing of their beafly luft. It is incredible to fuppofe. them not to have known any thing about it. Though the Cbinefe are too cautious to boait of their irregularities, like fome Europeans, yet, if you liave refided fome time at Canton, you will underftand the Latin bard, who imagined that he tafted the waters of Aganippe, while he was drinking fomething which fhould not be named. Some perhaps may think that fuch fins are looked upon by the mifionaries as peccadillos or little offences, which are of fmall account; but that would be judging too hardly of the reverend fathers. Without doubt, they did not chufe to difcredit the na- 


\section{HINA. 175\% 239}

aion, and mention fuch difadvantageous circumftances. But be this as it will, yet we cannot attribute this vice to the climate, as we might have been rafhly led to do: for the whole argument falls to nothing, when it is feen that the Perfees, which are patterns of chaftity at Suratte, are in the fame climate with the Moors, and have a warmer air than the Italians.

THEY are courageous only when they are fet on ftealing; for then they venture their backs, and even their lives. They are, however, revengeful and malicious, like all narrow minded people. You look in vain among the greateft part of them for difinterefted gratitude, pity, placability, and a generous manner of thinking. Had Rochefoucault been born and bred among the Chine $\int$, he would probably have denied the exiftence of virtue: yet with all thefe faults they are very civil, and are obliged to be fo, becaufe private ceremonies are the object and bufinefs of one of the moit confiderable colleges of the empire. The following is the manner of faluting among them. They clench their left fif, put the right hand on it, drop it down, bow, and lift it up again. Thofe who have accuftomed themfelves to 
$34^{\circ}$ TOREEN'S VOYAGE.

the more free manners of the Europeans, only clench their fifts, and fay kin, kin. They ufe much ceremony at coming in; and before they fit down, will be entreated to do it feveral times. If you vifit them, they entertain you with tea, comfits, and even with European and Cape wine, adapting every thing to the expectations they have of the traffic you are to carry on with them. You are at liberty to walk about their rooms, but muft not approach their females: for the Cbinefe, like all nations among whom polygamy prevails, are jealous. All that I have faid relates only to merchants and tradefmen. How it is with the noblemen, I know not: for what the common people fay of them is not to be relied on, and travellers are apt to add fomewhat of their own invention. 


\section{H I ì A. 175 t.}

242

\section{E T T E R VI:}

A S I have acquired fome knowledge of boA tany by your kind affiftance, and have heard and read of the merits of Baron Rhieede in this branch of learning, I thould have been inexcufeably negligent if I had paffed over his epitaph in filence. As it was inconverient for me to keep pions, I experienced on this, as on many other occafions, the difficulty of waiting till I could get company: but even thefe would not always ftop, when I met with any thing which according to my judgement appeared remarkable. When I came the fe- cond time to Baron Rbeede's grave, I found the thutters faftened. Therefore I could not copy the whole epitaph $\dot{y}$, but only the principal things, which I fhould have communicated long ago, had I thought they were not known.

I HOPE I fhall be able to fay openly in Swe* den what they make no great fecret of in that country, namely that he had been poifoned: nor is it unlikely; fo: fo great power in the hands of an honeft man muft be very dreadful

y The tranflator does not think the epitaph interefting to an Englifs reader.

VOL. II. 
to fome people. If you were to hear fome anecdotes told in Eaft India of the Dutch manner of governing there, you would by no means be aftonifhed to find that the intereft of the company is but feldom trufted to any but thofe who have given undeniable proofs of the good attachment to their own. One is apt to expeet that the magiftrates will take cognizance of thefe things: but they bring this excellent maxim with them out of their own country, leven on leven laten ${ }^{2}$; which keeps them from making any ftrict enquiries.

With your leave, I now intend to proceed to defcribe our voyage, and add the reft of $m y$ obfervations on the behaviour of the Clbinefe.

THEY are either incapable of, or not ufed to, an habit of intenfe inveftigation. Many Europeans are likewife obliged to confefs with

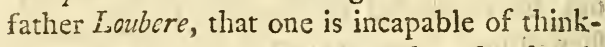
ing much in hot climates. On the other hand, their application to trade is fo much the greater; they purfue gain, without being tired; and as their expectations are frequently boundlefs, fo bankruptcies are frequent among them. All men here traffick; and a To live, and to let others live. 


\section{H I N A $1751 \%$}

when a journeyman comes from his work, he goes about felling trifles, or ftolen goods. They have in cominon with many other nations, the art of cheating in accounts, in mea. fure, weight, and quality of goods; and likewife know how to raife the price of their goods at certain junctures. At the arrival of the fhips from $E m b d e n$, the exchange never fails to alter.

THEx are always ready to fell or to exchange; but they feldom pay away any filver, except for provocatives, of which there is a great fale. It is very peculiar, and one would hardly believe, that they fhould fèt fo great a value on antique paintings, and $P$ orcellane. I once afked a merchant the price of a common tea-pot; which would hardly have coft three dollars of copper money in Sxeeden, but he demanded ten pieces of eight, and Thewed me a ftamp at the bottom of it, according to which, he faid, it was made in the times of fome emperor, who lived four thoufand years ago: as if fuch poor frail veffels had at that time been made ufe of to affit chronology. The occafion of this high price is, probably, besaufe the government efteems antiquities.

R 2 HERE 


\section{TOREEN'S VOYAGE.}

HERE are many artifts who are diligent, and reafonable as to their prices, efpecially if you do not fuffer yourfelves to be cheated, as frequently happens to new comers. Their open fhops have this advantage, that no trade remains a myftery, or is looked upon as difficult by the people paffing by: this, is certainly a great advantage to the inhabitants of the fouth; and might probably take effect in the north, if that cuftom was eftablifhed, that no one muft come into a thop who does not intend to make fome purchafe. I am almoft led to believe that this ftubbornnefs and fufpicion comes from the ufages of the artifts ${ }^{3}$.

THE Cantoncse take great pains to make their goods ftrike the eye, and fell well: but they do not take the fame care to make them good and ftrong; nor do they offer them as the beft and fineft; for when they have a mind to praife their goods, they fay that they come from Nanking, viz. Nanking filk, Nanking ink, Nanking fans, and even Nanking hams.

2 In Siveden and in many northern countries the artifts and tradefinen have often certain filly cuftoms and ceremonies, through which the apprentices inuft pafs, whes they are to be declared journeymen. F.

THEIR 


\section{H I N A. 1751, 245}

Their painters would acquit themfelves very well, if they knew how to thade. You meet with very fine drawings painted on paper and glafs; and likewife the very worft. Japanned wood and enameled copper is feldom to be got elfewhere at the price which it bears here. I have not heard of any carvers in wood or ftone; but images and bufts of clay are cheap.

THE joiners copy almoft every thing that is fhewn them. They have but few tools; and what thould they do with a joiner's-bench, when their foot ferves the fame purpofe? The chief ftrength of their joints is from the glue. Nor do the fmiths undertake any great pieces of work: for when they intend to make rings or buckles, they do not beat them round, but caft the metal.

Both weavers and fuch perfons as prepare filk and cotton are in great numbers. Here are likewife goldfmiths, pewterers, Porcellane painters, and tinkers, together with many others. Thofe perfons who cut peoples nails and corns make ufe of an inftrument, which is like that of a turner.

$$
\mathrm{R}_{3} \text { THEIR }
$$




\section{$=40^{\circ}$ TOREEN'S VOYAGE.}

THEIR barbers have an exceeding light hand at having; but a perfon who is not ufed to their cuftoms, will be aftonifhed when they afterwards pull him by the nofe, and begin to thump his back with their clenched fifts.

THeir phyficians feem, to be very attenrive, becaufe they fpend an hour in feeling the pulfe; but they muft likewife make ufe of quacks tricks, when they pretend to tell by it the number of ftools which the patient has ḩad.

THE dropping and weak cyes of the Cbinese are occafioned by the rice, which is their moft ufual food, as the Europeans fay. Next to rice, their mort ufual diet is bacon and falt finl; both are cut into little bits, and eaten together with the rice: they convey the victuals to their mouths with a couple of fticks. People of higher quality feaft upon birds-nefts ${ }^{b}$, finews of deer, and the like corroborative dainties. Between meals they make ufe of tea, fweetmeats, betle, and tobacco, which is almoft ąs fmall as fnuff, and is fmoaked in brafs tobacco pipes by perfons of both fexes. The Cbinefe,

o See झote, p. 2,5 , vol. I. 
as well as all other eaftern nations, love opium, though it is ftrongly prohibited.

THEY love to play with dice, at a fort of draughts c, and with wooden cards, \&c.; yet the liberty of playing is under fome reftrictions among them. Their jugglers are exceedingly dexterous; one of them produced a piece of wood, and after fome bocus pocus brought a living fnake and a tortoife before us. They act plays in the ftreets, between two of the upper ftories, or in other places where there is room for the fpectators. In the reprefentation of their plays, they run into many grofs abfurdities; fuch as reprefenting two armies by eight or ten perfons, who, inftead of climbing up rocks, get upon chairs, and fo on. However, the companies, which confift merely of little boys, poffefs a wondrous fluency of language; for they often act whole days together without ftopping, making grimaces without end, now finging, now fpeaking, and all together keeping exactly in time. When they fight and wreftle, they muft exactly know how to hit the

- This is perhaps the Clbinefe cbefs or fiang-ki, of which, fee Hyde Syntagna Difort. vol. II. p. 143. Feqq. et $t a b$. ad p. ₹44. F.

$$
\mathrm{R}_{4} \text { blow, }
$$




\section{TOREEN'S VOYAGE.}

blow, and to throw themfelves down with as exact cądence as in a dancing fchool., They can reprefent fome paffions as well as if they were real. One boy was once reprefenting a very fufpicious man, who was however to be very fubmiffive to his wife; and another a wife who was fomewhat of a coquette, yet knew how to make ufe of her power, and was very artful. At firt they came to blows; but when madam began to fob, cry and figh fo that her whole body flook, the hurband could hardly make her pardon him, though he fell down on his knees feveral times; and the articles of peace feemed to be very difadvantageous to him. The mufical inftruments ufual on this occafion are firft a couple of pieces of wood half a foot long, tied together at one end, and put acrofs the thumb; which when thaken, make a clattering noife like caftanets. Befides thefe they have little drums, great and fmall kettle drums, gungungs or round brafs bafons like frying pans, flutes, guittars, metal hautboys, frait horns, and an inftrument which 1 fent over formerly, and which confifts of a hemifphere to which thirteen or fourteen pipes are applied, catching the air blown into the carity by valyes. If the partoral flute of $P a n_{4}$ was not made in this manner, I do not know 


\section{CHIN A. $1751^{\circ}$}

how he could exprefs thirty-two parts. How bad foever their mufical tunes may be, yet they put a higher value on them than on thofe of Corelli : and they deferve fome commendation for their $\mathrm{kkill}$ in keeping time, for when five or fix play together you fcarce diftinguifh more than one. 
2.50 TOREEN'S VOYAGE.

\section{L $\quad E \quad T \quad T: T$ E $\quad R \quad$ VII.}

THOUGH I have taken care not to men-

1 tion what I have already found well defcribed in other authors, yet I fee from the Stockholm gazette, that I have either relied too much on my memory, or on the heads in the Englifh collections.

The Cbinefe ell, or cubit as it is called, contains about fourteen inches three-fifths. I doubt whether they have any folid meafure; since they weigh every thing, even wood and water. A pekul is about $1_{42}$ pounds and a half, Sreedif weight: 100 katty make one pekul: with this they weigh heavy goods. Gold, filver, and the like, are weighed by the

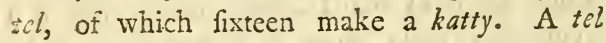
contains ten $m e / s ;$ ten kanderins make one neefs, and a kanderin weighs ten kas. Father $D u$ Halde mentions yet eight gradual lefs weights; fo that a fun, which is the leaft of all, feems only to be of ufe to thofe who will try by cutting and weighing whether matter is infiaitely diviible. They have, as is well known, 


\section{H I N A. $17510 \quad 25 \mathrm{I}$}

brafs coin of the fize of a Swedifh piece of two groats, which has a fquare hole in the middle. In value it is proportionable to the kas of filver; however, at prefent, they only give eight fuch brafs kas for a kanderin; in the fame manner as gold for fome reafons is always valued fourteen times and a half more than filver on this voyage.

THEIR fimpun, or table of accounts, is a fquare frame, which is longitudinally divided by a fmall piece of wood, not exactly in the middle. In it are $\mathrm{I} 1,{ }_{1} 3,2 \mathrm{I}$, or more wires, on which roll little balls; namely, two on one, and five on the other fide: the latter fignifies I, Io, I00, \&c. and the other two oppofite to thefe five thew the units, tens, \&c. They go on very readily with adding and fubtracting; but as for the reft, it will not do fo well. I now am forry that I cannot draw; but if I remember right there is a drawing of the fimpun in Loubere's Defcription of Siam, and befides that, I fent you fuch a fimpun the laft time. They write with a pencil, which they hold perpendicularly, between the thumb and the two laft fingers, and only lean their hand on the table, or on the paper. One would be led to think that they muft write very flow: 


\section{TOREEN'S VOYAGE.}

ly ; however, their pencil runs as quickly as the pen of one of the readieft European clerks. They have likewife a current fort of writing, which they only make ufe of when they write fart.

To keep 900,000 Cantonefe in order, no meafures can be fo effectual as thofe taken by the Clinefe. Juftice is done very fpeedily, efpecially when the fact is quite recent; but injuftice as frequently takes place.. It fometimes happens that feveral objections delay their giving fatisfaction to the Europeans. The Europeans do not eafily give up any of their privileges; but when they cannot fucceed, the fault is in the Cbinefe officers, who do not take a right cognizance of the affair. Of this you find examples in Lord Anfon's Voyage. But if one threatens to apply for juftice in higher ccurts, they are afraid that their fuperiors will punish them with heavy fines. The fale of the loweft places of truft, even that of a mandarin, is fo common, that eyery one fpeaks of it, and they venture to mention it in the moft public manner. A furveyor, who lay along-fide our thip, took a confiderable fun of money from the mafter of the boat, szith whom he lodged, for the money which 


\section{H I N A. 175 t。}

the fellow could make from our crew : and the furveyor faid, that he was forced to pay money to the cuftom-houfe officer : and fo it feems to go round. It often happens here juft as I was told it does in the Portugueze regulation of the cuftom-houfes, namely, that the revenue from it looks well on paper, but actually is worth little or nothing. The police, however, is excellent: for it keeps every thing quiet at night both in the town and on the water, where an officer goes his round regularly. The gates in the ftreets, which are fhut up at night, are always open near the factories, for the convenience of the Eurropeans: and in thofe places where in day time you muft be on your guard for fear of pick-pockets, you may pafs without danger in the night time.

IF you go further up into the town, they call you names, and pelt you with ftones, which fly about your ears.as thick as hail. If you intend to go out of town, you muft have company, walk faft, and carry a good ftick.

Borm petty larceny and theft are punithed by a certain number of lafhes with a bamboo ftich. The prifoners aie fo fettered abotit the 


\section{TOREEN'S VOYAGE.}

head and on one hand, that they cannot lift it to their head. In Auguft, in the year 1748 , they difpatched fome rebels at Canton by tying a rope twice round them, and faftening a horfe to each end, and fo cutting the body quite through. And as both high and low officers are the fovcreign mafters of their vaffals, criminals are obliged, even for trivial faults, to fuffer with the greateft fubmiffion; and on their knees to hear themfelves reprimanded, and to fuffer themfelres to be fpit on.

As for wild beafts, tigers are faid to frequent the mountains over which the northern roads pafs: for fear of them it is, that in winter nights you fee hundreds of lanthorns carried before the travellers. Their dogs can do no more than bark, little dogs efpecially. Spanifh ones are the delight of the Cbinese ladies; and their hufbands pay dearly for them: and I think there is fome hufbandcraft in it; for the affections muft be fixed on fome object.

Here are buffaloes, oxen, and theep whofe tails are a hand's breadth long, and very broad. Swine are numerous, and their flefh is daily eaten. Here are few howes, nor 


\section{H I N A. $175 \mathrm{x}$.}

do they want any, becaufe people of quality! are carried in chairs: and thofe commodities which cannot be carried in boats, are borne on mens fhoulders : and on this occafion the feeble Chine fe thews the advantage of a knack or fleight: they have an eafy fmooth ftep; and always lay the poles obliquely on their fhoulders, by which means the collar-bone is left unhurt. They can very eafily change fhoulders, and three of them know how to Thare an equal part of a weight too heavy for. two, and too light for four perfons.

CAts are very neceffary, on account of the number of mice. The Chinese judge of the goodnefs of a cat by the colour of her eyes, and their changes; for they fay a cat changes them twice a day.

QuAILs, geefe, and chicken, are pleniful. I likewife faw fome siamefe forvls, which have a double back-toe. Ducks are bred by hundreds in one boat, and at certain fignals either go out or come in. Cockado is a fpecies of white parrots, with a yellow creft (Pfittacus criftatus). They often expofe rare birds and animals to fale in the factories: but 
256 TOREEN'S VOYAGE.

I am not fond of looking at what I caninos buy.

THovg H the Cibinefe drefs ever fo light, yet they are troubled with infects. The ginats, or mufquitos, are fo troublefome to the Europeans at night, that they muft be kept off by curtains : for the place which they fting becomes painful, and fwells. A fpecies of blatias, called cockroaches in Englifh (Blatta oricntalis) are brought to Europe in great numbers.

As you are better acquainted than I am with the vegetables hereabouts, I fhall only remark that I faw no cocoa-trees aboutt Canton: perhaps they will not grow fo near the tropic; for if they could be planted here, the Chinefe would certainly not forget to do it. We took two tea fhrubs with us on our return: both of them died, notwithftanding all our care. The one was Ankay, and the other Soatcburin: the former had oblong, and the latter lanceolated leaves.

THE fmaller vefiels of the Chinefe are called fampanes. They have a flat bottom, with out a kecl, are broad, and not very deep in proportion to the length. They have feveral 
tivifions, and are fo convenient that you are fecure from rain and fun thine under the reedinats, which are fpread like an awning over the boat, and are fupported with bamboo fticks. Such boats as thefe would be very ufeful in many places of our Malar Lake. They are rowed in a peculiar way, by one or more perfons: the oars are neater than could be expected from people who have no theory in their mechanicks : in the middle it is compofed of two pieces, but fomewhat obliquely; and turns on a fwivel, fo that the oar turns both on the fwivel and in the water; and the rower need only direct it. The part of the oar which goes in the water is very broad, fuch as is neceffary to flat veffels, which have no keel to cut the water, but muift only float on it. On the larger fampanes, befides this, is a ftiff oar fixed to the bending of the Sampane, with which they may be eafily turned, even when they are deep laden. Their anchors (as is trell known) are made of wood, fometimes plated with iron on the ends; and have frequently only one arm. Inftead of the ftern, they faften a piece of wood crofs-ways to the arm, which anfwers the fame purpofe, as the angle grows tharper by the conjunction. The fails confift of mats, which are expanded by Vox. II. 
258 TOREEN'S VOYAGE.

poles, on the ends of which are ropes which come together in a knot; fo that all the parts of the fail may be pulled at the fame time.

TILEIR merchant fhips, which are deftined for long royages, are deep, pretty fhort, and will carry about 200 Swedifts tons. We call them yunks d. They are likewife without keels; and have generally three mafts, of which the greateft is fix fathoms long from the deck; without the top-nats. The ftanding ropes are made of twifted canes; the fails are up. The fpace under deck is divided into feveral partitions; and each partition is fo clofe, that if even a leak thould fpring, the fhip would not be in danger. Inftead of tow, they make ufe of a cement, which to me feemed to be mixed with ground bamboo. As the Chinefe greatly admire the figures of dragons, and prefer the moft ugly ones, their pendants have the fame form. If you go on board them, or take leave of them, they play on the gungung; but they know nothing of friking their colours, or of what is to be done on that occafion. The failois climb and tie what is needful with canes inftead of hempen ropes.

d See Lord Anfon's Voyage round the Word, Eook III. Chap. 10. Table xxxiv.

WHEN 
WHEN the whole naval force of the Chinefe Emperor is eftimated at 9999 fail by his fubjects, a great part muft be at Canton: but at that place are only great boats, which would fink with ten twelve pounders: Nor are any larger fhips of war required, while the Cbinefe gorernment has no intentions of maling conquefts by fea.

FIVE or fix of the above-mentioned boats lic about the European hips, to prevent acts of violence and fmuggling. Their arms are mields of the ufeful bamboo, litile fabres, halberts, bows, pikes of a tremendous form, for their point is almoft a yard long, and exactly like a Wefirogotbic lnife, and little flings which ftand on a kind of bow.

IT is however very amufing (at leaft for a perfon that finds pleafure in obferving the dif: pofitions of men, and their univerfal vanity) to fee fome place-men row by each other: every one who goes up or down the river has his flag and his diftinction, by which the others immediately know his rank: and if he who lies in the river, or paffes by, is of a lower quality, he muft beat his gungung firft, to $\mathrm{S}_{2}$ which 


\section{TOREEN'S VOYAE.}

which the other anfwers with the fame inftrument; after which they winh each other an happy voyage.

THE Chineje can certainly make gun-powder: neither do they feem to be miftaken when they difpute the invention of printing and of making gun-powder with Holland, Italy, and Germany. But their powder will hardly ferve for any thing but fireworks; for though it gives a report, and foon takes fire, yet it leaves a good deal of the charcoal on the paper, and feems to have but little ftrength. It is very peculiar that $\mathrm{ky}$-rockets, fquibs, \&c. and ever air-guns, may be purchafed at very reafonable prices at Canton; while the people themfelves are fo afraid of fire-arms, that they would even run from a black bamboo ftick.

If any body had told me before-hand, that water would freeze naturally at twenty-three degrees and an half of latitude, I could not have believed it. But now I had the teftmony of my own eyes, and the Swedifh thermometer. Having ftaid eighteen months in this hot climate, the cold was fomewhat troublefome in the open harbour, where we were expofed 


\section{OF C H I N A. 1752. 261}

expofed to the north eaft wind. We got clear of this and other inconveniences when we failed through the paffage at Bocca $\mathcal{T}_{\text {igris, }}$, the $4^{\text {th }}$ of Fanuary 1752. We were provided with a Chinefe pafs-port and pilot, and accompanied by many white porpoifes; and, on the 6th, we quite left the Clinefe thore. On the I 9 th of this month we were fo happy as to reach the place which the Englifh call Nervbay, which is fituated on the fouth-weft of Fava: there we were to take in a ftore of the good water of that place. Half a quarter of a Srvedifh mile from the thore is a little ifland, ealled Cantaye in the French charts, which I propofed to myfelf to vifit in our return: but, unluckily, the only time that I was allowed to go on thore, the water was fo high that I was forced to wade up to my middle; and for all my trouble got nothing but a great piece of a millepora. I was therefore obliged to content myfelf with fitting and obferving the favanese, who are Mabometans; they fpeak the Malaic language, are of a tawny complexion, and let their hair grow about as low as their fhoulders, and tie it with baft of trees. They chew betle in plenty, and are ready to run a milefor a little piece of opium. Their boats have large fails, and on the lar-

$$
\text { S } 3
$$


board a bamboo ftem, w wich is faftened to two wutriggers, and keeps the boat from overfetting, as it otherwife would do on the account of its lighmers. The faranefe brought cocoanuts, plaintains, citrons, lemties or lemontyes (as the Dutch and our failors call them), on board. The latter of thefe fruits is found to be very plentiful in all fouthern Eaft India, and is like a citron; I never faw its flower, but both Mr. Ofbeck and myfelf have always found the fruit to be ten locular e. Befides this, they had a fort of coarfe brown fugar made of palm-trees, which the crew was forbid to purchafe, becaufe it occafions ftrong dyfenteries; they. likewife brought fowls, tithes, tortoifes, fertularia, and fome daggers of good workmanthip, the blades of which wcre undulated, and, as I was told, poifoned.

THE = ift of famuliy we left this place, and experienced the weather at the Cape in March, which as ufual was very difagreeable, and thifting from ftorms to calms. We here faw one of thofe tortoifes called Hazekfoills by the

- The fume is obfervable in lemons: and this number of liculi fcems to be the moft matural in proportion to the frtals and ftumina, though they are alio found cight an.t swelve locular. D. S. See vo!. i. p. 306. 


\section{J A V A. 1752. 263}

Englifh; its head is flat, and the upper jaw like the bill. of an hawk. Its fhields lie above one another almort like fcales; on the fore paws are three nails, and on the hind feet are two. The fhell is thicker and more variegated than that of any others, for which reafon it ferves for all forts of work. Further on we faw whales, and a zoopbyte, which the Sivedes call by-de-zuind-feglare (Holothuria plyyalis); the Englifh call it man of war; the Dutch befantyes; and Dampier, if I am not miftaken, cutlers ${ }^{f}$. The body is half round, ftands directly upwards, has many long and many thort tentacula, is llimy, tranfparent ; fomewhat blueifh ; fhines in dark nights; is poifonous, as I myfelf have experienced; and fo light that it will fcarce fink in Spanifh brandy. Beyond the Cape they are fmall, in the ocean they are larger, and very numerous efpecially in March. The old failors who have often been to the $I n$ dies affirm that they have feen what Thevenot calls Carnaffe. I cannot determine whether thefe or the men of war are the true Babarras, which, according to your defire, Mr. Lagerftrom enjoined me to look for.

f Linneus places this animal among the Mollufe? clafs of his worms; and thereiore I cannot account for the author's mittake in calling it a zooplyyte. F.

$$
\mathrm{S}_{4} \quad \mathrm{ON}
$$




\section{TOREEN'S VOYAGE.}

ON our approach to the tropick, we again faw flying firhes. I mut remark that all the flying filles which I faw eaftward of the Cape had fhort pectoral-fins; and their ventral-fins were expanded while they flew, becaufe they could not otherwife have preferved an equili, brium. There is yet another fort of flying firh, which has antennas, and a veffel containing an inky matter; but I cannot tell whether it is the Sepia loligo.

This time we did not touch at St. Hclena, but bore for the Ifland of Afcenfion, where we anchored the 6th of April. This country has no other 'fref water than what the rain fometimes affords; for which reafon it is dry and barren, and only feems to be deftined by Providence to be the habitation of tortoifes, and to ferve as a placs of fome refrefhment for feamen. Goats, pelicans, and many fea birds breed here, notwithftanding the intolerable heat of the day, and the coldncfs of the night. The few low thores where we can land are covered with a loofe pcarl fand, in which the tortoifes bury their eggs. I did not fee hovy

Wot astennaz; but, 25 Limans cails them, tentaculd. F. 


\section{A S C E N S I O N. 1752, 26 马}

much the tide falls, nor could any eftimation be made, on account of the ftrong breakers; thefe are likewife fo violent againft the wind, that in 1749 a floop with four men funk very near the fhore.

I Foun D nothing particular in the Sargaffo, befides that peculiar animal, the drawing of which refembles a fpider: perhaps this was pnly the finin which fome animal had caft off.

THE 22d of May we fpoke with a Frenchman, who had received accounts from St. Hele$n a$ of fuch events as had happened during our abfence. It was peculiar, that an officer from the French Thip afked us whether the Szuedes believed in the Apoftles Creed? When a Frenchman has fuch mean thoughts of a $\mathrm{Lu}$ theran, the Spaniards and Portugueze may well think us Turks and Heathens.

THE 3 oth of May we faw the weftern iflands, or Azores, on which every one of us expected to breathe fome frefh air ; but the refolution was changed, and we failed for Englind. In the mean time the fcurvy had attacked fome of our men. It was very happy that they 
266 TOREEN'S VOYAGE.

were all Szuedes. The I th of June we faw England; and after we had bought fome refrefinments and greens, we left Dover the 19th of fune. The 26 th of fune the Gothenburgh rocks were the moft agreeable fight we had met with during a voyage of twenty-feven months.

\section{1 \\ OLOF TOREEN.}

Stromfat,

the 3 t of May, I 753 . 


\section{IIBRARY \\ NEIV YORK \\ - HiT T.NICAL \\ A S HOR T \\ GANDEN}

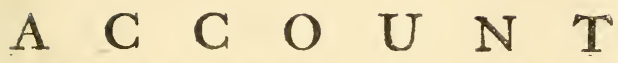

๑ F T H E

\section{CHINESE HUSBANDRY,}

\section{By CHARLES GUSTAVUS ECKEBERG,}

Captain of a Ship in the Swedish East India

Company's Service. 


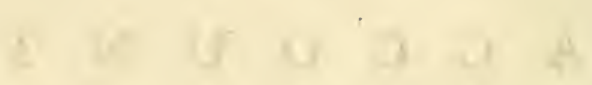

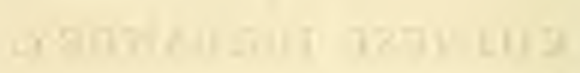




\section{9 \\ [255]}

\section{A SHOR T}

$\begin{array}{lllllll}A & \mathrm{C} & \mathrm{C} & \mathrm{O} & \mathrm{U} & \mathrm{N} & \mathrm{T}\end{array}$

O F T H E

\section{CHINESE HUSBANDRY.}

I E W countries can boaft the poffefion of 1 fuch a variety of different natural advantages, as not to ftand fometimes in need of the affiftance of others.

THIs imperfection feems to be the only tie by which civil focieties are kept together : but in China nature feems to have followed a different mode, for of this empire we may juftly fay, that it can exift by itfelf. 
ITs fituation is fo happy, that its northern parts are no more incommoded by the cold, than the fouthern ones are by the heat. Both are temperate for the inhabitants; the weather in the country, in the intermediate fpace, is mild, uniform, and accordingly pleafant to live in, convenient for health, and apt to produce all kinds of plants.

The trade-winds, which are peculiar to the fouthern and warmer regions, are no fmall advantage; for the northern one clears the air, by carrying away all the unwholefome vapour raifed by the heat; the fouthern one, on the other hand, cools the fcorching heat of the warm feafon. The greateft part of the Chinefe frontiers are watered by extenfive feas, which make good bays and harbours at moderate dittances. While nature feems to have here fet bounds to navigation, it opens new channels for it by means of navigable rivers, which extend to the innermot parts of the empire. The tide, which goes up a great way into the country, five Srecdifh miles above Canton, renders navigation more convenient; and gives the beft opportunity to the feveral towns of communicating their advantages to each other, 
by an univerfal liberty of trading with one another.

THE foil is fo fruitful, that though the hills and deep moraffes may look ever fo unpromining, yet they repay abundantly the work of the labourer: for the fpecies of corn, of roots, and fruits, which in an infinite variety fucceed each other, perfectly well reward their planters with continual harvefts.

THE great extenfive forefts afford feveral fine and precious woods, ufeful juices, bitumens, baft, and leaves, befides the feveral forts of timber and wood for other purpofes. They are likewife the habitations of many wild creatures, which afford food and cloaths for the inhabitants. Metais, ftones, earths of many forts, falt, gold-fand, pearls, corals though not of the beft fort, and innumerable kinds of filhes, which are very plentiful near the fhores of this country, thew that nature has likewife not been fparing in regard to them. The fowls, which are found every where in great llocks, delight the eyes, ears, and tafte. In a word, the empire of nature is found in the greateft perfection in China; the fineft views, fituations, and conveniences of all forts, which 
could not be brought to higher perfection by the utmoft ftretch of human invention. They have all the neceffaries of life, without wanting any thing from other countries: from all which we however muft except thofe things which may be reckoned among unneceffary luxuries.

As the welfare of a country depends greatly on good order and induftrious inhabitants, fo this empire likewife vies with many others in this particular. The induftry of the Cbinefe, and their fkill in all forts of trades, has not only been obferved in all the defcriptions of this empire, but we likewife know it from the feveral goods which our thips fetch from thence. The raw materials for thefe trades are produced plentifully in their country.

I INTEND here fhortly to relate, as a proof of. the exceeding great induftry of the Cbinefe, what I have obferved during a ftay of fifteen months, at three different times, concerning their conftant and particular œconomy. 


\section{A GR I C U L T U R E.}

\section{A G R I C U I T U R E。}

IN the fouthern parts of China, bordering upon the fea, rice, a fpecies of corn which grows beft in low and wet ground, is the principal food, and in almolt all the eaftern countries. There are fpecies of rice, which will fucceed in a higher, dry ground, as we fee here and there in Java, and on fimilar high places. This fort of rice is made ufe of by the provinces which are next to Canton, and have a dry and hilly ground; but in 2uantung, or in the fouthern low provinces, it would be a lofs to fow it ; becaufe its grains are fmall, and it takes half as much time again in ripening as the other fpecies does: and, on the other hand, the other fpecies has larger grains, grows better and quicker, and can, without any damage, ftand continually under water. Of this fort there is a more coarfe variety, which looks reddih, and is eaten by the common people, and likewife ufed to diftill the brandy from, which they call famfu.

I HAVE been told that the further you go to the north, the more you find the culture of VOL. II. 


\section{CHINESE HUSBANDRY.}

rice decreafes; and that rye, barley, wheat, beans, peafe, \&ic. are cultivated inftead of it ; for which reafon, the inhabitants of the northern parts, where rice will not grow at all, are faid to be well acquainted with the management of the laft mentioned different fpecies of corn.

THE fouthern provinces likewife produce fome wheat, beans, fmall peafe, and lentils, which the inhabitants either make ufe of themfelves, or fell to foreigners. But rice is fown more plentifully; and as it is ufed inftead of bread about Canton, I thall fpeak more particularly of it.

It has already been frequently demonftrated, that Cbina is exceedingly populous. Moft parts of the country are fo crowded with habitations, that you are amazed to fee the land able to produce fufficient corn for fo many millions of inhabitants; and efpecially as they are not fupplied with it from other places, except by a few junks from Cocbin Cbina, or Malay, and fometimes (but rarely) by a few Dutch hips. But when one comes to refleck upon their almoft incredible induftry in cultivating and ufing every thing which can be made 


\section{A GR I CUL T URE. 275}

triade ufe of, and on their fparing and tempe: rate way of life, it is a convincing proof that a country can never be too full of fuch inhabi: tants, fo as to want the neceffaries of life. Rather, it is the number of induftrious men; that contribites to the riches of the country; and to the comfortable fubfiftence of its inhabitants; for every induftrious labourer, efpecially a huifbandman, altvays produces more from the grateful foil than he wants for himfelf.

THE pitch to which agriculture, ànd efpecially the culture of rice, has been carried in Cbina, is the principal foundation of the happinefs of this country. Husbandry is much refpected here, and has the greateft encous ragements. The emperor himfelf, to thew the value he fets upon it, and to exhibit an example to his fubjects which deferves to be followed, goes annually, or a certain folemn day, into the field, attended by the noblemen of the court, takes up the plough, prepares and fows a piece of ground, and afrerwards reaps the corn with his own hands. But I muft confine myfelf only to the environs of Canton.

$$
\text { T2 EARTHS }
$$




\section{CHINESE HUSBANDRY。}

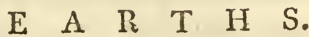

THE foil is as different at Canion as in other places, according to the fituation. All low grounds are covered with clay and black mould; but the higher the ground rifes, the more a yellow and reddih ochrous earth, glimmer, and fand, prevail : when fuch a foit has been left uncultivated and untouched for a while, it acquires, by the vicifitudes of rain and fun-fhine, as it were a petrified furface. Notwithftanding this, pines, and other bituminous trees, grow very well on it; and fome not very. tender plants, which in our country grow on old walls, and on high rocks, friking their roots into the cracks: this thews, that the earth on the hills, which is expofed to the winds and heat, is difpofed to produce plants, though the rain wafhes away its manure.

The river $\mathcal{T}_{a}$, or $T_{a b o}$, which runs into the fea below Canton, the water of which is hereabouts a mixture of freih and falt by the tide, divides the country for the diftance of fome miles round about the town, into many greater and lefs inlands, whofe nores are broad, 


\section{E $A \quad R \quad T \quad H \cdot S$.}

broad, flat, and folow, that for fome hours, when the flood is at higheft, they look rather sike great feas than like corn fields. This continual humidity muft naturally make the clayey ground fwampy and moraffy, and accordingly the husbandmen muft be up to their knees in it when they work, before they can get a folid ground.

IT fhould feem that a foil which is every twelfth hour under water, muft be entirely deprived by it of all fatnefs and power of producing corn, and become unfit for cultivation: and that even when the water fhould bring fomething on it, it would again be wahed away when the water runs off; and that therefore manuring would be of no ufe. And insleed the wet rice-fields get no other manuring than the ftumps of the rice, which are dug in and left to moulder. Notwithftanding this, thefe fields annually produce a very plentiful crop. As often as the water overflows the fields, it leaves behind it a flime which makes the foil fruitful; for the tide, which comes up from the fea, is more faline and dirty than the $e b b$, which is clearer when it runs off ; befides this, the ebbing retires at firft but llowly, and is already run off from the rice-fields before

$$
\text { T } 3
$$


it quickens. its pace; confequently the faline nlime, which has fettled itfelf and becomes mamure to the fields, cannot be wafhed off again.

\section{RICE-FIELDS。}

THE rice-grounds are fo foft in fome places, that the flood carries away the foil from the thores: to prevent this, they are planted with cypreffes, whofe roots being twined among one another give a confiftence to the earth. And as each great rice-field is feparated from the river by broad ditches, thefe long rows of cypreffes make a very fine fhew, efpecially when the field is under water.

THEY have a different fort of rice-fields in higher places, fuch as cannot be watered by the flood. About each of thefe fields they make, for the fake of watering, a dyke two or three feet deep, within which they cither collect or let the water run off in the rainy fearon, as they think proper, but in the dry feafon they convey it to thefe fpots. The foil cf thefe fields is a mixture of a ftrong clay and mould: and as the annual produce thereof may be double that of the others, they 
they are fupplied with feveral forts of manure, and are better taken care of.

BESIDES this, the Chinefe make rice-fields from fwamps and brooks; but fince thefe cannot be kept uniformly moift without great expence and trouble, they generally mifcarry in dry years: Some perfons of credit among the Chinefe have told me that the river in the province of Tockian, which difcharges itfelf at Schangthey, forms great flat fhores, and that the inhabitants (difpleafed that fuch a confiderable piece of ground fhould be ufelefs) built rafts, fpread mats over them, and carried foil and laid upon them, and then planted rice, to their great advantage. When the winds fhifted, they fuffered fometimes from ftorms: but this contrivance was reckoned very advantageous, becaufe they had always a uniform degree of moifture from below, both in the dry and wet feafon; and in the latter feafon they did not fuffer by the rain, becaufe it ran off foon. This is an invention and a proof of their induftry, which deferves admiration.

THE preparation of all the afore-mentipned rice-fields is effected either with the plough, or with a beck-hoe to break up the ground.

$$
\mathrm{T}_{4} \text { Both }
$$




\section{CHINESE HUSBANDRY.}

Both methods have the fame effect, fince the whole bufinefs required is to remove the old rice ftumps, and turn them under ground; for, as the ground is always fo foft that the labourers muft wade up to the knees in it, the work is very eafy. Their plough is very fimple, and is drawn by an ox; but with the beck-hoe they can likewife penetrate as decp into the foil as they think proper, without much trouble. By the next tide the ground is made as even as if it had been rolled; and as the continual humidity of the foil hinders the ground from binding together, they want no other tools. All other forts of arable fields are prepared in the fame manner, fince they choofe that time for cultivation when the ground is moft foftened by the wet, and accordingly can be snoft eafily managed.

THEY manure, plough, and prepare a little part of a field, about 60 feet fquare, either more or lefs, which muft be as the other ground, wet and fwampy, but at fuch a diftance from the river as not to be expoled to inundations when the water is high in the river. They fow it very thick with rice, which is firft foaked in water, in which lime and dung had been previoufly put. When 
the rice begins to come up, they keep the field about a hand's breadth deep under water; and after thirty days the rice plants are ready to be tranfplanted into larger fields.

THEY are not very curious in tranfplanting, to place the plants in ftrait lines; but very careful that every rice plant has the neceffary room, which is generally about eight or nine inches from one another. The tranfplanting itfelf is tranfacted (as all their other bufinefs is) with great eafe, and in fuch a manner, that they crop off about two inches from the top of the plants, and plant each by itfelf: but when they are too fmall, they plant feveral together fo deep into the foft foil, that the roots immerfe full two inches. When the rice is tranfplanted in this manner, they do not meddle with it any more, except that now and then while it is yet tender, they examine whether the worms and little crabs do it any damage: in which cafe, they fupply the place of the deftroyed plants with frefh ones, and afterwards fpread fome lime, which annoys thefe animals, 


\section{MONSOONS and WEATHER.}

THE fouthern parts of Cbina, within the tropick of Cancer, are fo much influenced in their weather by the neighbouring monfoons, as to have the year divided into two feafons, the wet and the dry. When the fun in Septemioer goes to the fouthward of the equinoctial line, the air cools by degrees, and October and part of November are generally wet, with fogs and drizzling rain. As foon as the wind turns N. E. the $\mathrm{ky}$ clears up, and becomes free from vapours till this wind again is quite fettled. In the following months the weather is more conftant, till the fun again returns from his winter courfe, and paffes the equator in March, going to the north.

THE heated air, which has by little and little drawn up a quantity of moifture, returns it again in heavy fhowers, which alway grow ftronger in May and Fune, and are fo continual that fometimes you can count twelve or fourteen rainy days one after another. Thefe very heavy rains are generally attended with violent thunder and lightning, and hurricanes from fouth to weft. 'Though the fun begins 


\section{W E A T E R.}

in Fune to go to the fouthward again, yet he leaves behind him in thefe places a greater heat than what he caufed when he was perpendicular to them. The weather however begins to be more conftant, and the number of fair days rather encreafing, notwithftanding the heat declines more fenfibly than before by the inconftant weather, attended by clouds and intermittent winds. Auguft is more temperate, but has changeable weather, fometimes calm, fometimes foggy, till towards the beginning of September, which continues till the other wind fettles. According to this view, their rainy months are April, May, and Fune: for the rain then falls more plentifully, and in fuch quantities that the water in great rivulets rolls down the fteep places, and opens new roads and ways for itfelf in the rocks. On account of the drynefs which may be expected in the following months, the inhabitants condukt this water into their rice-fields. We muft here remark, that the fhifting of the winds about the time when days and nights are equal, feldom happens without a fort of violent ftorm, which generally blows two days before or after the change of the moon. The lower air then grows exceedingly thick and full of $f_{1} \mathrm{~g}_{2}$.which on account of the violence 


\section{CHINESE H USBANDRY.}

of the wind cannot become rain, but is hurried about with great violence. The ftorm increafes as the wind tacks to the weftward; and when it is become quite wefterly, neither trees nor houfes are always fecure: it changes ftill from one point of the compafs to the other, till after twenty-four hours it begins to abate. Such tempefts feldom pafs over without doing fome damage among the fields, boats, or houfes; for which reafon the Chinefe call it tay fong, or the great wind.

THE Chinefe know how to avail themfelves of this periodical weather, to the great advantage of their agriculture. They work the foil when it is wetted by the autumnal weather, and is yet foft for planting, or receiving the winter-feeds; this happens about December: and the air being then cooler, the water cannot dry away fo foon, but that it muft forward both the growth and the crop, fo that the latser may be perfected in a hundred and twenty days, that is, in April. The ground which is then again foaked by the rainy feafon is manured a little, ploughed, and made ready for the fecond reception of the feeds, or planting: the ufual time for the fecond preparation of the fields in the fame year, is either towards 
the end of May or beginning of foune. One fhould imagine that the vicifitudes of rain and warmth would now more forward the growth of the rice, than at the time of the firft crop: however, they are obliged to wait longer this time, and to count a hundred and thirty days from the planting to the reaping of the rice; for which reafon the harveft falls out in September.

THE low grounds are planted with riceplants, towards the end of April or beginning of May. This crop requires as many days to ripen as that on the other fields; and the crop generally becomes ripe in September. Afte: this, the ground is not ufed till April, during which time the ftumps and roots of the riceplants are fo mouldered, that they quite become earth at the time of ploughing.

As foon as the rice begins to grow white, it is cut with fickles, (the blades of which are dentared like faws), bound up in theaves, and carried to high dry places, where it is dried and put under cover till it is to be threfhed. The threfhed rice is yet in its hufk, and is called paddy; it is either ufed for feed, or as fodder for the cattle; but hefore the people 


\section{CHINESE HUSBANDRY.}

ufe it, they pound it in ftone mortars with wooden peftles, and cleanfe it from the loofe chaff by winnowing.

Some hurbandmen, who have larger fields than they choofe to cultivate, let a part of them to poor people at a certain rent. Thefe tenants are riot men of fubftance enough to be able to till the fields with ploughs and oxen: for which reafon they make ufe of the beckhoes, buy of others the neceffary rice-plants for tranfplanting, threh the reaped rice under the open fky on naked rocks and hills, cleanfe it, and pay the rent to their landlords with it.

\section{U N G.}

IN order to have a fufficient quantity of dung, where agriculture is fo extenfive, many poor people get their livelihood by gathering: all things fit for manure; the excrements of men and beafts, in the ftreets and about the houfes, and likewife along the fhores of the river, which they collect in little fampanes. They fell what they have got to others, who again fell it to the hurbandmen who are in want of it: and for the fame reafon they coljest 


\section{$\begin{array}{lllll}D & \mathrm{U} & \mathrm{N} & \mathrm{G} & \end{array}$}

lect urine in proper veffels which they keep in their own houfes. If the crop has been good a pekul of the firft fort of manure cofts two mes; and the fame quantity of the latter, only half that price. Befides this, every hufbandman takes care to make ufe of the excrement which his beafts drop on the paftures: children and fuch people as cannot do other bufinefs, gather it. They likewife pick up all bones, burn them, and fpread their afhes, together with the anhes of burnt plants and boughs, over the fields, to promote fertility.

Such fields as are moif, but higher than thofe whereof we have till now been fpeaking, and confift of deeper mould, are manured, ploughed, and laid very fmooth. In fuch a field they fow wheat very thick together, having before foaked it for fome days in the filthy water of a dunghill; afterwards they tranf. plant the plants. Sometimes this foaked wheat is grain by grain planted over the whole field, fo that each grain may fand four inches from the other. The foil is thrown up in ridges towards the grain. In a great drought a little water is brought over the fields, by which means the deep furrows occafioned by cafting the foil up towards the wheat, receire the

water, 


\section{CHINESE HUSBANDRY.}

water, and give moifture to the plants, without drowning them. The true time for tranfplanting is towards the end of December, and though the air is then very cool, and it fometimes freezes in the nights, yet the feeds thrive, and the plants ftock out in a fortnight; each of which brings forth in March feven or nine ftalks, with ears and ftraw, rather fhorter than ours; and in May there is a plentiful crop. I have been told that wheat produccs a hundred and twenty fold; which increafe plentifully rewards the hufbandman's labour and trouble.

As rice is what the Chincle chiefly fubfint on, and what they ufe inftead of bread (as has been before mentioned), they employ but fmall fpots of ground for the culture of wheat. They only ufe it in their fugar cakes, a great quantity of which are requifite for the pagodas on their holidays; and fome they make for themfelveș. Foreigners eat the chief part of this corn; and becaufe that which is rafed in this province is infufficient, large quantities are brought from the northern parts.

I saw fome barley on a little ficld in June; it girew very well, and Lhot out exceeding fine 
ears: but becaufe it was fown too late, the encreafing heat made it thrive too faft, fo that it grew pale before it could fet the grains, and only contained fhriveled hufks in thofe fine ears. If it had been fown like the wheat in the cooler feafon, it would undoubtedly have afforded a plentiful crop. From thence I cuncluded that as thefe fpecies of corn fucceed exceedingly well, when fown and tranfplanted in a well-prepared moift field; fo the cool weather muft be more ufeful to the growth than the hot.

THE manner of threfhing rice and wheat is the fame, 'and is performed as in our country with flails. The wheat after it is threened is paffed through a kind of fcreen for cleanfing it, which carries off all the duft, before it is ground. If the mills at Canton were made as convenient as thofe machines, the people might fave a deal of trouble; but the method of grinding with hand-mills is exceedingly troublefome. It is peculiar, that the Chinefe have many pretty inventions to make little works more eafy; but in greater works, fuch as fawing, grinding, and the like (which require greater powers), they do every thing by the hand; though they have fufficient opporVOL. II. 
tunities of making machines, both on rivers and hills.

In the afore-mentioned manner they till all flat and low places, and find little trouble with the foft ground, which they always keep pretiy level. The general produce is a hundred from one; but when irregular weather happens, and it is either too dry or too wet, a fterility enfues, in the fame manner as in other countries: but in this country it is attended with worfe confequences. A little increafe of the value of rice frequently occafions a murmuring among the lazy and poor, which at laft, if the number of malecontents increafes, turns into a rebellion againt the $T$ artarian government; as happened in $175 \mathrm{I}$, when the famine was accompanied by an epidemic difeafe, which carried off a great number of people.

\section{ARABLE FIELDS ON RISING G R O U N D S.}

THe natural fituation of hills and of declivities would make them incapable of producing any thing: for either the continual rain 


\section{R. ISING GROUNDS. 291}

in the wet feafon would drown or wafh away all the feeds; or the plants, when deprived of earth by the wafhing of the water, would be too much expofed to the following heat and drought. To prevent thefe inconveniencies, the Clbinefe have endeavoured to reduce the hills into plains, or at leaft to make them fimilar to plains, by terraces, whofe height and breadth are adapted to the declivity. Thefe terraces they employ for feveral forts of plants ${ }^{\mathrm{h}}$; and to each they give fuch a fituation as beft correfponds with its nature. Thofe which can bear the greateft drynefs are difpofed at the top; the more tender ones at the bottom. When the rain has foftened the foil in the upper terraces, the water is conveyed by canals into the lower ones; which therefore, befides the rain which falls upon them, receive likewife the fuperfluous water of the upper ones.

THE terraces, which are fometimes four or five feet above one another, acquire fuch hard folid banks by rain and funhine, that they would ftand for many years. However, they have planted them with fereral trees, whofe

h In this manner did the Feivs in the Holy Land cultivate their hills. See Maundrel's Travels. 


\section{CHINESE HUSBANDRY.}

roots twifting together keep up the borders; and the trees themfelves thelter the plants from winds and funfhine, and fo give a very fine appearance to thefe decorated terraces.

WHEN the foil of the terraces is dug up by a little plough or fpade, and made fmootl with a little rake, they at the fame time put fo much dung as the plants require: yet in this cafe they likewife are very fparing. The dung is generally foaked in water in round cifterns funk in the ground; and the feed is moiftened with this filthy water.' Sometimes when they plant or fow they lay a handful of afhes on each grain, becaufe in their opinion the dung which lies between the plants does no good.

TнE beds which are made on the terraces, or in other places, fcarce lie ftill one month; but foon after the ripening of one plant are prepared to produce another; and are annually employed three times. The hurbandmen regulate the bufinefs according to the nature of the plants; and each plant, which either loves wet, cold, or drynefs, obtains the moft convenient feafon to grow in; and all the roots come in autumn. 
THE fpecies of feeds which were generally fowed on the aforementioned terraces are the following :

A cOARSE fpecies of a plant with thin roots, whofe leaves, flowers, and feed capfules, were like thofe of radifhes. Thefe were fown in the beginning of December; when they had levelled a field, they dug furrows of a foot broad, and of half that depth, making long narrow beds of half a foot broad at the top. By means of thefe furrows the fuperfluous water runs off, when it has fupplied moifture enough. The feeds were put an hand's breadth deep, and feven or eight inches diftant from each other; allowance being made for fpreading in their growth. As this is done in the dry feafon, they water the plants at firft. In February they were all in bloffom; but in April the feed capfules turned yellow, and then the plants were plucked, dried, and the numerous feeds beaten out. From the feed they prefs an oil, which they turn to many purpofes in ceconomy; but efpecially they burn it in lamps, and drefs feveral difhes with it while it is frem. The oil is fo fat that it cannot be ufed in paining, becaufe it will not 
dry. The foot, which comes from the lamps in which this oil is burnt, is ufed in making the well known Indian ink.

Commonuy the feeds of cotton (which they call minfoo) fucceed to thofe oily feeds. The foil for it is prepared as before, and the feed is likewife put into the fame forts of narrow beds, a foot afunder; it muft be obferved, that according as the plants either thrive or fpread more or lefs, the beds likewife are made either narrower or wider; and alfo cither further from or nearer to each other. They are fown in April, over each feed they throw a handful or two of afhes of the oil plaut or of other plants : and this is all the manure the field has at this time. They are watered in dry days till the fourth leaf appears. Warmth and rain change the flowers, which appear in "fuly, into pods in Auguft, which open in diy weather, and thew the cotton; they are then broken off, the feed feparated from the cotton, and preferved for the next year. IToo much wet is hurtful to the cotton plants, both while they grow and while they ripen; and the cotton capfules hang mouldering on the ftalks during a continual rain: and for this seafon they feldom have fo plentiful a crop of 
RISING GROUNDS. 295

this as of the former. This feed is a delicate repant for mice; they not only feek for it when the pod is expanded, but likewife feed on it when in its capfules.

Potatoes (which they call fowcec) make the third and laft crop which they plant on the terraces. The cotton crop being over, they prepare the ground as before, and place the flices of potatoes about one foot and a half afunder. As this plant is not fo tender as the former, grows flowly, and bears the cold, fo they leave it to increafe for the remaining months of the year. Thefe potatoes are in fome refpects different from ours. The roots have red peels, are longer, yellow, fweet, and agreeable to the palate; but the leaves, \&x. are like thofe of the Europan potatoes.

THEy do not always fow oil feeds, cotton feeds, and plant potatoes, exactly in fucceffion one after another; but fometimes fupply the place of cotton with lentils, beans, locktaw, and calvanfes: but they commonly begin the annual cultivation of their terraces with the oil feeds, and finilh with potatoes. 'They always prepare the ground as has been before mentioned; nor do they fow a fingle feed which 
296 CHINESE HUSBANDRY.

has not for a day or two been foaked in the wate of a dunghill, or in lime water.

YAMs, which they call ootaw, are planted like potatoes; but the ground fuitable to them mult be different: for thefe roots are fet in fwampy wet places which are unfit for other ufe, and fometimes on a rice-field which has already been cropped, and which is not worth fowing again with rice the fame year. The, longer the roots ftand in the ground, the larger they grow; they are generally taken up in November.

THE roots of the fugar-cane cut inta pieces, (each of which had a thoot or two) were planted more than half a foot deep into the ground; and two feet fpace was left between every two rows. They planted them both on the higheft terraces, and in the loweft places, In Marcb and April thefe roots were planted in the low places, and in the rainy feafon on the hills, which occafioned two different crops. Thefe canes were by no means tender; for they throve in thade and funfhine, wet and dry, heat and cold. When the canes began to grow yellow, they were cut; for when they ftood longer, they grew mouldy at the root. They 
RISING GROUNDS. 297

grow from eight to twelve feet high. Some fampane cargoes of canes are brought together to a convenient place on the river fide; there they build a hut of bamboo and mats, at one end of which they make a furnace with two great iron-boilers; and at the other an even floor of a confiderable fize laid with planks, over which two oxen draw an angulated roller of hard wood. The canes, which are difpofed in layers under the roller, are crufhed; and the juice, which by means of a canal is conducted to the end of the floor, is there collected in a great veffel. The remaining juice in the canes is entirely boiled out in one of the boilers, is mixed with the expreffed juice, both are ftrained through a cloth, and boiled into a brown fugar in the other boiler: the leaves and ftalks ferve as fewel. When no canes remain in the place where they are, they remove the houfe again, and proceed further with all their implements. Thefe fugar-bakers travelled about in the country, and boiled the fugar out of the country people's canes, leaving it, to be refined by other fugar-bakers, and made into fine and coarfe powder-fúgar. 


\section{K I T C H.EN GAR D E N S.}

My account of kichen gardens will not be fo compleat as I could wilh, becaufe I have had no opportunity of feeing any befides fome very indifferent ones. What I can affert relating to them is, that they generally choofe low clayey fpots to make them in, and that they manure them well. The known plants were fallads, long and fhort cucumbers, lceks, wobile onions, fpinage, celcry, carrots, orach, a species of watery turneps, long radiflos, gourds, and water-melons: thefe they cultivate in the gardens, having procured the feeds from the Portugueze. But befides thefe we meet with feveral fruits, whofe names and thape are quite unknown to us. Purfane grew wild; they did not ufe it themfelves, and therefore made no account of it. They kept a coarfe fort of water-fpinage in ponds about half a fathom deep, in which it grew fo plentifully, that it quite covered the furface of the water; this is one of their molt ufual pot-herbs.

THEY plant pieces of ginger in a clayey foil about it hand's breadth deep; this they do 
in February or March; for when it is done later, the heat forces the ftalk and leaves too much, and makes the roots more fpungy and fmall: in other refpects it bears both cold and heat.

THEY call tobacco yeen. The cultivation of it is the more advantageous in China, as it is there more efteemed than in any other country; they therefore neither fpare pains, nor think any foil too good. In March the plants are fet a foot and a half afunder : in Auguft the tobacco is ripe, and then shey pluck it, make it fweat, and manage it as is ufual with us. This tobacco does not feem to be the beft; for though it looks like ours, yet both its fmell and its tafte are difagreeable: the Chinefe prefer it to that of Manillas and Aynam," which in goodnefs equals the Brafilian tobacco. The dried brown leaves are laid one upon another in a prefs, and afterwards are cut into fmall ftripes, with a broad iron plane; and in this fhape they fmoak the robacco here: when it is fmoaked, it leaves behind a vifcid ftinking oil; it burns better when it is cut into greater pieces. The fale of this commodity is fo great, that a large quantity 
300 CHINESE HUSBANDRY.

quantity of it is fent to the neighbouring parts.

THEY had fet a plant unknown to me, called Fockyong, not unlike mint, but with paler leaves; it was planted on broad beds in rows, and it was a foot high in March. The culture feemed very tedious; for on account of the heat it had been fown in the cold feạfon, and was at that time quite furrounded with mats. They valued this plant very highly, and fold a pekul of it for 50 tel. They pretended that it was of exceeding great fervice in confumptions.

Tre greater and lefs Palna Chrifti (the lefs in particular, Ricinus) were planted every where, without any order, in the gardens at Aynam. The kernels being preffed, afford a white clear oil in plenty, which they deprived of its fatnefs by minium, quick lime, and vitriolic earth, and boiled it into varnifh, which when laid on, dries foon and gives a fine glofs.

InSTEAD of cabbage, they ufed a plant with great coarfe leaves, like thofe of burdcck, all iffuing out of a little root. The 


\section{KITCHEN GARDENS. 3or}

yellow flowers, the ftalk with the pods, and the feeds themfelves, were like cale. They daily ufe this plant, and therefore it went off fo faft, that they immediately fowed the void beds with it again. It grew very faft in all feafons. They half boiled it, dried it, and took it with them upon fea voyages. Befides this, the Tartars of Pekin had a fpecies of white cale, with long narrow heads, which was not yet very much in ufe, and therefore was fcarce.

\section{THE CULTURE OF TREES.}

THOVGH there are many good fruit-trees here, I could not obferve that the Cbinefe did much regard their culture. They had planted feveral trees, and among thofe likewife fruit-trees, about their gardens and terraces; and likewife had made great orchards, which they looked upon as very magnificent; for which reafon, they were generally planted before the pagodas and places of diverfion. But few of the fruit-trees, or other trees, are known to us. 
SW E I T orangc-trees (which have been brought to Europe by the Portugueze) were found bearing good large fruit: and it was faid, that they came to ftill greater perfection in Fockien and about Amoy. Here are feveral forts; fome of the fize of a walnut, others of the fize of an apple, others were angular and reddilh, \&c. In a few places only, I found thofe trees placed in fome order, in rows, and managed as they ought to be. But, if they were guarded from frong winds, they fucceeded without any further care, and bore fruit plentifully. Fockien and Quantung are obliged to fend annually a confiderable quantity of fruit to the court at Pekin.

I.EICKI is a fpecies of trees which they feemed to reckon equal to the freet orange trees; there are feveral forts of it, fuch as great, fmall, and wild ones. The fruit was of the fize of nutmers, furrounded with a coarfe, knobby, reddifh thell, and growing in bunches like grapes. The trees grow as high as pear-trees, and are furnifhed with narrow, cufpidated, prickly leaves: they preferve the berries dried, and eat them as raifins. It feems hardly credible, that the country about 


\section{CULTURE OF TREES. 303}

Canton (in which place only this fruit grows) annually makes a hundred thoufand tel of dried leickis.

$T_{E A}$ (which they call $c b a$, and which hereabouts grows only upon an ifland directly oppofite Canton) is efteemed for ftrengthening weak lungs: the ifland is called Honam, and the tea therefore has the name of Honam tea. The bufhes, which were two or three feet high, ftood in rows on dry fandy hills. The light-green foft leaves were plucked in $M a r c h$, and roafted in iron kettles, and rolled up as other teas are ${ }^{i}$. The harfh dark "green leaves were left hanging. It feemed as if they had taken too little pains with thefe fhrubs, for near one half of them were dricd up.

The areca tree cannot grow far off Canion, as I fhould imagine by the frefh nuts which were expofed for fale. At Aynam were fereral plantations of this tree, ftanding in ground that was moift and fat. The trees themfelves are not unlike cocoa-trees, and have ftrait ftems. When the fruit was ripe, the fhells affumed a burnt yellow colour, and then the nuts, which are like nutmegs, are taken out, dried, and fent to the north.

i See noie, vcl. I. p. 25 c. 


\section{CHINESE HUSBANDPY.}

THE betle buthes were likewife not tender; for they grew fpontaneoufly without being planted, wherever they found a convenient. place: its leaves, being covered with chalk and rubbed with a piece of areca nut, compofe the known pinang, which this and many other eaftern nations chew with great relifh.

THE mange tree grows high, with expanded branches, like the afh: the leaves are like thofe of our (the white beam) cratagus aria, and the fruit is reckoned the moft wholefome of all the fruits in the Indies.

Citrus decumanus (the fhaddock, pompelmus meift. itin.) is a fort of great fweet citrons; the tree is like the citron-tree, but the leaves are broader. There were alfo little four citrons, longan, and other forts of fruits ; and likewife otomkboo, from which, as Le Comte relates, they get the refin for their varnifh. There are olives, pear and apple-trees, and likewife grapes, all which it would be tedious to mention and defcribe. It cannot be faid that any of them enjoy the preference in regard to culture; for they are all of them left 
C ULT URE OF TREES. $30 S^{\circ}$ to grow of themfelves, as if they were wild: in fome forts of trees they make ufe of grafting, at which they are very expert.

\section{GARDENS for DIVERSION.}

As great a difference as there is between the tafte of the Cbinefe, and that of other nations in their cuftoms, drefs, and other things, it is full as great with regard to flower gardens and thofe intended for diverfion. They take very little care about flower-pieces, hedges, covered walks, and fymmetry; they are better pleafed with a naked place, laid with ftones of different colours and fizes in the figure of dragons or flowers, than if they were adorned with pretty defigns, and the fpaces filled up with plants or grafs. Their walks muft likewife not be open; but generally they are inclofed with walls, on the fides of which vines and other climbing plants are planted; which being ftrained from wall to wall on poles, by this means form a covered walk. The benches made in thofe walks are not lined with walls on the fides, and, by the peculiar confruction of the ftones, they are provided with fereral holes in which they place pots with different flowers. The walks have many bendings; Vo L. II. X fometimes 


\section{CHINESE HUSBANDRY.}

fometimes they pais over a little fmooth place covered with ftunes, and lead to an open fummer-houle, on which there are flower pots; fometimes they form arched walks, which are doubly twifted with thin bamboo, but in an irregular way; and between it a fort of bufhy ever-green is planted, which twines in among them, and makes them look like a green wall. Befides this there are many various fcenes-: hills covered with bufhes, below which run fome rivulets, furrounded with clofe ftanding fhady trees; buildings which are three or four ftories high, and generally open on the fides; towers, rough grottoes, bridges, ponds, places fown with beans; thick and wild buhes or little thickets, and other varieties which afford a fine landfape. Sometimes they have low ftone feats under the thade of fome great trees, from whence they can furvey a great part of the country.

ThougH their gardens are very large, yet they appear ftill greater by their winding walks which turn backwards and forwards. From as much as can be judged of their tafte, it appears that no part muft be fimilar ta another. In fome gardens they dig ditches, round which a walk leads to all the abovementioned 


\section{GARDENSFOR DIVERSION. 307}

mentioned places; near them they have many fummer-houfes, which are all of them of a different conftruction, and are commonly near a pond on one fide, that they may catch the fifhes contained in it through the great windows. In the fummer-houfes they have gold and filver fifhes in little ponds; and befides them, birds and other animals, flowers, figures of dragons, with many other objects more pleafing.

\section{BEASTS AND BIRDS.}

$T_{H E}$ people about Canton and on the fea coafts have feldom any ftock of great cattle, becaufe they do not reckon them fo neceffary as in the northern and adjoining provinces; for they can till their ground with very little trouble, and without cattle; and they travel and tranfport every thing by water, being much affifted by the tide. Beef is not a very agreeable difh among them, and the plenty of fifh fupplies its place. But few people have horfes, except the Mandarins and foldiers. They ufe only oxen and buffaloes in tilling the -ground, efpecially in places at a great diftance from the fhore; they keep cows only to

$$
\mathrm{X}_{2}
$$

preferve 
preferve the breed, becaufe they feldom make ufe of the milk. Some years ago they made little account of great cattle; but fince the $E u_{\text {- }}$ ropeans have been more numerous here, and ufe every year a good quantity, not only in Cbina but likewife on their return; they have been induced to keep more great cattle, on account of the flefh and the milk.

Sheep are not fo numerous about Canton as in the neighbouring provinces. Their fkins and wool are ufed as cloaths in the cold months; they are however dear enough, fince every body cannot keep cattle, efpecially theep.

Asses are not fo commom about Canton as they are higher up the country, where they are ufed for working and travelling. The Tartars have fuch a great liking to affes flefh, that they have introduced the cuftom of killing them, and eating them as they do horfes: I have likewife feen them fell this fort of meat here.

Althocian they greatly neglect the laft mentioned animals; yet they efteem the lefs animals much more, which they can keep with. lefs trouble, and more-advantage. Long experience 


\section{BEASTS AND BIRDS. 309}

perience has taught them to manage them to fo much advantage, that little families have a fufficient, and even fuperfluous, maintenance from this bufinefs.

THEY keep plenty of hogs, whofe fiefin they eat daily in great quantity and with great relifh, and the fpecies in this country is very prolifick; for the fows farrow before they are one year old, though they do not produce fo many young ones at the firft time, as the third or fourth, when the fow brings forth generally feventeen or eighteen pigs at once. The diftillers of famfu, riceftampers, and thofe who have mills, always keep many fwine: though not fo many as the people on the fhore, and the fifhermen, who feed them with fin without any expence to themfelves: but this food gives them a fifhy tafte. Befides this, every little family in the rampanes keeps hogs for their own ufe, and for fale. It can hardly be imagined how a fufficient number can be bred, when you obferve what quantities of pork they carry about the ftreets, and daily confume (fince their principal difh is prepared of bacon); and likewife that they facrifice large whole roafted fwine in the pagodas, and ufe them on holidays; befides confuming many on

$$
x_{3}
$$

their 


\section{CHINESE HUSBANDRY.}

their fea voyages, and likewife by felling them to the Europeans. The pigs of the firt and fecond breed are always fmall, like the fows. which pig early; and for this reafon the female pigs which are deftined to be killed, are caltrated.

THEY keep many chicken, but more for foreigners than for themfelves, and are well fkilled in making capons. They leave the chicken to be hatched by the hens, and do not make ufe of ovens. The warm weather and the many eggs which the hens lay, greatly contribute to their conftant fuccefs.

Though there are pheafants about Canton, yet they are not fo numerous as higher up the country, where they are very fine, and of feveral colours. They are brought to Canton as rarities, and are fold at a great price.

TUREEYs are not bred in Cbina; and though fome of them are annually brought from the Malabar and Coromandel coaft ${ }^{k}$ (which is the native country of thofe birds), yet they have not taken pains to introduce them.

k Mr. Toreen, in his fourth letter, has thewn that thele Wirds are not natives of thofe places. F. 
ALL forts of pigeons fucceed and multiply greatly here.

THE geefe thrive well : they are lefs than ours, and like our wild gecfe; fo on the contrary their wild geefe are like our tame ones.

THEY are perfect mafters in the management of ducks. The breeding of thefe birds is a thing of the next confequence to the breeding of fwine, which the Chinefe take fo mucl pains about: and as ducks are a daily dith at the tables of people of quality, the great confumption thereof requires a great breed. The continual warmth of the weather, and the conveniencies of the river, greatiy promote their growth : for they can be fed at a trifing expence, with little fry, and crabs which remain on the rice-fields after the water is run off. Many people at Canton earn their fubfiftence merely by bringing up ducks; fome buy up the eggs and trade with them, others hatch them in ovens, and others attend on the young ones. They lay an iron plate on a brick hearth; on this they place a box full of fand $\mathrm{X} 4$ half 


\section{CHINESE HUSBANDPY.}

half a foot high, in which the eggs are put in rows: the box they cover with a fieve, over which they hang a mat. To heat them, they make ufe of the coals of a certain fort of wood, which burn flowly and uniformly: at firt they give them but little warmth, and increafe it gradually; and it becomes a ftrong heat by the time the eggs are hatched. Sometimes, when they increafe the heat too much, the young ducks are hatched too foon; and in that cafe they generally die in three or four days. The hatched young ones are fold to thofe who breed them up, and thefe try in the following manner whether they are hatched too foon or not: they take hold of the little ducks by the bill, and let their bodies hang down; if they fprawl and extend their feet and wings, they are hatched in due time; but if they have had too much heat, they hang without any ftruggling. The latter often live till they are put to the water (which is generally eight days after they are hatched), which turns them giddy; they get cramps ${ }^{1}$, throw themfelves on their backs, and die with convulfions. The owners then take them out

I Ducks hatched in England after Midfummer ufually get cramps, fprawl about in an odd manner, and throwing themfelves on their backs die of convulfions, 
of the water and dry them; becaufe they will fometimes recover: but they frequently die of fuch convulfions if they get wet again. When the tide goes off, fome little crawfifhes and crabs are gathered, boiled, and cut to pieces, and given to the young ducks by themfelves at firft, but afterwards mixed with fome boiled rice, and minced with herbs. When they are older they are fhifted into a larger fampane, which has a broad bottom of bamboo, with a gallery round, above the river, and a bridge declining towards the water. The young ducks get an old ftep-mother, who leads them when they are let down to graze by means of the bridge. The old duck is fo ufed to the fignal from the fampane in which they are affembled at night, that the haftens, half fwimming, half flying, to her lodgings. The Chinefe, as occafion ferves, removes his fampane to another place, where he finds more food for his ducks, and lets them out daily on the fhores among the rice-fields. One cannot fee without aftonifhment many fuch fampanes furrounded with greater and fmaller ducks: and it is very peculiar that when many fampanes feed their ducks in the fame place, and call them home at night, each knows how to find the right fampane. The Cbinese are al- 
ways employed in bringing up ducks, except in the three cold months; and though this bufinefs requires a deal of attendance, you feldom fee them employ any particular care, for as foon as the young ducks are a fortnight old, they are able to get their own fubfiftence.

The filk worms, which, confidering their ufe, ought to have a place among the fmaller animals, thould, together with their management, be defcribed: but as we find accounts of them in other Swedifh writings, I pafs them over, and fhall only mention that the Chinefe eat the aurelias with great appetite, after their filk has been wound off; and that they either boil them frefh, or dry them; the catty cofts eight or nine kandarins.

UP towards Chingchiu is faid to be a fpecies of very large filkworms, from which fo coarfe a filk is gathered, that at firft it looks like hemp; the inhabitants however make a fort of ftuff of it, which when new looks like unbleached linen, but by ufe and frequent wafhing acquires a glofs and better look. It feems that this filk will not take a dye, for 
BEASTS AND BIRDS. 3I5

they always wear it undyed, but it is faid to be ftrong beyond credibility, and is called Chingcbiu from the place it comes from.

\section{$\begin{array}{llllllllll}T & H & E & F & I & S & H & E & R & Y .\end{array}$}

The Taboa is a very long river, and wide at its mouth, and abounds more with fifh than any in this country; remarkable as the fhores of Clbina are for this commodity. It may perhaps be thought that the tide is a hindrance to any fifhery, efpecially in places which are inconvenient to be drawn with nets: however, they catch a mulritude with thofe implements. The moft common manner of catching fifhes is, they drive in on the fands at a diftance from the fhore, long poles or rather poits a fathom afunder; between thefe they place black coloured nets of ftrong yarn, into which the finh enter and are caught. This manner of catching filhes correfponds to ours of catching them with junkets placed in the river.

THEY have likewife a number of bafkets which are formed of bamboo and willow fticks, a fathom and a half long, and like our bafkets. They make ure of thefe when

the 
the water rifes more than ordinary ; they place them along the fhore, but leave openings on both ends of the row of bamboo bafkets, where they lie quite fill with their fampanes or boats, fo that the fifhes which fwim along the fhore may not be ftopped from entering them; but in the infide they meet with a row of bamboo bafkets, which are placed crofsways towards the thore, and ftop them from going back. As foon as the water again begins to run off, they fill up this fpace with the like balkets, the fpace of ground grows dry when the water has left it, and then they go down and gather up the filh. They likewife make ufe of a fwimming net faftened between two boats, with which they go up and down and catch the fhoals of fith coming in their way during the tide.

They likewife ufe great nets faftened between two bamboo poles, with which they filh both on their fea voyages and in the river.

THEY ufe worms and crabs as baits on their hooks, with which they catch eels and fmall fith. They likewife make ufe of long, low fampanes with white coloured boards on the fides; in thefe fampanes they keep a little fire 


\section{F I S H E R Y.}

at night, which makes the fifh, which purfue the fire, leap into the fampane. This kind of firhery is generally undertaken on account of a fpecies of filh called mullets, which leap in the dark towards the light of a fire.

BETWEEN the rocks and the fhore the fifhery is very great with nets and hooks: they catch a great quantity of fifh, and fell them falted or dried in the neighbouring towns and villages.

Among the many forts of fin there are fome like thofe known among us; namely carps, perches, and fea perches; but I cannot with certainty fay that they are the fame: thofe that are well known to me are eels, crabs, fhrimps, oyfters, mufcles, and lobfters: a very large fort of the latter is caught in plenty on the rocks of Macao. They do not only burn lime from the oyfter thells, but likewife make ufe of the largeft in their buildings inftead of bricks. 
,

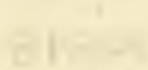

$316=09=$

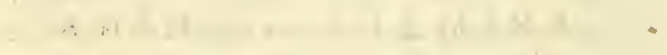




\title{
FAUNULA SINENSIS:
}

\author{
O R,
}

An ESSAY towards a CATALOGUE

๑ $\mathrm{F}$ TH E

A N I M A S OF CHINA. 


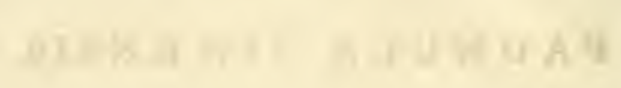

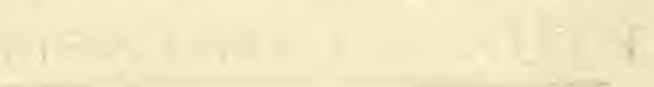

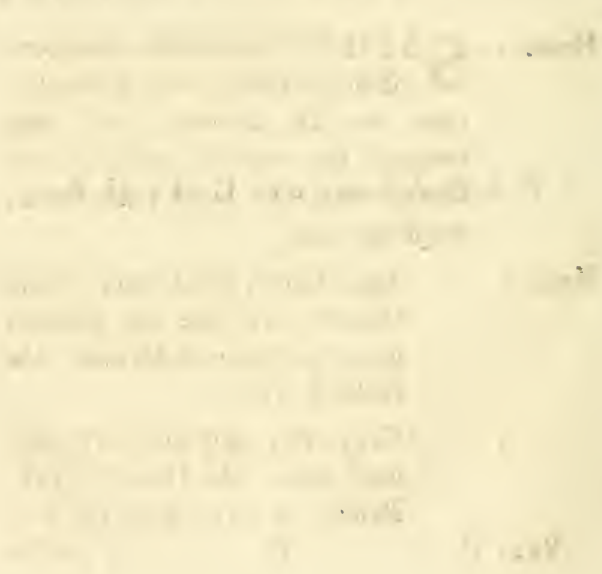




\section{$\left[\begin{array}{lll}32 & 1\end{array}\right]$}

\section{FAUNULA SINENSIS.}

M A M M A L I A. Quadrupedes.

I. $P_{R} I$ i $A$ T E s.

Homo I. C A PIENS monftrofus, macroce$N$ phalus, capite conico, Chinenfis: thus does Dr. Linnaus rank men amongft the animals, and calls the Chinefe with their large conic heads, monftrous men.

Simia I.

Ape. Great, black ones; their features are like the human. In the province of Haynan. Du Halde I. I 18.

2. Gray, very ugly and very common apes. Du Halde I. I 8. Briffon, p. 145 ? fpec. 18. with 
jellow hair, refemble dogs, and have a flrill cry. In the province of 2uang 2 . Du Halde I. I 2 I.

Veipertilio I. Bat. As big as hens, which the Chinefe eat, found in Shenfi. Du Halde I. 108.

\section{II. $B R \cup T A$.}

Elephas I. maximus. Elephant. In 2uang $\sqrt{\mathfrak{z}}$ and Tunnan. Du Halde II. 224.

Manis I. pentadactyla. In Formofa.

\section{FE R E.}

Canis I. familiaris. Common dog. Dog's flefh is eaten in Cbina. Du Halde I. 314 .

2. Lupus. Wolf.

Felis I. Tigris. Tiger. Very large and very common, called Lou-chu by the Chinefe. Du Halde II. $33^{6}$, and Muller's Collections for the Rufian Hiftory, vol. III. p. 587 .

2. Pardus. Leopard, called Poupi by the Cbinefe. Muller's Collections, rol. III. p. 587 .

3. Catus. 


\section{SI NE N S I S.}

3. Catus. Cat, eaten in Cbina. Du Halde I. 314.

$\beta$. angorenfis. Du Halde I. 65. In the province of Petcheli.

4. Animals in Shenfi refembling tigers, $D u$ Halde I. I 08 . perhaps it is a Tiger-cat which is found in the Tartarian defarts, is very fierce, about two feet long with out a tail; this I faw at Petetfburgh in her Majefty's elephant houfe.

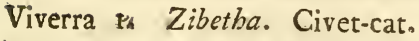

Muftela 1. Martes. Martin.

3. Zibellina. Sable, in the mountainous part of the Cbinese Tar. tary, to the north of the river Amur.

Urfus 1. Arctos. Bear.

2. Meles. Badger.

IV. G L I R E :

Hyftria I. criftaza. Porcupine.

Lepus 1. timidus. Hare.

2. Cuniculus. Rabbet.

Mus I. terreftris. Moufe.

2. Rattus. Rat.

Sciurus I. vulgaris. Squirrel.

$$
\mathrm{X}_{2} \text { V. PECORA. }
$$




\section{F A U.N U L A}

$$
\text { V. PECOR A. }
$$

Mofchus I. mofchiferus.

Cervus I. Alces. Elk.

2. Elapbus. Stag.

3. Dama. Fallow-deer.

4. Capreolus. Roe-buck.

5.

Stag no taller nor larger than a common dog; in Yannan. Du Halde I. 122.

Capra I. tatarica. Saïga. Yellow goats. Du Halde.

Ovis I. Aries laticaudata. Sheep.

Bos I. Bubalis. Buffalo.

2. Indicus.

VI. B E L I U X.

Equus I. Caballus. Horfe. Horfe-Herh is eaten in China. OJbeck.

Sus I. ScrofaChinenfis. Chinefe hogs are a variety.

Rhinoceros 1. unicornis. Du Halde I. 120. in the province of 2 uang $\sqrt{2}$. 


\section{S I NE N S I S.}

A V El S. Birds.

I. A C C I I I RES.

Falco. Falcons, excellent, but the fpecies not mentioned.

Lanius I. Schach.

2. jocofus. Sinenfibus Korv-kai-kon.

3. fauftus. Amœn. Acad.4. P. 241. among the Cbinenfia Lagerftros miana.

\section{P I c E.}

Pfittacus I. Alexandri.

2. criffatus. Cacatua.

3. green and red. Edw. 231 .

4. Galgulus. Parroquet. Calao $\mathrm{Si}$. nicè. Amœn. Acad. 4. p. 236.

Buceros I. bicornis.

Oriolus 1. Chinenfis. Linn. fyft. p, 160.

Cuculus I. Sinenfis. Linn. fyft. p. 17 I.

III. A N $S E R E S$.

Anas I. Cygnoides orientalis. Mufcory: goofe. Swan-goofe.

$$
\text { X 3. Anfer. }
$$


2. Anfer, Goofe.

3. Bofchas. Duck.

4. galericulata. Linn. fy ft. nat. 206 ,

Pelecanus I. Carbo. Corvorant.

2. Pifcator. Booby.

Sterna I. Stolida. Sea-fwallow.

IV. G R A L L

Scolopax 1, Rufticola. Woodcock. Fulica 1. Porphyrio.

$$
\text { V. G A I I I N A, }
$$

Pavo 1. criftatus. Peacock. Du Halde I.

$1_{13}$, is found in Quan-tong.

2. bicalcaratus.

Phafianus 1. Colcbicus. Pheafant.

2. Argus. Eaf-India pheafant.

3. pictus. Gold pheafant, by the Chinefe called Kinki, or golder bens. Du Halde I. 15.

4. nyclbemerus. Silver-pheafant.

Tetrio 1. Perdix. Partridge.

2. Chinenfis. The bill is pale-blue.

The head deep-brown edged with black, above the eye is a white line. The neck is dufky and moft elegantly marked with numerous minute circular fpots of white and 
S I N E N S I S.

and pale-brown. On the belly are larger ones of white only. The beginning of the back has others of pale-yellow. The reft of the back, wings, and tail, are pale-brown, fpotted here and there with minute dufky fpecks. Its legs are blue.

3. Coturnix. This and the foregoing fpecies are made ufe of, by the Cibinefe of quality, inftead of muffs.

\section{PAS SER S.}

Columba I. Sinica.

Sturnus 1. viridis. The green Stare. On the forehead and chin is a tuft of black and white feathers. Above the firft is a fpot of white: beyond the eye another. The whole upperpart of the body is green. On the fcapulars are two white fpots. The wings and tail are green, the outward webs of the firft are white; the fhafts of the wings and tail are alfo white. The underfide of the back, breaft, and belly, paleblue, the legs cinereous blue.

$$
\mathrm{X}_{4} 2 \text {. olivaceus. }
$$


2. olivaceus. The brown Stare, The bill is whitifh red. The eye lodged in a long ftripe of pale cœrulean. The whole body, the wings, and tail, light olive brown; on the belly faint, and tinged with yeliow. The legs are pale red, the tail is long.

Turcus 1. canorus. By the Cbinefe called Whom-mai.

2. Sinenfis. Linn. fylt. nat. p, 295 .

3. Chinefe black bird. Edw, 19.

S.oxia 1. Cardinalis. Cardinal bird. Amœn. Acad. 4. p. 242.

2. Dominicana, Amœn, Acad. 4 . p. 242 .

3. Maia.

4. flavicans. Ámœn. Acad, 4. P. 244.

5. oryzivora. Cock-paddy, or Ricebircl. A fort of crofs-bill, has a green and long forehead, and the crown is of pink colour. The hind part of the head, cheeks, the hind part of the neck, wings, breaft, and belly, are white. The chin, throat, and fore part of the neck, black, with

long 


\section{S I N E N S I S.}

long pendent feathers over the breaft, the tail is black, the legs green. This bird haunts the rice grounds, and lives on it.

6. Malacca.

7. Sanguini roftris, Amœn. Acad.4. p. 243 .

8. cyanea. Amœn. Acad. 4. p. 244. 9. fufca. ibid.

Tanagra I. militaris. Amœn. Acad.4 P. p.24I. Fringilla $x$. Melba,

2. Sinica,

3. Chinefe fparrows. Edw. 43 .

4. white breafted Chinefe fparrows. Edw. 355 .

An Fringilla? a fmall bird; the head, back, coverts of the wings are purple; the prime quill feathers and tail of a fine blue, the fecondary quill feathers are green; the whole underfide yellow, on the ears is a white fpot.

Anotber like the former, only the back and tail are purple.

Another with a green head, purple breaft, and the tail of the fame colour. 
A fourtb with a light green breaft. The head and lefs coverts are brown.

$A$ fifth has the head, back, and coverts of the wings of a fine deep brown. The tail is of the fame colour; the underfide of the body and the under coverts of the wings are of a fine crimfon.

Each of thefe five birds had the white fpot on the ears; but the head of the fourth was fo placed in the drawing, that one could not fee this fpot.

Hirundo 1. rufica. Chimney fwallow.

2. efculenta. The nefts of thefe birds are eaten as a dainty by the Cbinefe, and for that reafon are very dear. They are made of the fea-worms of the Mollufca clafs. For a further account, fee Kiempfer's Amon. Exotic. p. 833 , and Du Halde II. p. 20 I of the oftavo edition. 
A M P H I B I A. Amploibious Animals.

I. REI $I I I I A$.

Rana 1. Cbinenfis, palmis tetra dactylis fiffis, plantis hexadactylis, digito indice reliquis longiore. Ojbeck.

2. Bufo. Toad. Bradley's Works of Nat. p. 165, fays toads are eaten in China, and are found in the middle of ftones and in oaktrees.

Lacerta I. Cbinenfis, cinerea, cauda ancipiti, corpore paulo longiore, pedibus pentadactylis omribus unguiculatis. Ojbeck.

\section{N A N T E s.}

Lophius 1, bifrio. Amœn. Acad. 4. p. 246. Baliftes I. Monoceros.

2. Vetula. Amœn. Acad. 4. p. 247.

3. fcriptus. OJbeck.

4. nigro punctatus. Oßbeck,

5. Sinenfis. Ofbeck.

Tetrodon I. hijpidus. Amœn. acad. 4. p. 247. ocellatus, called de Opblafer by the Dutch. A decoction of this fifh 
firh is made ufe of by the Chinefe and Japanese as a poifon, and a branch of the Illicium anifatum or Badian-tree boiled, with this decoction, makes it ftill more poifonous. vid. Keempf. Amœn. Exot. p. 880, 881 .

P I S C I S. Fifh. I. $\mathcal{P} O O \quad \mathrm{E} S$.

Trichiurus 1. Lepturus. Linn. fyft. p. 429,

II. THORACI C I.

Gobius 1. niger.

2. Eleotris.

3. anguillaris. Linn. fyft. p. 450.

4. pectiniroftris.

Chætodon 1. pinnatus. Amœn.Acad. 4. p.249.

2. argenteus. ibid.

Sparus 1. nobilis. Mandarin fifh. Ojbeck.

2. Chinen/is. Leffer Mandarin fifh. By the Cbinefe called Kya-yo. ojbeck.

Labrus I. opcrcularis. Amon. Acad. 4. p. 248.

2. Chinenfis. Linn. fygt. p. 479 . Scomber I. Trachurus. Horfe Mackarel or Scad. Amcen. Acad. 4. p. 249. 


\section{S I NENS I S.}

III. A B D O I N ALE S.

Clupea I. Tbriffa.

2. Myftus.

3. 'Sinenfis. Linn. fyft. p. 525 .

4. lanatus. Amœn. Acad. vii, 502.

Cyprinus 1. auratus. Gold firh.

2. Cantonenfis. Oßbeck. very probably a variety of the Cyprinus Griflagine of Linneus, as $\mathrm{Mr}$. ofbeck himfelf feems to intimate.

I $N$ S E C $\mathrm{C}$ T A. Infects.

I. COLEOPTERA.

Scarabæus I. Molofus. Linn. fyft. p. 543 . This fpecies is made ufe of in the Chinefe apothecaries thops.

Caflida I. cinerea. 2. laticollis. Linn. fyft. nat. p. 549 .

2. nigra, oblonga, fafciis duabus

- tranfverfis teftaceis, punctis quatuor ad bafin. Ojbeck.

Coccinella I. Septem punctata. 2. quadri pufulata.

Bruchus I. pectinicornis. Linn. fyft. p.605. Lampyris 
Lampyris I. Chinenfis. Linn. fytt. p. 645. \& Ojoeck.

Bupreftis I. gigantea.

Meloe ð. Cichorii. Muf. Lud. Ulr. 103. \& Amœn. Acad. 6. p. 137.

II. HEMIPTER A.

Blatta 1. Orientalis. Cock roaches.

Mantis $\mathrm{s}$ pectinicornis. Linn. fyft. nat. p. 690.

Fulgora $x$. Candelaria. Chinefe lanthornfly.

Thrips 1. paradoxa. Linn. fyft. p. 743, \& Amœn. Acad. 6.p.401 n. 48.

\section{I E P I D OPTERA.}

Papilio I. Paris.

2. Helenus.

3. Troilus.

4. Deiphobus.

5. Pammon.

6. Memnon. Linn.

7. Agenor. Linn.

8. Agamemnon.

9. Pbiloctetes.

iо. Demoleus.

81. Mneme. Amœn. Acad. 6. p. 403 . n. 54 . 


\section{S I N E N S I S.}

12. Thallo.

I3. Brafjece. Linn.

14. Napi. This fpecies is twice as big as the European variety.

15. Pyrene. Linn:

16. Euippe.

17. Glaucippe. Linn.

18. Hecabe. Mur. Lud. Ulr. 249.

19. Trite.

20. Pyrantbe. Lina.

21. Midamus.

22. Plexippus.

23. Chrysippus.

24. Mineus. Linn.

25. Almena.

26. Aonis.

27. Oenone. Muf. L. U. 274, 275 .

28. Lemonias. Mur. L. U. 277 .

29. Orithya.

3०. C. aureum.

31. Leucotboe.

32. Jimilis.

33. affimilis. Muf. L. U. p. 300.

34. diffimilis.

35. Niphe. Linn. P. Hypzrbius Amœn。

Acad. 6. p. 408. n. 75 .

36. Augias. Amcen. Acad. p. 410.

n. 8 o. 
37. Lintingenfis, fubtus pallide luteus nebulofus, fupra nigricans, luteo imprægnatus. Ofbeck.

38. argyrius.

39. Pyrene.

Sphinx 1. Atropos.

2. Auxo. Linn.

3. Procellus.

Phalæna I. Atlas.

2. Mori. The larva of this Moth is the filkworm.

3. lectrix. Linn.

4. feticornis, fpirilinguis alis planis, fuperioribus cærulefcentibus, margine exteriore duabus maculis luteis. Ofbeck.

5. nigrella.

6. altica.

7. bicincta.

8. macrops.

IV. NEUROPTERA.

Libellula. 1. Chinenfis. Ojoeck.

2. fufca, capitis lateribus viridibus. Ofoeck. 
V. HYMENOPTERA.

$A$ pis I. lievis, flaro, fulvoque varia, abdomine lineis, tranfverfis undatis nigris. Ofbeck. The Clbinefe call them Drong. fong.

VI. D I P T E R A.

Culex Is pipicns. MIofquitoe.

VII. $A P T E R A$ 。

Termes I. fatalc. Linn.

P'ediculus I. bumanus. Loufe.

Aranea 1. ocellata. Iinn.

Cancer 1. Grapfus. Amoen. Acad. 4. P. $=52$.

t. 3. fig. Io.

2. Chinentis. Ofock.

3. Oryzx. Ofeeck.

Scolopendra I. morfitans.

Julus 1. ovalis. Amœn. Acad. $4 \cdot$ p. $253^{\circ}$

2. crafus. ibid.

3. fufcus. ibid.

V E P R E S. Worms.

1. $M O L \perp$ U S $C$ A.

Nereis 1. carulca. Amœn.Acad.4. 1. 254.

Holothuria I. Priapus. Amcn. Acad.4. p. 255 .

VOL. II. 
Medufa I. Porpita. Amœn. Acad.4. P. 255 . t. 3 . f. $7,8,9$.

Afterias I, pectinata. Amœn.Acad.4.p. 256. 2. Luna. ibid.

II. T E S T A C E A.

Chiton I. punctatus. Amœn. Acad.4. p. 256. Lepas I. Mitella. Linn. Balanus Cbincn fis friatus. Petiver. Gaz. t. I. f. 10. Voluta I. monilis. Linn.

Oftrea r. Chinenfis. Ofbeck. The Clainefe call it Hao.

\section{L I $\mathrm{T}$ н $о$ Р $\mathrm{P}$ Ү $\mathrm{T} \mathrm{A}$.}

Maàrepora I. polygama. Amœn. Acad.4.p.258. Corallium ' I. Chinenfe. Amon. Acad. 4. p. 258. tab. 3. f. Ir. feems to be the Madrepora polymorpha of Linneus.

\section{Z $O O P$ H Y T A.}

Sertularia I. confervæ formis. Ofock. Vorticella I. conglonerata. Linn. Hydra conglomerata. Amcen. Acad. 4. p. 257. t. 3. fig. 1 .

Pennatula I. phosphorea. Amœn. Acad. 4. p: 256.

2. mirabilis. Amœn. Acad.4.p. 256 . 3. Sagitta. ibid, 


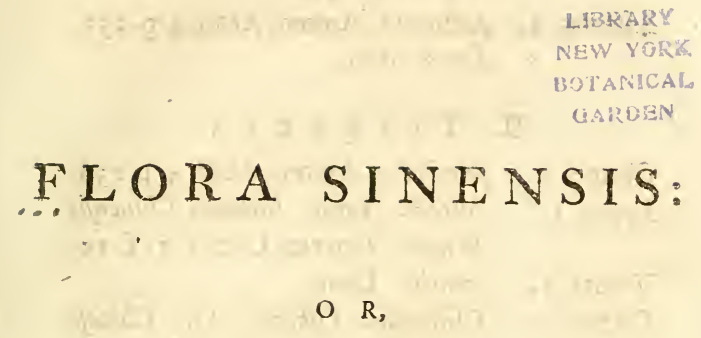

An ESSAY towards a CATALOGUE

$$
\text { O F }
$$

C. I I E S E PLA N T S,

$$
\text { Z. } 2
$$





\section{[ $34 \mathrm{I}]$}

\section{F L O R A S I N E N IS.}

$\begin{array}{lllllllll}M & \mathrm{O} & \mathrm{N} & \mathrm{A} & \mathrm{N} & \mathrm{D} & \mathrm{R} & \mathrm{I} & \mathrm{A} .\end{array}$

$M O N O G Y N I A$.

Cann a r. Indica. Indian cane.

Maranta I. Galanga.

Curcuma I. Chinenfis. Ofbeck.

$$
\begin{aligned}
& \text { D I A } \\
& \text { M }
\end{aligned}
$$

Nyctanthes I. birfuta.

2. Orientalis. Ofbeck.

Jufticia 1. Cloinenfis. Linn. fyft. nat. tom.

$$
\text { 2. p. } 60 .
$$

2. purpurca.

Gratiola I. Virginianoides. Ofbeck. Probably a variety of the Gratiola virginiana. Linn.

Utricularia I. bifida. fee tab. iii. fig. 2.

$$
\mathrm{Z}_{3}
$$

Verbena 
Verbena I. nodiflora.

Monarda I. Chinenfis. Ojoeck.

$$
\text { T R I G Y N I A. }
$$

Piper 1. Betle.

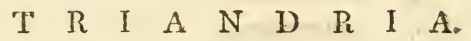

$$
\text { M-O N O G Y N I A. }
$$

Valeriana I. Cbinenjis.

Tamarindus 1. Indica. the Clbinefe call it Tchampaboo.

Ixia I. Chbinenflis. Linn. fpec. pl.p.52.

Commelina $\mathrm{I}$. communis.

2. Chinenfis. Ofock. Perhaps it is the fame with the Commelina nudiflora. Linn.

Cyperus i. baspan.

$$
\begin{aligned}
& \text { 2. Iria. } \\
& \text { 3. odoratus. } \\
& \text { 4. glomeratus. }
\end{aligned}
$$

Scirpus $\mathbf{I}$.

Chinenfis. Ofbcck.

Nardus I. ciliaris.

2. articulata. Ojbeck.

$$
\text { D I G Y N I A. }
$$

Saccharum I. officinarum, by the Clbincfe called Ki-ce. 


\section{S I N E N S I S.}

2. pluviatile. Ofocck. Qu. Is nor this a variety of the former?

Panicum I. alopecurodeum.

2. glaucum.

3. Crus galli.

4. brevifolium.

5. arborefcens.

6. patens.

7. diffectum. OJueck. Perhaps the P. dimidiatum. Linn.

Alopecurus I. Hordeiformis. Agroftis 1. Indica.

Aira I. feminibus hirfutis, ariftis terminalibus, flore longioribus. Ofbeck.

Poa 1. angufifolia,

2. Malabarica.

3. Cbinenfis.

4. tenella.

Briza I. elegans, fpicis oblongis, valvulis carinatis. Ofbeck.

Cynofurus I. Agyptius.

Arundo I. Bambos, the Bamboo-reed.

$$
T R I G Y N \text { I A. }
$$

Eriocaulon 1. Sexangulare.

Mollugo I. pentaplyylla.

$$
\mathrm{Z}_{4}
$$


$344=$ F $\quad$ L $\quad$ O $\quad$ R A

\section{T. $E$ T $R$ A N D R I A. \\ M O N O G Y N I A.}

Hedyotis I. berbacea.

Spermacoce 1. verticillata.

lxora I. coccinea, by the Cbinefe called Kian-long-fare.

Plantago I. Afiatica. Linn. fpec. pl.p. 163.

Oldenlandia r. umbellata.

Ammania 1. baccifcra.

Trapa I. natans, by the Clbincfe called Ling-komn or Leng-ka.

$$
\begin{aligned}
& \text { P E N T A N D R I A. } \\
& \text { M O N G Y N I A. }
\end{aligned}
$$

Convolvulus I. bederaceus.

2. Butatas, called Fauciy by the Cloincfe.

3. biforus. Linn. Sp. pl.p. 1668.

4. reptans.

5. Birtus.

6. Pes Capra.

Ipomea I.

Nauclea I.

Morinda 1 .

2.
Quamoclit.

crientalis.

unibellata, or Pa-cock-faw of the Cloinefe.

citrifclia.

Muffrnda 


\section{S I N E N S I S.}

Niuffxnda I. frondofa.

Mirabilis I. odorata, Ofbeck. Perhaps M. dichotoma. Linn.

Datura 1. ferox. Linn. Spec. pl. p. 255.

Nicotiana 1. fruticofa. Linn. fp. pl.p. 258.

Solanum 1. diphyllum.

2. Ettbiopicum. Linn. fp. pl. p. 265 .

3. Indicum.

Capficum I. frutefcens.

Lycium I. barbarum.

Rhamnus 1. lineatus, fee tab. vii.

2. anoplia.

3. Thea, Ofocck. The leaves of this thrub are made ufe of by the poorer Cbinefe, inftead of tea.

Mangifera $\mathrm{I}$. indica. The Cbinefe call the fruit Luai-mao.

Achyranthes I. afpera.

2. lappacea.

3. Chinenfis. Ofbeck.

Celofia I. argentca.

$$
\text { 2. criftata. }
$$

Gardenia fiorida, or the Cape Jarmine. Calyx monophyllotis, quinquangular, divided in five fections, Corolla monopetalous, has a long cylindrical tube, the fections of 


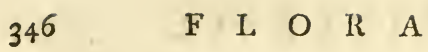

the flower leaves divided into five ovated fegments. Antherce feated within the tube; the Piffil is below the flower, the flower ftem filiform, divided, and clavated; Stigma is bilobous, ovated, obtufe and great.

Seed Veffel egg-thaped, ribbed from the defcending wings of the flowercup, and within divided into two cells by a thin membranaceous partition.

Secds numerous, compreffed, and furrounded with a mucilaginous fubftance.

Arbufcula Sinenfis, myrti majoris folio, vafculo feminali hexagono, ad fingulos angulos alis foliaceis munito, qux porrectr vafculi coronam efformant. Umki Sinenfibus dicta. Plukn. Amalth. p. 29.

Umky alias Umuy; cujus fructum ad colorem efcarlatinum tingendum infervit; florem fert rofaceum, album, hexapetalum. Plukn. Amalth. p. 212. tab. $44^{8}$. fig. 4. Frutex cynofbati fruću alato, tinctorio, barbulis 


\section{S I NENSIS.}

barbulis longioribus coronato. Petiv. Muf. p. 498. Ray. Hif. III. p. 233 . Jafminum foliis lanceolatis oppofitis integerrimis, calycibus acutioribus. Mill. Dict. n. 7. Mill. fig. I 80. Jafminum? ramo unifloro pleno, petalis coriaceis. Ehret. tab. 15. E. N. C. 176I. P. 333 .

Gardenia Jafminoides. Ellis Phil. Tranf. i 76c. p. 929. tab. 23. Gardenia Jafminoides. Solander Phil. Tranf. 1762. p. 654. tab. 20. The variety of this plant with double flowers was brought from the Cape of Good Hope in the year 1744, by Captain Hutcbenfon, and prefented by him to Richard Warner, Efq. of Woodford Row, Effex. Mr. Ellis procured for Mr. Fames Gordon fome fhoots, which turned very beneficial to Mr. Gordon, for he by his ingenuity brought three fhoots to grow, and afterwards multiplied them fo much that they are now at prefent in all the gardens of England. The plant with fingle fowers was found by Mr. Cunningham in 
Cbina, and in the Eaft Indies. Some gentlemen have lately feen this fhrub on the coaft of Coromandcl. The Clinese call it Umki, and dye with the feeds fcarlet, it may perhaps, if properly enquired into, turn out a great improvement in the art of dying, and therefore deferve the attention of the commercial part of the public, and become an article of importance in commerce, if planted in the Englifh colonies in North America.

Nerium I. Oleandcr.

\section{I G Y N I A.}

Periploca 1. Graca.

Chenopodium I. Scoparia.

Gomphrena I. glohofa.

Hydrocotyle r. Chinenfis. Linn. fpec. pl. p. 339 .

Athamanta 1. Cbinen/is. Linn. fp.pl.p.353. Siun 1. fisarum. Linn. fp.pl.p. 361 .

2. Ninfl. ibid.

$$
\text { T R I G Y N I A. }
$$

Rhus I. Gavanicum, by the Clbincfe called Tailas.

2. Chinenfe. 
2. Chinenfe. Ofoeck. by the Clbinefe called Mon-kbi.

Sambucus I. nigra.

Bafelia 1. rubra. The Clbinefe call it Tang. Soy.

2. alba. Linn. fp. pl. 390 .

$$
\text { T E T R A G Y N I A. }
$$

Evolvulus 1. alfinoides.

$$
\text { P E N T A G Y N I A. }
$$

Aralia I. Chinenfis.

$$
\begin{aligned}
& \mathrm{H} E \mathrm{E} A \mathrm{~A} \text { D R I A. } \\
& M \circ N O G \quad \mathrm{~N} \text { I. A. }
\end{aligned}
$$

Narciffus I. Tazetta.

Dracæna I. ferrea; in the Cbineje lan.

Convallaria I. Cbinenfis, foliis linearibus, corollis fexpartitis. Ofoeck.

Hemerocallis I. fulva. Linn. fp. pl. 462.

Loranthus I. fourrula. Linn. fp. pl. 472.

$$
\text { D I G Y N I A. }
$$

Oryza I. fativa. Rice. The Cbinefe call it Vo. $a$ whilft it is growing, and $V_{0}$ - 
. Kock before it is ground. The raw groats they call Mai, but when boiled they give it the name of Fann.

\section{O C C T A N D R I A. \\ $M \circ N O G Y N I A$.}

Orbeckia I. Cbinenfis; by the Clinefe called Fonm-boeong-lo-aw. See tab. ii. fig. $1,2,3$.

Daphne I. Indica.

Backea I. frutefcens; called Tiong-maru by the Cbincfe. See tab. i.

$$
\text { T R I G Y N I A. }
$$

Polygonum $\mathrm{I}$. barbatum. Fa-yong-moea in the Chinefe language.

2. orientale. In the Chinefe language $Y_{\text {ong-moca. }}$

3. Chinenfe.

\section{E N N E A N D R I A. \\ $M \circ N O G$ Y N I A.}

Laurus 1. Camphora. The Chinefe call the tree Tiong-fio, but the Camphire extracted from it they call Tiong. No-o.

Carfytha 1. filiformis. 


\section{SI NEN S I S.}

\section{T R I G Y N I A.}

Rheum I. undulatum. Linn. fpec. pl. p. 53I.

2. palnatum. ibid.

3. compactum. ibid.

\section{E C A N D, R I A. \\ $M O N O G \quad Y$ N I A.}

Caffia 1. Sopbera.

2. procumbens.

Juflixa I. repens.

$$
\text { D I G Y N I A. }
$$

Dianthus I. Clbinenfis.

$$
\text { P E N T A-G Y N I A. }
$$

Averrhoa I. Bilimbi, by the Cbinefe called Sam-nim.

$$
\begin{gathered}
\text { DO D F C A D R I A. } \\
\text { M ONOG Y I A. }
\end{gathered}
$$

Lythrum I. fruticofum. Linn. fp. pl. p. 64 I.

$$
\text { T R I G Y N I A. }
$$

Euphorbia I. neriifolia.

$O$ C T A- 

O C $\quad$ T A G Y N I A.

Illicium 1. anifatum. Linn. fpec. plant. pag. 664. The fruit of this tree is probably the Badian or StarAnis; and a branch of this tree, boiled with the Tetrodon ocellatus, makes the broth of it ftill more poifonous.

Pfidium I. Guayava, Ofbeck. Probably P. pyriferum. Linn.

\section{C O S A N D R I A. $P \circ$ O L $\quad Y \quad G \quad Y \quad N \quad I$ A.}

Rofa I. Indica.

Rubus r. parvifolius.

$$
\begin{aligned}
& \text { P O L Y A N D R I A. } \\
& M \circ N O C \text { Y N I A. }
\end{aligned}
$$

Nymphara I. Nelumbo.

Lagerntromia r. Indica. Isjin-kin of the Cbinefe.

Thea I. bobea, with fix petals. The leares ftand alternately on the Aalk, are elliptical, fmooth, foncwhat obtufe, ana ferrated 


\section{SI NE N S I S.}

or fawed in fucis a manner as to make the outftanding corners obtufe. The footftalks are flort, round below, and gibbose. It bas no ftipulx. Linn. fyft. nat. tom. ii. p. 365 .

z. viridis, with nine petals, Linn. The variety of tea which is called green tea with nine pétals, is entumerated by Dr. Limnaus only upon the authority of Dr. Hill's Exotics, tab. 22. but it is quite incredible that green tea hould be a thrub fo different from the bobea tea, that it fhould differ in the petals: of which the latter fpecies, according to Krempher, Amœn. P. 6 I I, has fix, which he himfelf faw in Japan: and what is more remarkable, Ficmpher fays the green colour of tea depends only upon the manner and care taken of it in drying. For fome roaft the leaves in a large iron pan two or three times only, which fudden roafting makes them brown, and tinges the infufion with the fame colour ; but on the other hand others preferve that vivid green in the 
leaves (and confequently in the infufion) by a flower roafting; and repeat the operation five, fix, and even feven times. Between each roafting the tea-leaves are rolled in one direction on a table covered with a bamboo or rufh-mat: but never is this operation performed backwards and forwards. The pan muft be fo hot, that by putting a freh leaf in it, it may make a hiffing noife from the expelled juice. The leaves are continually ftirred by mens hands, till their heat grows intolerable; and then they are taken out with a wooden rake, and rolled as above on mats. The Chinefe, to take off the narcotic power of the tea-leaves of the firft collection, foak them for half a minute in boiling water. In curing the beft forts of tea, the pan is wanhed, and cleaned with boiling water after each roafting.: This is however true, that there are many varieties of tea, differing one from another in the fhape and quality of the leaves: thus the Iea-Ankai has oblong leaves, the 
Tea-Soatchoun has lanceolated leaves and the tea Linkifom has hoary or rough leaves.

Captain Eckeberg brought a little tea-ihrub, the third of Catober $176_{3}$, to Srueden; which is the firft that ever came to Europe, for all forts of trees die on the voyage: but the way to obtain them is to put the frem feeds into pots in Cbina, a litthe before the thip fails. And as a tea tree, according to Kamplser's account, attains its full growth of about fix feet high in feven years, it is probable that Dr. Linnceus's tree is now in full vigour. He intends to multiply this fort of tree, and to expofe it then to the open air; as the tea-fhrub grows as high as the latitude of Pekin in the open air, where the winters are far more fevere than in England and in the fouth of Sweden. It is therefore highly probable that this attempt will fucceed: and fo it would in England, but not in the American colo. nies, for want of fuch a quantity of

$$
\mathrm{Al}_{2}
$$
hands 


\section{$\begin{array}{llllll}356 & \text { F } & \text { L } & \text { O } & \text { R } & \text { A }\end{array}$}

hands as the cultivation and preparation of tea require.

Clematis I. Chincnfis. Ofocck; it is perhaps a variety of the Clematis Vital. $b a$, Linn.

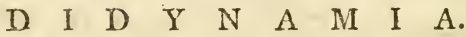
G Y M N OS P E R M I A.

Hyffopus I. Lopbantbus. Linn. fpec. plant. pag. 796.

Leonurus I. Sibiricus. Linn. fpec. plantar. pag. 818.

Ocymum I. gratifimum. Scutellaria ז. Indica.

$$
\text { A NGIOSPERMIA. }
$$

Gerardia I. glutinofa. See tab. ix.

Torenia 1. Afiatica.

2. B. glabra. Ofbeck.

Capraria I. cruftacea. Linn. fyft. nat. tom. ii. p. 419. \& Mantiffa, p. 87 .

Buchnera r. Afratica. Linn. fpec. plant. 879. Ruellia I. crippa.

2. ringens.

3. anipoda.

Barleria 


\section{S I NE N S I S.}

Barleria I. criftata, in the Clbinefe language Ab-keyfaw. See tab. viii.,

Volckameria I. inermis.

Clerodendrum I. fortunatum, by the Chi. nefe called Far-tag-nong. See tab. xi.

Vitex I. Negundo.

Columnea 1. Chinenfis. Ofoeck. By the Cbinefe it is called Pange-ka.

\section{TE T R A D N A M A. S I L I Q U O S A.}

Brafica 1. Chinenfis, or the Fai-lann of the Chinefe.

2. violacea. Linn. fpec. plant. 932.

Sinapis I. juncea. Linn. fpec. pl. 934.

2. Orientalis:

3. Chinenfis. Linn. fyft. nat. tom. ii. pag. 445, \& Mantiff. plantar. pag. 95 .

Raphanus I. fativus. Linn. fpec. pl. 935.
A 33
MONA- 
MON A DELPHIA.

$$
\text { P.O L Y A N D R:I A: }
$$

Sida 1. Spingfa.

Urena 1. lobata.

2. procumbens.

3. Chinenfis, caule erecto, floribus majuículis. Ofbeck.

Goffypium 1. berbaceum, or the Chinefe Minfu.

Hibif̣cus I. mutabilis.

2. ficulneus.

Camellia I, faponica, by the Cbinefe called Fo-kaï.

D I A D E L P H I A.

O C T A N D R I A.

Polygala I. Cbinen/is. Linn. fpec. pl. 989. 2. ciliatn.

DE C A N D R I A,

Abrus 1. precatorius:

Crotalaria I. Chinenfis. Linn. fpec. pl. 1003: 2 juncea? 


\section{SINEN SIS.}

2. juncea.

3. Sefliffora, Linn. fp. pl. 1004 .

Phafeolus I. radiatus. Linn. fp. pl. 1018.

Dolichos I. Sinenfis, by the Cbinefe called Ta-o.

Hedyfarum I. maculatum,

2. Ayracifolium.

3. Gangeticum.

4. triquetrum, by the Cbine fe call. ed Ka-fong-Soe,

5. pulchellum.

6. biarticulatum.

7. heterocarpon.

8. triflorum.

9. lagopodiodes.

Indigofera 1. tinctoria. The Chinefe call it Tong-ann or Vare.

Aftragalus 1. Chinenfis. Linn. fpec. plant. 1066.

2. Sinicus. Linn. fyft. nat.tom. ii. pag. 499. \& Mantif. p. 103.

A2 4 POLYA. 


\section{POL Y A D L P H I \\ I C O $\$ \triangle N$ P R I A:}

Citrus I, Medica.

2. Aurantium.

3. decumanus.

P O L Y A N D R I A.

Hypericuin I. monagymm. Linn. fpec. pl. I 10.7 .

2. Chinenfe. Ofbeck.

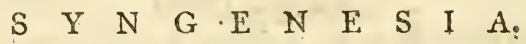
POLYGAMIA EUALIS.

Cacalia I. foncbifolia Linn, fpec. pl. I 69 :

2. incana.

Ethulia I. tomentofa. Linn. fyft. nat, tom. ii, 536. \& Mantiff. pl. pag. I 10.

POLYGAMIA SUPERTLA.

Artemifia I. vulgaris, by the Chinefe called Gnaï.

2. Cbinenfis. Linn. fp. pl. I 190,

3. minima. ibid.

Farpefium I: abrotanoider: See tab. x.

Baccharis 


\section{SINENSIS.}

Baccharis 'r. Indica, or the Kiate-gnaï of the Chinefe.

Conyza 1. Chinenfis.

2. birfuta. The Clininefe call this plant Vreelatfoy, or Kang-ganfaw.

Senecio I. divaricatus. After 1. Indicus.

2. Chinenfis. Chinefe After. Linn. fpec. pl. 1232.

Solidago I. Chinenfis, caule procumbente, ramis alternis, foliis radicalibus linearibus. Ofbeck.

Chryfanthemum I. Indicum, by the Clbinefe called Kock-faw.

Sigenbeckia I. Orientalis, The Cbinefe name is Fibimag.

Verbefina 1. Chinenfis, by the Chinefe called Kaling-faw.

2. proftrata.

3. colendulacea.

M O N O G A M I A.

Lobelia 1. zeylanica.

Impatiens I. Cbinenfis.

2. balfamina. 


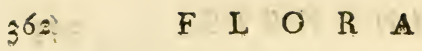

\section{$\begin{array}{llllllllll}G & Y & N & A & N & D & R & I & A\end{array}$ D I A N D R I A.}

Epidendrum I. cnfffolium.

$$
\text { DE C A N D R I A. }
$$

Helizeres I. angufifolia, by the Cbinefe called Kay-maw. See tab. v.

\section{O N O E C I A. TRIA N D R I A.}

Phyllanthus I. Niruri.

$$
\text { TE T R A N D R I A , }
$$

Urtica I. nivia.

Morus x. alba.

$$
\text { P EN T A N D R I A. }
$$

Xanthium 1. Orientale. Linn. fp. pl. 1400. Amaranthus I. triftis, called In-foy by the Chinefe.

2. cruentus. Linn. fp. pl. 1406. 


\section{SINE N S I S. \\ P O}

Sagittaria 1. trifolia. Linn. fp. pl. 1410.

2. Sagittifolia, called Succoyee-fare.

M O N A D E I. P H I A.

Thuya 1 . orientalis.

Croton I. Sebiferum, by the Cbinefe called O-ka-o.

S Y N G E N E S I A.

Trichofanthes 1. Anguina. Linn. fp.pl, 1432. Cucurbita 1. lagenaria, by the Chinele called $P$ o-0. Parents hang the fruit of this plant to their children's necks, to prevent their being drowned.

2. Cbinenfis, Ojbeck.

Cucumis 1. acutangulus. Linn. fpec. pl. 1436 .

Bryonia 1. cordifolia.

$$
\text { G Y N A N D R I A . }
$$

Andrachne 1. fruticofa. 
$3^{64}$

$\begin{array}{llllll}F & L & O & R & A\end{array}$

\section{.D I O E E C I A. \\ PENTA N D R I A.}

Zanthoxylum I. trifoliatum, called Lack-fazw by the Cloinefe.

H E $\quad$ X A N

Smilax I. faffaparilla.

2. China, is by the Clbinefe called Long-fan-tao.

Diofcorea 1. alata. Yams. Their Chinefe name is Idai-fio; but Captain $E_{c k e b e r g}$ fays, the Cbinefe call them Oo-taw.

\section{P O L Y G A M I.A. \\ 'M O N O E C'I A.}

Mufa I. paradifiaca. Plantain-tree. Is called Tfey by the Chinefe.

- $\beta$. Cliffortiana. Linn. fp. pl. 1477.

Andropogon r. Scbonantbus.

2. Ifchamum.

3. fafciculatum,

Holcus 


\section{S I N E N S I S.}

Hoicus I. latifolius.

Apluda I. mutica.

Ifchæmum r. arifatum.

Mimofa I. Chinenfis, inermis, ftipulis foliolo longe majoribus, femicordatis. Ojbeck.

Panax I. quinquefolium. Ginfeng. By the Chinefe called fanfom, or Janfam.

$$
\text { T R IOE C I A. }
$$

Ficus I. Indica. Banian-tree.

2. pumila. Linn. fpec. pl. 1515.

C B Y P TOGA M IA. F I L I C C E S.

Onoclea r. fenfibilis.

Ophiogloffum I. fcandens, by the Clbinefe called Krayin-sé.

Acroftichum I.' princtatum. Linn. fpec. pl. 1524 .

2. dicbotomum. ibid.

5

Pteris 
Pteris 1.

2.

vittata. See tab. iv.

Semipinnata, by the Clinefe called Kalao. See tab. iii. fig. I.

Blechnum 1. Orientalis.

Polypodium I. varium.

2. crifatum.

3. Barometz.

Adiantum 1. flabellulatum, by the Clbinefe called Siagmaoquang.

2. cbufanum. Linn. fp.pl.1558。

Trichomanes I. Cbinenfe. See tab. vi.

$$
\text { M U S } \quad \text { c I. }
$$

Lycopodium I. nudum.

2. cernuum.

3. varium. Ojbeck.

\section{A I G E.}

Jungermannia I. Chinenfis. Ofbeck. See Dill. Mufc. t. lxix. fig. 4 .

Lichen I. criftatus.

2. Chinenfis. Ofbeck.
3. Euphorbire, foliaceus, pul-
verulentus. Ofbeck.

Fucus 


\section{S I N E N S I S.}

Fucus I. Tendo. Linn. fp. pl. 1631 . Byffus I. Flos Aqua.

$$
\text { F U N G I. }
$$

Agaricus I. Chinenfis. OJbeck. Confer Fungus Kæmph. Amœn. $83^{2}$.

Boletus I. Favus. Linn. fp. pl, I645. 



\section{N D E X.}

The common Figures denote the Page; the Roman Numerals the Volume: where no Roman Numetals are puts the firft Volume is meant.

A.

$A^{B R U S}$ precatorius,

2 Acanthus ilicifolius;

Acanziles or Alcachofas, fee Cynara Scolymiss.

Achyranthes afpera,

\section{Chinenfis,}

lappacea,

Acrofs the way, an Ifle near Java, fo called,

$3^{84}$

138

Adelphozion,

Adiantum flabellulatum,

Adonis annua,

Agaricus Chinenfis,

Agave fimericana,

Agroftis Indica,

Aira feminibus hirfutis;

Albatros, fee Diomedea exulans.

336

329

ibid.

133

123

II. 7

73

356

52

346

354 Albula Cbinenfis,

VoL. II.

$\mathrm{B} \mathrm{b}$

Alliam 


\section{$\begin{array}{lllll}I & N & D & E & X\end{array}$}

Allium fubbirfutum,

Almanacks, Chinefe,

Alsine media,

Alum,

American alö̈, fee Agave Americanco.

Ammania baccifera,

Ammi Hifpanicum,

wAmomum Zerumbet,

Anagallis latifolia,

monelli,

Anas Chinenjis,

- nigra,

Anchufa angafifolia, officinalis, Andracbne fruticofa, Andropogon bicorne?

- faficulatumy

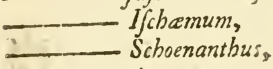
346 ibid. ibid.

Anemane palmata,

Anctburi foxiculum,

Angeri point, on Java,

Anthemis valentina, Antboxantbum odioratum

Antbyliis tetrapbylla, Antirrbinum arvenfe,

Apis lavis, flavo fulvoque varia,

Apluda mutica, 


\section{N D E E}

Architecture, Indian,

Areca Cathecu,

Arenaria rubra,

Arifida adfcenfionis,

Arifolocbia rotunda,

Armenians, at Suratte;

Aromas, fee Mitrofa Farnefsarido

11. 197

257

$7 \dot{4}$

II. 98

55

II. 202

Arrack,

Artemifia vuigaris,

Artichokes, fee Cynara Scolymis.

316

394

Arum arifarim,

maculatum,

Arundo Bambos,

Donax,

Afcenfion Ifland; in the fitlantic Ocea's, Afclepias giganteä,

Afia, preferved Bamboo soots,

Afparagus actitifolius,

apbyllus,
falcatus,
oficinalis,
Afphodelus fiflulofis,
ramofus,

Afplenium nidus,

Affes, common in Spaiti,

दे

56

276

II. 55

140

310

55

ibid.

ibid.

ibido

59

ibid.

11. 49

38,39

Afler Indicus,

Afragalits Baticus,

Atriplex portulacoides,

Averrbio bilimbi,

Avicennia tomentofa,

Ayçua,

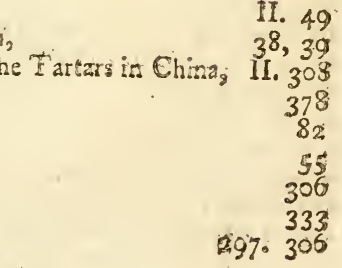

हैं.

$B^{\text {Accharis Irdicd, }}$ Backea fruiefcerss, Baliftes Cbirunfis, 


\section{I $\mathrm{N} D \mathrm{D} \quad \mathrm{E}$.}

Baliftes monoceros,

Bamboo reed, fee Arundo Bambos.

\section{Jcriptus,}

- roots, fee Afia.

Banca, a large Ifland near Sumatra, $\quad 164$

Banchall,

Banians,

Bantam, point of,

- queen of,

Barbers in China,

Barleria criftata,

Bartramia Indica,

Bafella rubra,

Batavia, capital of Java,

Bats?

162

160

230

362

376

II. 12

I6I

Beans, early growth of,

Bellis annua,

Benjamin, or Benzoin, a gum,

Befant'yes, fee Holothuria phyfalis.

Beta valgaris,

Bill of lading of the Swedian Indiaman,

Birds nefts,

Bifcutella didyma,

Blatta orientalis,

Blechnum occidentale,

Blindnefs of the Chinefe,

Bocea tiger,

Boletus caulefcens,

Bonnet fih, or Bonito, fee Scomber pelamis.

Bonzes,

240. 286

Booby, fee Pelecanus pifcator.

Books,

Borax, 


\section{$\begin{array}{lllll}I & N & D & E & X\end{array}$}

Berrago officinalis,

Bottle gourds, fee Cucurbita lagenaria.

Bramins,

Brandy, Chinefe,

Brafjica Chinenfos,

Briza elegans,

- media,

Bryonia cordifolia,

II. 180 315 II. 6 83 374 20 $33^{1} \cdot 3^{84}$ Buprefis maxima (gigantea Linn.) Burnet, fee Poterium. Buxoides aculeata, Byfus candelaris, $6 t$

c.

Acalia incana, Cactus Opuntia,

378 Cadiz, bay of.

- city of,

- exchange of,

- garden fruits fold there,

- houfes in,

- inhabitants of,

- miol'ya, a landing place,

- public buildings of,

Calamus rotang,

Calendula officinalis,

Calla Favanica,

Callvanfes, fee Dolichos Sinonfiso

Cambogia or Gamboge,

Camellia Faponica,

Camphire,

Cana, fee Arundo donax.

Canaria, the chief of the Canary Intands,

Canary Birds, fee Fringilla Canaria.

- Inands,

Cancer adfcenfionis,
B b 3 


\section{$I N D E \cdot$}

Canter arenarius,

Chinenfis,

II. $2: 9$

182

- eremita,

II. 52

II. II 6

oryza,

pelagicus,

Cangrejo, fee Sepia loligo.

357

II. 115

Canibas, an ine,

II. 1258

Canis aureus, the Jackcall,

330

Canna Indica,

Cantharis Chinenfis, fee Lampyris Cbininjis.

Canton, city of,

214

ibid.

Cape Pigeons, fee Procellarig Capen/is.

Cape Vincent, a promontory in Portugal,

capficum frutefens,

Earabus totus niger,

Qardillos, fee Cynara Jcolymus,

Carduus Syriacus,

8

18. 209

$6 \mathrm{~s}$

Garex coejpitofa,

Carpefiùn abrotanoides,

Caryeto urens,

Cafaguillas, a Spanifh drefs,

Gaffia procumbens,

Jopbera?

Cafida cinerea,

nigra, oblonga,

Caffytha filiformis,

Catefbea Favarisa,

$33^{\circ}$

359

337

395

139

Celojza argentea,

Cr.utata,

Gentaurea pullata, Sphacocepbale,

Cerafitum vifcofum,

Cerbera manghas,

Lerinto major,

Grvus (Javgriou?? 


\section{I $N$ D E X.}

Chamarops bumilis,

Chatodon faxatilis,

Cheiranthus cheiri,

incanus,

trilobus,

bybridum,

China, agriculture of,

- fertility of,

- populoufnefs of,

- religion of,

- rice-fields of,

- root, fee Smilax Cbina.

II. 273

II. $27 \mathrm{I}$

272

278

1I. 278

- foil of,

weather of,

Chinefe,

II. 278

II. 282

266

267

270

II. 242

of women,

- mercantile genius of,

Chiton lave, paintings,

marginibus dorfi spinofis,

Chryfanthemum coronarium,

1I. 60

Indicum,

Cicada Cbinenfis, Segetum,

Cinrabar,

Ciftus fumana,

birtus,

- Jalicifolius, falvifolius,

- tuberaria,

Citrus aurantium,

- decumane,

- Sinenfis, 


\section{N D E X.}

Clerodendron fortunatum,

Clupea my/us,

- tbriffa,

- tropica,

Clypeola jontblajpi,

Coccinella quadripufulata,

- Jeptempunctata,

Columba turtur,

Columnsa Chinenfis,

Commelina Chinenfis,

Comprádor, comminis,

Conferva bulbofa,

Conojito, fee Fumaria officinalis.

Convallaria Chinenfis,

Convolvolus althaoides,

II. 26

II. 103

$3^{68}$

64. 359

I5

371

393 ibid.

- batatas,

- bederaceus,

3II

326

376

139

313

Conus (Cbinenjos),

Conyza Cbinenfos,

birfuta,

374

70

Copper,

Cordia myxa,

Cork tree, fee 2usercus Juber.

Coronilla juncea,

Corrigiola littoralis,

Corypba umbraculifera,

Coryphana equifclis, Dorado,

Coftus dulcis, bippurus, Dolphin,

Cottons,

Cotyledon umbilicus,

11. $5^{243}$

Cratogus oxyacantha,

II. 58

II. 118

117. II. 117

259

241

20

82

Crepis 


\section{N D E X,}

Crepis barbata,

- fretida,

Crinum Afraticum,

\begin{tabular}{lr} 
Crithmum maritimum, Samphire, & 43 \\
\hline
\end{tabular}

Crocus bulbocodium,

Crotolaria juncea,

Croton Sebiferum,

Cryptanthus Chinenfis,

Cucurbita lagenaria,

345

150

pepo,

Cuprefus Sempervirens,

ibid.

Curcuma Chinen/is,

18

Cycas circinnalis,

Cynara bumilis,

329

259

74

Scolymus,

Cynoglofum cheirifolium,

Cynofurus Egyptius,

$5 \mathrm{r}$

Cyperus dichotomus,

376

baspan,

$37 \mathrm{I}$

376

378

odoratus,

Cyprinus Cantonenfis,

361

- pelagicus,

II. II3

D.

D Anifh Ifland, in the river Tiger, Daphne Gnidium,

Datchin, Indica,

Delpbinus Cbinenfos,

Orca, Grampus,

Dhociena, Porpeffe,

Dermefles, fubrotunda atra,

Diomedea Adfcenfionis,

Disulans, Albatros,

Diofcorea alata, Yams,

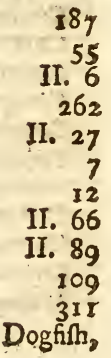




\section{N D E X.}

Dogfifh, greater, fee Squalus canicula. Dolichos maximus fcandens,

Dolphin, fee Coryphiena hippurus.

Dorado, fee Coryphana equifelis.

Doronicum bellidiaftrum,

Drácena ferrea,

Ducks, hatched in China,

Dunkirk,

Dwarf-mallow, fee Malva rotundifolia.

Dyers,

E.

FBony,

Es Echeneis remoras

Eebium Creticum,

'Échinops ritro,

74

Elephants, docility of,

59

gratitude of,

Eimberiza familiaris,

Epidendron amabile,

Eriocandon fexangulare,

Erythrina corallodendron.

II. 213

II. 198

157

II. 50

II. 15

387

Evolvulus alfmoides,

Eupborbia efula,

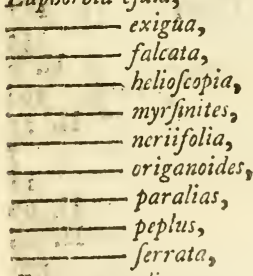

E.roscetus volitons,

14 I

392

60

ibid.

ibid.

47

60

II. 98

42

60

84

90

Factory 


\section{N D E X.}

F.

FActory at Canton,

F Falkenberg, a town in Sweden,

Fay-ye, fee Gobius pectinirofris.

Fayal, one of the Azores,

Fdau-fu,

Fennel, fee Anetbum.

Feol harbour in the Gothenburgh rocks,

Ferro, one of the Canary Iflands,

II. 120

2.18. 305

Fiador,

Ficus Indica,

Fifhery, in China,

Flagellaria Indica,

Flying finh, fee Exoccetus,

Foroe Inands telonging to Denmark,

Fortaventura, one of the Canary Inands,

Frederick-Henry, a hidden rock,

215. 381. II. I78.

$8^{2}$

Erench Ifland, in China,

Fringilla Canaria,

Fritillaria meleagris,

Frutex baccis albis,

Fucus divaricatus,

- lendigerus,

- maximus,

mujcoides,

- natans,

veficulofus,

Fumaria officinalis, Fumitory,

Funchal, a town and port in Madeira,

- ladies of,

Fu-yenn,

II. 317
II. 59

$2 \pi$

6
87

II. 44 .

347

18

83

II. 122 .

II. 99

II. 73

II. 99

II. 109

II. 122

55

II. 160 .

II. 162

216

G.

G Algant,

Galium aparine,

Gam-boge, or Gum-gutta,

256.

55
260

Games, 


\section{I $N \quad D \quad E \quad X$.}

Games, Chinefe,

Gamon, fee Afphodelus ramofus.

Gannets, fee Pelecanus bajfanus.

Genifa Anglica,

Gentoos, or Malabarians, at Suratte,

78

II. 177

- manners of,

II. 180

women of, their women's drefs,

Gerardia glutinofa,

II. 178

II. 186

Geranium cicutarium,

370

56

- gruinum,

66

- molle,

Ginfeng, fee Panax quinquefolium.

58

Gnao, fee Nymphaa nelumbo.

Gobius eleotris,

II. 32

- niger,

201

- peltinirofris,

200

Gold,

II. 102

Goldfiniths,

243

226

Gomora, one of the Canary Inlands,

87

Gomphrena globofa,

209

Goofe grafs, fee Galium aparine.

Godypium herbaceum,

Gothenburgh, a Swedinh town, and harbour for 349 dia hips,

Gracula religioja,

Grampus, lee Delphinus orca.

Granate mountain, in Spain,

Gratiola virginianoides,

Grilleria, cage for locufts,

Grillos, Spanifh locults, kept in cages,

Gryllus viridis, Whom-ma,

Guayava, fee Pfidium Guajava.

Guettarda speciofa, 


\section{N D E X.}

Gulls, herring, fee Larus fufcus.

Gungung,

186,187

H.

$\mathrm{H}^{\text {Appa, or Hoppo, }}$

H Hatters in China,

2:5. 359

Hedera belix,

Hedyotis herbacea,

Hedyfarum biarticulatum,

235

70

II. 4

coronarium,

Gangeticum,

378

330

354

lagopodioides,

346

- maculatum,

II. 8

- pulchellum,

- Ryracifolium,

374

II. 8

- trifiorum,

353

374

Heracleum jphondylium,

82

Hernandia fonora,

Hibifcus ficulneus,

mutabilis,

II. 63
328
II. 20

populneus,

Higuera del inferno, fee Ricinus communis.

II. 52

Hippobofca,

nigra,

Hippocrepis comofa,

129

II. 97

67

Hirundo rufitica,

95

Ho-a-khe,

Holcus latifolius,

Holly, fee Ilex aquifolium,

232

II. 8

Holotburia phyfalis,

Hoopoe, fee Upupa epops.

II. 74

Humulus lupulus,

Hußbandry, honoured in China,

336

Hyacintlous monftrofus, 


\section{N D E X.}

Hvacinthus ferotinus,

Hyoferis bedypnois,

- radiata,

rhagadioloides,

Hyofyamus albus,

Hypericum Chinenfe,

Hypnum Gavanenfe,

Hypocharis maculata,

56

75

ibid.

ibid.

83

11. 2

11. 49

82

$59^{\circ}$

1. $\mathrm{J}$.

Ackall, fee Canis astreus.

Japanners,

Jafmine fphinx, fee Sphinx atropos.

Fafininum Azoreum,

Java, Great, one of the Sonda Iffes,

II. 51

229

- head, a promontory on Java,

Little, or Baly, an Ifle near Great Java, 160

- monkies, fee Simia aygula.

- fparrows, fee Loxia oryzizora.

Ilex aquifolium,

Illecebrum paronycbia,

Impatiens balfamina,

Chinenfis,

Indigo,

Indigofera tinctoria,

Ink, Indian,

Joanna, or St. Joanna, an Iffe near Madagafcar,

II. 166

Joiners in China,

Ipomica quamoclit,

Iris Xiphium,

Iron tree, fee Dracana ferrea.

226

Jfchamum ariflatzm,

muticum,

IHa, a town in Spain,

Inands, feven, near Java,

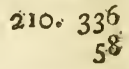




\section{I $N$ D E. X,}

Funcus acutus,

Tungermannia Chinenfis,

Junks,

-7uffea repens,

Fufticia procumbens,

- purpurea,

Ixora coccinea,

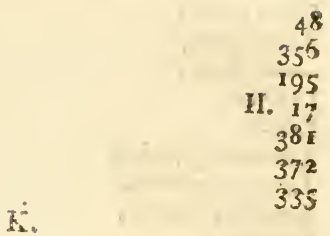

K Amm-katt,

I. Kann, fee Katty.

306

Ka-o-lin,

$\mathrm{Kas}$,

Katong qua,

Katty,

Kay-in,

Kilong,

Kitchen-gardens of the Chinefe,

Kobi,

Krakatoa, an IIand near Java,

Kulier,

$23^{2}$

202

374

262

374

220

II. 298

तुर

I3

213

L.

I Aan-fa,

1 Lacerta Chinenfiss,

Lack-tao,

so5. II. 67

Laholm, a town in Sweden,

Lai, fee Kas.

304

3

Lamium amplexicaule,

Lampyris Chinenfis,

Lancerota, one of the Canary Ifiands,

Lanfa, or Leenfa,

Lang-an,

Language, Chinefe,

Lanius fchach,

Lantoa, an Ine in the Chinefe fear.

$5^{8}$

36.

87

209

309

II. 237

367

174

Lapis 


\section{I $\mathrm{N} D \mathrm{D} \quad \mathrm{X}$.}

Lapis lazuli,

Larus canus,

fufcus,

Lat-yee,

Latt-fa,

Lavendula foechas,

Laurus camphora,

Lawfonia inermis, ibid.

9

308

II. 6

Laytang,

66

Lead,

Lemt'yes, fmall lemons, fee Citrus medica:

Lemur catta,

253

354

262

Lepas anatifera,

Leucojum autumnale,

Ley-kao,

Libellula Chinenfis,

Licben Chinenfis,

244

II. 168

121

67

377

$3^{61}$

171

$35^{6}$

- criftatus, .

51

378

II. $5^{2}$

marinus,

20

- parietinus,

59

- pulverulentus,

II. 49

roccella,

Lingen, an Ine near Sumatra,

10

II. 43

Ling-kamm, or Leng-ka,

305

178

Linting, an Ine in the Chinefe rea,

Literature, Chinefe,

277

Spanifh,

Lobelia Plumierii,

28

Lobelia Zeylanica,

II. 57

39 I

Locufts, Chinefe,

Lopbius bifrio,

Lotus cytifoides,

Loxia cardinalis, 


\section{N D E X.}

Loxia oryzivora, violacea,

Lucipara, an Inand near Sumatra,

Lupinus albus,

- hirfutus,

luteus,

varius,

Lycium barbarum,

Europaum,

Lycopodium cernuum,

Lycopfis veficaria,

M Acao, a Portuguefe town in China, Mace,

Madagafcar,

Madeira,

Magpies, grey-fpotted Chinefe,

Mabie, a French fettlement on the coaft of

Malabar,

Mahometans at Suratte,

Malabarians, or Gentoos,

112

377

Malmucks,

Malva Mauritiana,

II. 211

II. 184

II. 177

108

- rotundifolia,

Mammea Afiatica,

Man of war, fee Pelecanus Aquilus.

Mandarin,

fifh,

II. $\begin{array}{r}47 \\ 62\end{array}$

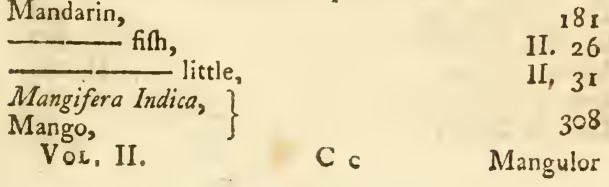




\section{I $N \quad D \quad E \quad X$.}

Mangulor town, on the coaft of Malabar, II. 209 Maranta galanga,

Marrubium vulgare, Matricaria cbamomela,

Mayota,

Medicago polymorpha, Melaftiona octandra,

Melia parafitica,

Malabarica,

Melö̈ majalis,

- varicgata,

Memecylon capitellatum,

Mercurialis annua,

Merops viridis, tomentofa,

Mes, fee Mace.

Micbelia champacca,

Mill beetles, fee Blatta orientalis.

256

II. 166

56
66
50

Millepora,

Limofa Cbinenfis,

Mintan, Farnejisna,

Mirablis oclora:a,

Mistilla,

Milluso pentapbyilla,

Monarda Cbinenfis,

Monopin, a mountain on the ine of Banca,

Monfoons,

Mnquaifa,

Morinda citrifolin,

- nmbelluta,

Mother of peirl,

34 I

354

II. 63

64

84

140

45

73

147

I 48

Mulec, ufed in Spain,

375

326

Minfa paradifaca, plantain,

Mufca niviea,

vuigatifima,

II. 166

387

39 I

I0 4

II. 42

209

JI. 56

$3^{6} 3$

265

$3^{5}$

I 5 I, 308

II. 97 ivid.

Mufick, Malabarian, 


\section{I $N$ D $E$ X.}

Murk,

Mufaenda frondofa,

Muttard, oriental,

Myojotis apula,

N.

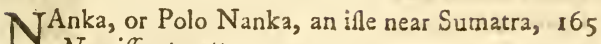
Narcifus tazetta,

Nardus articulata, 209

Nauclea orientalis, 346

Neriun oleander,

New Bay, in Java, oppofite New Inand,

- Ifland, between Java and Sumatra,

44

I 32

Nicotiana paniculata,

I 3 I

150

Northcaper, fee Delpbinus orca.

Nyciantbes birfuta,

Nymphcea nelumbo,

\section{O.}

Cimum gratifimum,

Oldenlandia umbellata,

Olea Europea, the olive tree,

Onifcus afilus,

Onoclea fenfibilis,

Ononis repens,

Opbioglofum fcandens,

Opium ufed by the Chinefe,

Uphrys infectifera $\beta$. arachnites,

376

386

15

65

142. 271

42

375

II. 247

II. $26 \mathrm{I}$

72

75

307

61

Orchis fufcefiens,

Origanum C'reticum,

Ornitbogaium umbellatum. 


\section{N D E X.}

Ornithopus comprefJus,

Orobanche major,

Orfelle, fee Lichen roccella.

$$
\begin{gathered}
67 \\
78 \\
\text { ibid. }
\end{gathered}
$$

Oryza Sativa,

Ofbeckia Chinenfis,

Oxalis corniculata,

Oyfters,

350. 254

342,343

II. $3^{30}$

\section{P.}

PAckfanny, fee, Albula Chinenfis.

Pack-la, Chinefe olives,

Pagodas,

Palankin,

Palma, a Canary Inand,

Palmetto, fee Chamarops.

Panax quinquefolium, Ginfeng,

309

238. II. 231

$2: 8$

87

Panicum alopecuroideum,

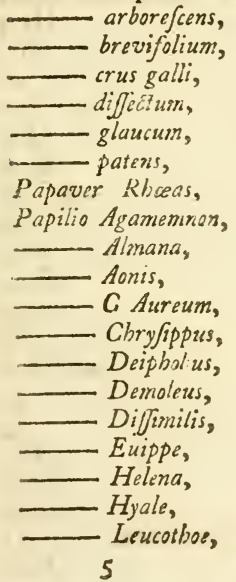

222

375

330

346

59

346

374

346

.56

332

ibid.

ibid.

ibid.

ibid.

$33^{x}$

332

331

$33^{2}$

331

or

332
Papilio 


\section{I $\mathrm{N} \quad \mathrm{D} \quad \mathrm{E} \quad \mathrm{X}$.}

Papilio Lintingenfis,

- Midamus,

Mineus,

332

ibid.

Orythia,

Pammon,

Pbiloctetes,

ibid.

ibid.

ibid.

ibid.

Plexippus,

65

Similis,

$33 \mathrm{I}$

Troilus,

332

ibid.

Parietaria Lufitanica,

Paron, ree Füncus acutus.

I9

Parthians, or Parfees, at Suratte,

Partridge, red-legged, fee Tetrao rufus.

Pajerina hirfuta,

Pafjifora coerulea,

II. $18_{3}$

Patiallingas, fmall merchant-hips in the Indies, I 59 Pavetta Indica,

Paulinia Afratica,

Pekul,

Pelecanus aquilus, man of war,

balfanus,

onocrotalus, pelican,

pifcator, booby,

Pepper Bay, in Java,

63

18

Perca Adfcenfionis,

Chinenfis,

Periploca Graca,

II. $5 \mathrm{I}$

II. 9

262

90. II. 87

II. $7 \mathrm{r}$

II. 87

90. 127

132

II. 95

II. 25

$33^{6}$

Petun-tfé,

232

Pbaëton atbereus, tropic-bird,

Phalana atlas,

Phlomis purpurea,

Phyllanthus Niuri,

Pbysalis,

Phytolacca Favanica,

Pisdra Blanca, a rock in the Chinefe fea,

90. II. 85

330

II. 25

57

II. 59

172

Piedra 


\section{N D E X.}

- Piedra del Puerco,

Pinang,

Pinus finea, Spanioh Pine,

Piper betle,

Piffacia lentifcus,

Plantago coronopus,

Plantain tree and fruit, fee Mufa paradifraca.

Plays, Chinefe,

Pleafure-gardens of the Chinefe,

Poa angufitolia,

Cbinenfis,

tenella,

Policy of the Chinefe,

Polo-trya, an ifle near Sumatra,

Polygala cilinta,

Polygonum barbatum,

Chinense,

II. 305

$37^{8}$

330

ibid.

II. 252

166

356

353

330

orientale,

Polypodium Barometz,

Populus alba,

Porcellane,

Porcos, rocks near Cadiz,

Porpeft, fee Delphinus phocana.

Porro Santo, a Canary inle,

Portulaca oleracea,

Poterium fanguiforba,

Prince In and, in the Straights of Sonda,

87

II. 99

Proas, Javanefe boats fo called,

Procellaria aguinoctialis, form-finch,

$P$ fitium guajava,

PJittacus Alexandri, 


\section{N D E X.}

Pfittacus garrulus,

Pteris Semipinnata,

Puerto de Santa Maria, a town near Cadiz,

- Real, a town near Cadiz, 9

10

Punica granatum, pomegranate,

Q.

Uaifa,

Quail, Chinefe, fee Tetrao Cbinenfis.

II. 14 Qieda, a town in the Straights of Malacca, II. 216 Quercus fuber, cork-tree,

Quickfilver,

37

245

R.

$R^{\text {Ana Chinenfis, }}$

$R$ Ronunculus aquatilis,

299

bulbofus,
Ravens, Chinefe, with white necks,
Refeda glauca,
Retamas, fee Spartium monofpermum.

mulbofus,
Ravens, Chinefe, with white necks,
Refeda glauca,
Retamas, fee Spartium monofpermum.

mulbofus,
Ravens, Chinefe, with white necks,
Refeda glauca,
Retamas, fee Spartium monofpermum.

mulbofus,
Ravens, Chinefe, with white necks,
Refeda glauca,
Retamas, fee Spartium monofpermum.

mulbofus,
Ravens, Chinefe, with white necks,
Refeda glauca,
Retamas, fee Spartium monofpermum.

mulbofus,
Ravens, Chinefe, with white necks,
Refeda glauca,
Retamas, fee Spartium monofpermum.

59
83

377

83

Rhamnus lineatus,

- anopolia,

Rhubarb,

254

Rbus Chinenfe,

375

Rice,

254

Ricinus communis,

Riff, a Swedim harbour in the Gothenburgh rocks, 2

Ro, fee Cifus falvifolius.

Robbers in China,

Rofemary, abundant in Spain,

$3^{22}$

Rofewood,

33

228

Rota, a town near Cadiz,

$\mathrm{C} \mathrm{C}_{4}$

10

Ruivs 


\section{N D $\mathrm{D} \quad \mathrm{E} \quad \mathrm{X}$.}

Rubus fruticofus,

Ruellia crifpa,

ringens,
Rumex acetofa,
Ruta graveolens,

S.

SAcharum officinale,

Sagittaria bulbis oblongis,

Sagu, or fago,

Saintfoin, fee Hedyfarum coronarium.

Salicornia fruticico $a$,

Saljola fruticoja,

Saltamatos, large locufts,

Salvia verbenaca,

Sambucus nigra,

Samm-nimm, fee Averrboa bilimbi.

Sampanes,

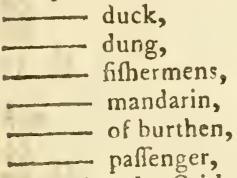

190

194

196

193

395

$\sqrt{94}$

190

Samphire, fee Critbmum.

Samfu,

Sanguis draconis,

Santa Cruz, a town on Teneriffe,

Santal wood, or Santalum album,

Satureja capitata,

Scarabaus bilobus,

- Sacer,

_- typhoeus,

Schoenus mucronatus,

235. 315

259

88

260

66

65

Scilla Peruviana, 


\section{N D E X.}

Scilly Ifands,

Scirpus Chinenfis,

Scolopendra pedibus utrinque viginti,

Scomber glaucus,

- pelamis, bonito,

Scorpiurus falcata,

Scoter, fee Anas nigra.

Scrophularia Sambucifolia,

Scutellaria Indica,

Scyllaa pelagica,

Sea purflane, fee Atriplex portulacoides.

Sect of Tao-tra, Fo or Foé, $\}$ fee China (religion of).

Selleria, fee Tophus.

Sempervivum arboreum,

Senecio communis,

- divaricatus,

Sepia loligo,

Serapias lingua,

Sertularia confervaformis,

Shaddock, ree Citrus decumana.

II. 30

Shaupann,

Sherardia arvenfis,

Shoemakers in China,

228

59

II. 99

Sida cordifolia,

- Spinofa,

Sigefbeckia orientalis,

141

Silene conoidea,

pendula,

Silk, raw,

- Atuffs,

Simia aygula,

Sifymbrium irio, 


\section{I $\quad \mathrm{N} \quad \mathrm{D}^{\prime} \quad \mathrm{E} \quad \mathrm{X}$ :}

Sifymbrium fylvefre,

Sitta Chinenfis,

Siuu, Chinefe truffles,

II. 12

Smilax aspera, China,

- Saffaparilla,

Snail-trefoil, fee Medicago.

Solanum diphyllum,

- Indicum,

328

nigrum,

Solidago Chinen/is,

Sonchus oleraceus,

Sophora alopecuroides,

393

Sovaja, a kind of corn,

Soya, fee Dolichos Joya.

- fee Hedyfarum coronarium.

Spartium junceum,

monospermum,

- Spinofum,

Sparto, fee Stipa tenacifjma.

Sparus Chinenjis,

nobilis,

II. $3 \mathrm{I}$

II. 26

- Spinus,

Spergula pentandra,

II. 53

69

Spermacoce verticillata,

355

Sphagnum paluftre,

sphinx atropos,

Spices,

Squalus adfcenfionis,

I33

260

II. 9 I

100

catulus,

II 4

St. Helena, an Englifh ifle in the Atlantick, II. 76

St. Foleph's flower, fee Allium triquetrum.

St. Lucar, a town near Puerto de Santa Maria,

St. Paul and Amfterdam, two rocks in the Indian fea,

St. Pedro, a rock on the coaft of Spain, 


\section{N D E X X}

St. Sebaftian, a caftle near Cadiz,

Stachys arvenfis,

Sirta,

Statice armeria,

Stellaria arenaria,

Sterna nigra,

Sicklack,

Stipa tenacifima,

Storm-finch, fee Procellaria aquinoctialis.

Sugar,

Sumatra, one of the Sonda Iflands,

Sunfpurge, fee Euphorbia beliofcopia.

Suratte, a town on the coaft or Malabar,

- cattle of,

- inhabitants of, itreets of,

- trade of,

weights and coins of,

Swallow, fee Hirundo rufitica.

Swine, Chinefe,

Syan pan,

Syngnathus argenteus, pelugicus,

II. 170

II. 173

II. 177

II. 175

II. 194

II. 195

II. 309 265

II. 107

II. 113

T.

TAle,

$\left.\begin{array}{l}\text { Tamarinds, } \\ \text { Tamarindus Indica, }\end{array}\right\}$

262

309

Tanacetum balfamita,

Tan-nodo, fee Gobius niger.

Targionia bypophylla,

Tayfun, ftorm fo called by the Chinefi,

55

Taylors in China,

Tea, 


\section{I $\mathrm{N} \quad \mathrm{D} \quad \mathrm{E} \quad \mathrm{X}$.}

Tea, brown,

gobe,

250

honam,

247

hyfon,

250

kuli,

247

linkifam,

249

ibid.

- padre futchong,

250

ibid.

finglo,

248

ibid.

tao-kionn,

250

Tel, fee Tale.

Tenebrio muricatus,

Teneriffe, one of the Canary ifles, Pico of,

Terraces, hills divided into,

Tefudo mydas,
Tetradapa Javanorum, fee Erythrina corallodendron.

Tetrao Cbinenjes, Chinefe quail,

- rufus, red-legged partridge,

65

87

88

II. 290

II. 80.89

Tetrodon ocellatus,

Teucrium fruticans,

303

18

$3^{6} 4$

67

55

Thlaspi burfa paftoris,

Thuya orientalis,

Tiapp, a paffport,

houfes, cuftomhoufes in China,

Tillea procumbens,

Tin,

Tintenaque, or tutanego,

Tobacco, dangerous to import into Spain, fee Nicotiana paniculata.

Tombs, magnificent,

II. 175

Tophus, particulis teftaceis, argillâ \& arenâ cu\&dunatus,

Torenia Afiatica, 


\section{I $\mathrm{N} \quad \mathrm{D}: \mathrm{E}$ X.}

Torvicho, or tomillo, fee Paferina hirfuta. Tracbinus Adfcenfionis,

Tragopogon Dalechampii,

Trapa natans,

Trees, Chinefe, culture of,

Trichomanes Chinense,

Tropic bird, fee Phaëton athereus.

Trumpet weed,

Tfang-to, or tfang-tack,

Tunny, fee Scomber thynnuis.

Turdus canorus, or

Turdus Chinenfis,

II. 96

II. 305

357

Turf, conftituent parts of,

- method of digging it in Halland,

qualities of that in Halland,

Two Brothers, ines near Java,

II. 73

210

\section{U. V.}

7 Aleriana Chinenfis,

Vargoe Hoala, a Swedin harbour,

II. $12 \mathrm{I}$

Verbafcum O/beckii,

Verbena nodifora,

Verbefina calendulacea,

Chinenfis,

- lavenia,

Veronica agreftis,

- anagallis aquatica,

Vices of the Chinefe,

Vicia lutea,

Vientaro, fee Cerbera manghas,

353

5
3,4
4
362

5
3,4
4
362

$V$ inca major,

$V i f$ cum baccis rubentibus,

Vitex negundo,

trifolia,

5 I

2

68

$3^{6} 3$

356

393

141

356

56

74

II. $23^{8}$

57

$13^{8}$

330

$x 40$

Ulex 


\section{N D E X.}

Ulex Europaus,

Ulva lactuca,

Umbrellos,

Volckameria inermis,

Upupa epops,

Urena Chinenfis,

lobata,

- procumbens,

finuata,

Urtica dioica,

urens,

Utricularia bifida,

\section{W.}

W Ake Robin, fee Arum maculatim.

W'altheria Indica,

Wampu, a town in China,

Watches,

Welcome Bay, in Java,

Whomma, Chinefe locufts,

Wo-aw-fiong, fee Bonzes.

\section{X.}

Erez de la Frontera, a town in Spain,

Xrom whence the Xerez wine or fherry is brought,

\section{Y.}

YAms, fee Diofcorea alala.

Yanfam or Yaniom, fẹe Panax guinquefolium. Yedra, fee Hedera helix. 


\section{I $N \quad D \quad E \quad X$.}

Yerva de Santa Maria, fee Tanacetum balfamita. mala, fee Nerium oleander.

\section{$z$.}

2 Anthoxylum trifoliatum, 


\title{
E R R A T A r
}

\author{
V O L U M E I.
}

Pag. 2. line ult. for Holland, read Halland.

3. I. for was not common, read was common.

7. for Holland, read Halland.

12. 7. for $\mathrm{Cafa}$ guillas, read $\mathrm{Cafaquillas.}$

96. ult. for we paffed in, read we paffed under the fun, in.

307. 23. and ult. for ocres, read oeres.

145: antepenult, for wrought, read written.

146. penult. for which gives a luftre to their complexion, read which makes their hair look gloffy.

379. 22. for and kept near the fhip (or Bancihal), read and kept either near the hip or near the Bancihal.

184. 38. for Centurion, read Anfon.

195. I9. for three mace peckuls, read three mace, the peckul.

223. 17. for Jartona, read Jartoux.

246 . 3,4. for Cochin, China, reod Cochin-China.

262. 6. for ocre, read ocre.

262. 7. for ocre, read oere.

266. 2. for 20 , read 10 .

301. 15. for ocre, read oere.

362. 9. for Ablieyfa, read Abkeyfa.

371. 4. dele TAE.X.

V O L U M E II.

115.

121.

123.

182 .

187.

388. 2. for tisen we, read then they.

23. for brachiperus, read brachyurus.

1. for Lhin. read Chin.

2. for ftatia, read ftatice.

3. for mafiota, read mayota.

7. muft, dele tbe comma, and read mufk.

penult. for put our heads on their left fhoulder, read put their heads on the left poulder of their friends.

for ours, read thole of their friends.

2. for our, read their.

392. penult. for half a quarter, read half a quarter of a yard.

194. 6. for Camboya, agates, read Camboya-agates.

200. 4. for articularius, read cubicularius, or Alexandri.

204. 10. for all the factories belonging to the Englifh in the Ealt Indies have chaplains, read but a clergyman they think quite unnecefiary.

205. 25. for worked on with faddles, read worked with paddles.

206. I. for rails, read nails.

246. 18, 19. for finews of deer, read itag's pizzles.

aj8. I1. for are, read are wound. 


New York Botanical Garden Library DS708 .081771 v.2

Osbeck, Per/A voyage to China and the Ea

${ }_{3} 5185000742740$ 
